\title{
European Constitutionalism and the German Basic Law
}

\author{
Dieter Grimm, Mattias Wendel and Tobias Reinbacher
}

\begin{abstract}
The German Basic Law of 1949, intended to be the counter-authoritarian answer to the atrocities committed during the National Socialist regime, enshrines a distinctive and widely followed model of constitutionalism, entrenching institutions and procedures for the protection of fundamental rights. The Constitution begins with provisions on human dignity and inalienable human rights. It determines the unamendable substantive core of the constitutional order. A pre-eminent role is held by the German Federal Constitutional Court (FCC), and its judgments are taken into account early in the process of drafting legislation. The report outlines the extensive amendments that have been made to the Constitution to allow for EU and inter-
\end{abstract}

\footnotetext{
Dieter Grimm is Professor of Public Law, Humboldt University Berlin, and Visiting Professor of Law and Peter and Patricia Gruber Fellow in Global Justice, Yale Law School; former Justice, Federal Constitutional Court of Germany; former Rector of the Wissenschaftskolleg zu Berlin (Institute for Advanced Study). e-mail: grimm@wiko-berlin.de.

Mattias Wendel is Professor of Public Law, International Law, EU Law and Comparative Law, Bielefeld University. e-mail: mattias.wendel@uni-bielefeld.de.

Tobias Reinbacher is Professor of Criminal Law and Criminal Procedure, Julius-Maximilians University of Würzburg. e-mail: tobias.reinbacher@jura.uni-wuerzburg.de.

Dieter Grimm wrote Part Two and Part Three, with the exception of Sect. 2.3, which was written by Tobias Reinbacher. Mattias Wendel wrote Part One. All authors are solely responsible for the parts they have written.
}

The report was finalised by the end of 2015. All websites accessed 12 January 2016 .

D. Grimm (ه)

Humboldt University Berlin, Berlin, Germany

e-mail: grimm@wiko-berlin.de

D. Grimm

Wissenschaftskolleg zu Berlin (Institute for Advanced Study), Berlin, Germany

M. Wendel

Bielefeld University, Bielefeld, Germany

e-mail: mattias.wendel@uni-bielefeld.de

T. Reinbacher

Julius-Maximilians University of Würzburg, Würzburg, Germany

e-mail: tobias.reinbacher@jura.uni-wuerzburg.de

(C) The Author(s) 2019

A. Albi and S. Bardutzky (eds.), National Constitutions in European

and Global Governance: Democracy, Rights, the Rule of Law,

https://doi.org/10.1007/978-94-6265-273-6_10 
national co-operation. Both the Constitution and the Constitutional Court adhere to a Europe-friendly approach, albeit with limits. The FCC has delivered a considerable number of widely discussed constitutional judgments with regard to a broad range of EU measures, from the early Solange cases regarding fundamental rights to the more recent Data Retention, ESM Treaty and OMT cases, which are all summarised in the report. The extensive constitutional debates regarding the European Arrest Warrant system are also outlined. In the FCC case law on the euro crisis, a key theme is that financial liabilities ought to remain calculable, in order to preserve a link between the people and democratic representation through Parliament. More broadly, the report observes the way in which the constitutionalisation through EU Treaties of wide-ranging areas of regulation which are normally not found in constitutions has reduced democracy (the 'over-constitutionalisation' thesis developed by Dieter Grimm); a case is made for a revised approach. Regarding contested aspects of transnational law, there has been a constant concern regarding its effects on the social state.

Keywords The Constitution/Basic Law of Germany - Amendment of the Constitution in relation to EU and international co-operation - Euro-friendly interpretation and constitutional limits - German Federal Constitutional Court Inalienable human rights - Constitutional review statistics $\cdot$ Solange Data Retention Directive - European Arrest Warrant, extraditions, nulla poena sine lege, Judicial review and ordre public - ESM Treaty - OMT and calculability of financial liabilities - Democracy and parliamentary control over the budget Human dignity and a change of balancing in Omega - Constitutionalisation of EU and international law . Changing language of constitutionalism at the transnational level • Identity review - Unamendable core of the constitutional order

\section{Constitutional Amendments Regarding EU Membership}

\subsection{Constitutional Culture}

1.1.1 The German Basic Law of 1949 (Grundgesetz, hereinafter also GG) is a legally fully binding constitutional text at the top of the domestic hierarchy of norms, containing constitutional principles and rules that are generally enforceable in the courts. Its historical conditionality is twofold. ${ }^{1}$ First and foremost the Basic

\footnotetext{
${ }^{1}$ Cf. Dreier 2007, para. 6.
} 
Law was adopted after the fall of the National Socialist regime. It was intended to be the counter-authoritarian answer to the atrocities committed between 1933 and 1945. Secondly, the Basic Law stands in the tradition of the democratic Weimar Constitution, albeit differing significantly in several aspects in order to avoid the constitutional vulnerability and political instability of the latter. The denomination as 'Basic Law' symbolises the provisional character initially attributed to it, leaving open the possibility of a new constitutional order for an eventually unified Germany. However, in 1990 German reunification was put into effect at constitutional level without the adoption of a new constitution.

Despite its originally provisional character, the Basic Law can be described as one of the most important success stories of German post-war history. Not only has the Basic Law provided a normative framework for the effective protection of individual rights and stable political institutions, but there is also a high degree of identification among the citizens with its basic values, institutions and procedures a civic approach referred to as 'constitutional patriotism' (Verfassungspatriotismus) by Sternberger and Habermas. ${ }^{2}$ In contrast to constitutional systems in Europe such as in the UK, the Netherlands and the Nordic countries, the German constitutional system is particularly characterised by the eminent role of the German Federal Constitutional Court (Bundesverfassungsgericht hereinafter BVerfG), a powerful, but certainly not unquestioned, ${ }^{3}$ institution. The BVerfG is a court designed to adjudicate individual complaints on fundamental rights violations as well as disputes on inter-institutional and competence issues. It decides regularly on key questions of political life and holds a high reputation among the German population. Furthermore, the constitutional culture in Germany is characterised by a strong constitutional scholarship traced back, to this day, to the Weimar Republic. ${ }^{4}$

1.1.2 The substantial key elements and the rationale of the Basic Law lie in the protection of fundamental rights as well as the safeguarding of the core principles enshrined in Art. 20 of the Basic Law, namely the principles of democracy, federalism, separation of powers, the social state and the rule of law (Rechtsstaatsprinzip). While the latter can linguistically be translated by the term 'the rule of law', it should conceptually not be confounded with 'the rule of law' in the sense of the common law system (for the Rechtsstaatsprinzip, see in more detail Sect. 2.1.3). The BVerfG has played a central role in enforcing and spelling out these constitutional principles in legal practice. Regarding the fundamental rights in the Basic Law, the BVerfG does not only construe them in the sense of effective individual rights protecting the individual against public authority, but also interprets them as key principles shaping the legal order of Germany as a whole.

\footnotetext{
${ }^{2}$ Sternberger 1990, pp. 17-31; Habermas 1992, p. 642 et seq. For an analysis of the concept, see Müller 2010.

${ }^{3}$ See Jestaedt et al. 2011.

${ }^{4}$ For a 'genealogy' and the peculiarities of the German scholarship of constitutional law, see Schultze-Fielitz 2013.
} 
Furthermore, the BVerfG has played a major role as a guardian of the inter-institutional balance of powers and (political) minority rights.

\subsection{The EU in German Constitutional Law}

1.2.1 Germany is a founding member of the European Communities. Its determination to 'promote world peace as an equal partner in a united Europe' has been highlighted in the preamble of the Basic Law ever since its entry into force in 1949:

Preamble [since 1949] ${ }^{5}$

... Inspired by the determination to promote world peace as an equal partner in a united Europe, the German people, in the exercise of their constituent power, have adopted this Basic Law. ...

However, Germany's membership in the EU (and the former European Communities) was not specifically addressed in the operative part of the German Basic Law until 1992. In the previous decades Germany's membership in the EU was constitutionally based on Art. 24, a clause authorising the 'transfer of sovereign powers' (Übertragung von Hoheitsrechten) to international institutions by means of an ordinary statute of Parliament. Despite referring to international institutions in general, Art. 24 had in fact been drafted in 1948/49 with a view to a (future) process of European cooperation. ${ }^{6}$ In a comparative perspective, the clause was even described in 1948 by one of its drafters as a "very nice answer' ${ }^{7}$ to the preamble of the French constitution of 1946 (Fourth Republic), which enabled 'limitations' to national sovereignty in its paragraph $15 .{ }^{8}$ Although still in force as such, since 1992, Art. 24 no longer applies to EU affairs. The Article reads as follows:

Article 24 [Transfer of sovereign powers to international organisations i.a. - since 1949]

(1) The Federation may by a law transfer sovereign powers to international organisations.

Constitutional provisions specifically addressing Germany's membership in the EU (EU-related constitutional law) ${ }^{9}$ were introduced for the first time in December 1992 with regard to the Treaty of Maastricht. Major subsequent revisions took place in the course of the second reform of Germany's federalist system in 2006 and with

\footnotetext{
${ }^{5}$ Translation by Tomuschat, Currie and Kommers, available at the Website of the German Bundestag, https://www.bundestag.de/blob/284870/ce0d03414872b427e57fccb703634dcd/basic_ law-data.pdf.

${ }^{6}$ For the historical development, see Sommermann 2008, para. 5 et seq.

${ }^{7}$ Eberhard 1948, p. 70.

${ }^{8}$ The conception and practical importance of these clauses differ significantly, however.

${ }^{9}$ For the terminology, see Mayer and Wendel 2014, para. 1 et seq.
} 
regard to the Treaty of Lisbon in 2009. Furthermore, the sovereign debt crisis led to several amendments of the financial provisions in 2009 (see Sect. 1.2.3).

The key provision addressing Germany's membership in the EU today is the so-called integration clause (Integrationsklausel), laid down in Art. 23 of the German Basic Law. This provision was introduced in December 1992 with regard to the Treaty of Maastricht, was subsequently amended in 2006 with regard to the participation of the federal states (Länder) in EU affairs and extended in 2009 with a view to the subsidiarity control by national parliaments. It reads as follows:

Article 23 [European Union - introduced in 1992, para. (6) amended in 2006, para. (1a) introduced in 2009]

(1) With a view to establishing a united Europe, the Federal Republic of Germany shall participate in the development of the European Union that is committed to democratic, social and federal principles, to the rule of law, and to the principle of subsidiarity, and that guarantees a level of protection of basic rights essentially comparable to that afforded by this Basic Law. To this end the Federation may transfer sovereign powers by a law with the consent of the Bundesrat. The establishment of the European Union, as well as changes in its treaty foundations and comparable regulations that amend or supplement this Basic Law, or make such amendments or supplements possible, shall be subject to paragraphs (2) and (3) of Article 79.

(1a) The Bundestag and the Bundesrat shall have the right to bring an action before the Court of Justice of the European Union to challenge a legislative act of the European Union for infringing the principle of subsidiarity. The Bundestag is obliged to initiate such an action at the request of one fourth of its Members. By a statute requiring the consent of the Bundesrat, exceptions from the first clause of paragraph (2) of Article 42, and the first clause of paragraph (2) of Article 52, may be authorised for the exercise of the rights granted to the Bundestag and the Bundesrat under the contractual foundations of the European Union.

(2) The Bundestag and, through the Bundesrat, the Länder shall participate in matters concerning the European Union. The Federal Government shall keep the Bundestag and the Bundesrat informed, comprehensively and at the earliest possible time.

(3) Before participating in legislative acts of the European Union, the Federal Government shall provide the Bundestag with an opportunity to state its position. The Federal Government shall take the position of the Bundestag into account during the negotiations. Details shall be regulated by a law.

(4) The Bundesrat shall participate in the decision-making process of the Federation insofar as it would have been competent to do so in a comparable domestic matter, or insofar as the subject falls within the domestic competence of the Länder.

(5) Insofar as, in an area within the exclusive competence of the Federation, interests of the Länder are affected, and in other matters, insofar as the Federation has legislative power, the Federal Government shall take the position of the Bundesrat into account. To the extent that the legislative powers of the Länder, the structure of Land authorities, or Land administrative procedures are primarily affected, the position of the Bundesrat shall be given the greatest possible respect in determining the Federation's position consistent with the responsibility of the Federation for the nation as a whole. In matters that may result in increased expenditures or reduced revenues for the Federation, the consent of the Federal Government shall be required. 
(6) When legislative powers exclusive to the Länder concerning matters of school education, culture or broadcasting are primarily affected, the exercise of the rights belonging to the Federal Republic of Germany as a member state of the European Union shall be delegated by the Federation to a representative of the Länder designated by the Bundesrat. These rights shall be exercised with the participation of, and in coordination with, the Federal Government; their exercise shall be consistent with the responsibility of the Federation for the nation as a whole.

(7) Details regarding paragraphs (4) to (6) of this Article shall be regulated by a law requiring the consent of the Bundesrat.

Alongside the integration clause and the preamble, there are several stipulations addressing specific issues relating to Germany's membership in the EU. The most important ${ }^{10}$ are:

Article 16 [extradition i.a. - para. (2) cl. 2 introduced in 2000]

(2) No German may be extradited to a foreign country. The law may provide otherwise for extraditions to a member state of the European Union or to an international court, provided that the rule of law is observed.

Article 28 [participation of EU citizens in local elections i.a. - para. (1) cl. 3 introduced in 1992]

(1) ... In county and municipal elections, persons who possess citizenship in any member state of the European Community are also eligible to vote and to be elected in accord with European Community law. ...

Article 45 [parliamentary EU-Committee - introduced in 1992, cl. 3 added in 2009]

The Bundestag shall appoint a Committee on the Affairs of the European Union. It may authorise the committee to exercise the rights of the Bundestag under Art. 23 vis-à-vis the Federal Government. It may also empower it to exercise the rights granted to the Bundestag under the contractual foundations of the European Union.

Article 88 [Federal Bank \& European Central Bank - cl. 2 introduced in 1992]

The Federation shall establish a note-issuing and currency bank as the Federal Bank. Within the framework of the European Union, its responsibilities and powers may be transferred to the European Central Bank, which is independent and committed to the overriding goal of assuring price stability.

Article 109 [golden rule i.a. - introduced/amended in 2009]

(2) The Federation and the Länder shall perform jointly the obligations of the Federal Republic of Germany resulting from legal acts of the European Community for the maintenance of budgetary discipline pursuant to Article 104 of the Treaty Establishing the European Community and shall, within this framework, give due regard to the requirements of overall economic equilibrium.

\footnotetext{
${ }^{10}$ Further references to the EU or the former European Communities can be found in Art. 104a(6), Art. 106(1) No. 7, Art. 108(1), Art. 109(5) (financial and budgetary matters) and Art. 87d(1) (air transport administration).
} 
(3) The budgets of the Federation and the Länder shall in principle be balanced without revenue from credits. The Federation and Länder may introduce rules intended to take into account, symmetrically in times of upswing and downswing, the effects of market developments that deviate from normal conditions, as well as exceptions for natural disasters or unusual emergency situations beyond governmental control and substantially harmful to the state's financial capacity. For such exceptional regimes, a corresponding amortisation plan must be adopted. Details for the budget of the Federation shall be governed by Article 115 with the proviso that the first clause shall be deemed to be satisfied if revenue from credits does not exceed 0.35 percent in relation to the nominal gross domestic product. The Länder themselves shall regulate details for the budgets within the framework of their constitutional powers, the proviso being that the first clause shall only be deemed to be satisfied if no revenue from credits is admitted.

(5) Sanctions imposed by the European Community on the basis of the provisions of Article 104 of the Treaty Establishing the European Community in the interest of maintaining budgetary discipline, shall be borne by the Federation and the Länder at a ratio of 65 to 35 percent. In solidarity, the Länder as a whole shall bear 35 percent of the charges incumbent on the Länder according to the number of their inhabitants; 65 percent of the charges incumbent on the Länder shall be borne by the Länder according to their degree of causation. Details shall be regulated by a federal law which shall require the consent of the Bundesrat.

Alongside these stipulations expressly referring to EU affairs, several general articles play a key role for the constitutional foundations of Germany's membership in the EU. These provisions address key constitutional principles and have been part of the German Basic Law since 1949:

Article 1 [Human dignity, human rights - since 1949]

(1) Human dignity shall be inviolable. To respect and protect it shall be the duty of all state authority.

(2) The German people therefore acknowledge inviolable and inalienable human rights as the basis of every community, of peace and of justice in the world.

Article 20 [Basic constitutional principles - since 1949]

(1) The Federal Republic of Germany is a democratic and social federal state.

(2) All state authority is derived from the people. It shall be exercised by the people through elections and other votes and through specific legislative, executive and judicial bodies.

(3) The legislature shall be bound by the constitutional order, the executive and the judiciary by law and justice.

Article 38 [elections, right to vote - since 1949]

(1) Members of the German Bundestag shall be elected in general, direct, free, equal and secret elections. They shall be representatives of the whole people, not bound by orders or instructions, and responsible only to their conscience. 
Article 79 [constitutional revision, 'eternity clause' - since 1949]

(1) This Basic Law may be amended only by a law expressly amending or supplementing its text. ...

(2) Any such law shall be carried by two thirds of the Members of the Bundestag and two thirds of the votes of the Bundesrat.

(3) Amendments to this Basic Law affecting the division of the Federation into Länder, their participation on principle in the legislative process, or the principles laid down in Articles 1 and 20 shall be inadmissible.

Article 146 [Duration of the Basic Law - amended in 1990 in the context of Germany's reunification]

This Basic Law, which since the achievement of the unity and freedom of Germany applies to the entire German people, shall cease to apply on the day on which a constitution freely adopted by the German people takes effect.

Beyond the stipulations of positive constitutional law, the EU related jurisprudence of the German BVerfG has played an eminent role for the constitutional foundations of Germany's participation in the ongoing process of European integration, but also for the development of the jurisprudence in other EU Member States. The following figure among the most prominent leading cases: Solange I (1974), ${ }^{11}$ Eurocontrol I (1981), ${ }^{12}$ Solange II (1986), ${ }^{13}$ Treaty of Maastricht (1993), ${ }^{14}$ Banana Market (2000), ${ }^{15}$ European Arrest Warrant I (2005), ${ }^{16}$ Treaty of Lisbon (2009), ${ }^{17}$ Honeywell (2010), ${ }^{18}$ Data Retention (2010), ${ }^{19}$ Greece and EFSF (2011), ${ }^{20}$ Investment Allowance Act (2011), ${ }^{21}$ Five Percent Threshold EU Elections (2011), ${ }^{22}$ ESM \& Fiscal Compact - summary review (2012), ${ }^{23}$ OMT (2014) ${ }^{24}$ and

${ }^{11}$ BVerfG, case 2 BvL 52/71, Solange I, order of 29 May 1974, BVerfGE 37, 271.

${ }^{12}$ BVerfG, case 2 BvR 1107/77 et al., Eurocontrol I, order of 23 June 1981, BVerfGE 58, 1.

${ }^{13}$ BVerfG, case 2 BvR 197/83, Solange II, order of 22 Oct. 1986, BVerfGE 73, 339.

${ }^{14}$ BVerfG, case 2 BvR 2134, 2159/92, Treaty of Maastricht, judgment of 12 Oct. 1993, BVerfGE $89,155$.

${ }^{15}$ BVerfG, case 2 BvL 1/97, Banana Market, order of 7 June 2000, BVerfGE 102, 147.

${ }^{16}$ BVerfG, case 2 BvR 2236/04, European Arrest Warrant I, judgment of 18 July 2005, BVerfGE 113, 273.

${ }^{17}$ BVerfG, case 2 BvE 2/08 et al., Treaty of Lisbon, judgment of 30 June 2009, BVerfGE 123, 267.

${ }^{18}$ BVerfG, case 2 BvR 2661/06, Honeywell, order of 6 July 2010, BVerfGE 126, 286.

${ }^{19}$ BVerfG, case 1 BvR 256/08 et al., Data Retention, judgment of 2 Mar. 2010, BVerfGE 125, 260.

${ }^{20}$ BVerfG, case 2 BvR 987/10 et al., Greece \& EFSF, judgment of 7 Sept. 2011, BVerfGE 129, 124.

${ }^{21}$ BVerfG, case 1 BvL 3/08, Investment Allowance Act, order of 4 Oct. 2011, BVerfGE 129, 186.

${ }^{22}$ BVerfG, case 2 BvC 4/10, Five Percent Threshold EU Elections, judgment of 9 Nov. 2011, BVerfGE 129, 300.

${ }^{23}$ BVerfG, case 2 BvR 1390/12 et al., ESM \& TSCG - summary review, judgment of 12 Sept. 2012, BVerfGE 132, 195.

${ }^{24}$ BVerfG, case 2 BvR 2728/13 et al., OMT, order of 14 Jan. 2014, BVerfGE 134, 366. 
European Arrest Warrant II (2015). ${ }^{25}$ While the gist of these decisions will be treated below in the context of the respective questions, one should, as a start, distinguish between two lines of case law.

The first line of jurisprudence relates to the scenario of treaty reform. In this scenario the parliamentary Act approving the ratification of a European reform treaty (e.g. Treaty of Maastricht or Lisbon) or an international treaty substantially supplementing EU law (e.g. the Treaty Establishing the European Stability Mechanism Treaty (ESM Treaty) or the Treaty on Stability, Coordination and Governance in the Economic and Monetary Union (TSCG) has been challenged before the BVerfG before the ratification process has been completed. Unlike constitutions such as the French or the Czech, the German Basic Law does not provide for a specific procedure for preventive treaty review, i.e. a procedure specifically allowing the review of the constitutionality of a draft treaty before its ratification. In contrast, the BVerfG's case law relating to treaty reforms is predominantly ${ }^{26}$ based on constitutional complaints lodged by individuals who have claimed that the parliamentary approval of ratification would violate the essential content of their right to vote guaranteed by Art. 38(1) of the Basic Law (for the standard of review see Sect. 1.3.3 in more detail).

The second line of jurisprudence concerns direct or indirect challenges to the primacy of application of EU (secondary) law. In this respect the BVerfG has formulated judicial reservations in the field of fundamental rights review, ultra vires review and identity review (see in detail Sect. 1.3.4).

1.2.2 The constitutional amendment procedure is enshrined in Art. 79 of the Basic Law. According to Art. 79(1), a constitutional revision requires a law expressly amending or supplementing the text of the Basic Law. Furthermore, under Art. 79(2) any such law necessitates a two-thirds majority of the Members of the Bundestag and a two-thirds majority of the votes of the Bundesrat, i.e. the representation of the federal states. Finally, Art. 79(3) - the so-called 'eternity clause' - establishes substantial limits to constitutional amendments by protecting the key principles of the German Basic Law (constitutional identity), such as the principle of democracy, the protection of fundamental rights and the federalist structure of Germany against any constitutional revision (see Sect. 1.3.3). All explicit revisions of the German Basic Law, including those relating to EU affairs and introducing and subsequently amending Art. 23, have been put into effect according to this procedure. However, one of the particular characteristics of Germany's EU-related constitutional law that was introduced in 1992 is that Art. 23 (1) cl. 3 acknowledges that Germany's participation in the EU can have the effect of an implicit revision of the Constitution, particularly by means of transfers of sovereign powers to the EU (for more details see Sect. 1.3.1).

\footnotetext{
${ }^{25}$ BVerfG, case 2 BvR 2735/14, European Arrest Warrant II, order of 15 Dec. 2015.

${ }^{26}$ In some cases accompanied by intra-institutional proceedings.
} 


\subsubsection{The background of and reasons for the (explicit) constitutional revisions} relating to the $\mathbf{E U}$ are the following. The most important amendment in the EU context has been the constitutional revision of 1992, which introduced the EU specific integration clause (Art. 23). ${ }^{27}$ The reform primarily aimed at capturing the constitutional dimension of the European integration process, which had become apparent with the Treaty of Maastricht. A key goal was to reflect the constitutional impact of Germany's membership in the EU, but also to constitutionally frame its objectives, conditions and limits as well as the participation of the Bundestag and the federal states in EU matters. A major change effected by the constitutional reform of 1992 was that henceforth transfers of sovereignty with constitutional relevance required a double two-thirds majority both in the Bundestag and the Bundesrat. While some aspects, such as the precise conditions under which this requirement of a qualified majority applies, were disputed during the reform process and still are today (for details see Sect. 1.3.1), the constitutional reform as a whole was supported by an overwhelming political majority. Alongside the integration clause, the 1992 revision addresses several specific questions, such as the participation of EU citizens in local elections (Art. 28(1) cl. 3) and the creation of the European Central Bank (Art. $88 \mathrm{cl}$. 2). Furthermore, the mandatory creation of a parliamentary EU committee was constitutionally entrenched (Art. 45). In a comparative perspective it is interesting to see that there was a major EU-related constitutional reform going on in France at the same time, which introduced Art. 88-1 et seq. of the French Constitution. ${ }^{28}$ However, the German integration clause differs in many ways from its French counterpart and was not conceptually influenced by the latter. 29

The second reform of the German federalist system in 2006 amended Art. 23(6) in order to strengthen the participation of the federal states in EU matters in the fields of their exclusive competencies under German constitutional law. ${ }^{30}$

The constitutional revision of 2009 relating to the Treaty of Lisbon had the goal of implementing the new powers of the national parliaments under the subsidiarity protocol. As in France where a similar reform package was put in place, the German constitutional legislator designed the parliamentary right to introduce an action before the Court of Justice as a parliamentary minority right (Art. 23 (1a)). Furthermore, the Lisbon judgment of the BVerfG led to a significant change in the accompanying legislation, particularly the enactment of the so-called 'Responsibility for Integration Act', ensuring the prerogatives of the Bundestag (for more details see Sect. 1.4).

Finally, in the course of the financial crisis, several provisions relating to fiscal issues were introduced or amended in 2009. The so-called 'golden rule' in Art.

\footnotetext{
27 38th amendment of 21 Dec. 1992. For more details, see König 2000 and Schmalenbach 1996.

${ }^{28}$ See on that Ziller 2003, pp. 261 et seq.

${ }^{29}$ For more details Mayer 2004, pp. 927 et seq.

${ }^{30}$ For more details Pernice 2007, para. 118a et seq.; Classen 2007, pp. 103 et seq.; Hoffmann 2007, pp. 225 et seq.
} 
109 was introduced three years ahead of the conclusion of the Fiscal Compact. With regard to the ESM Treaty, the act approving its ratification as well as the accompanying legislation, the so-called ESM Financing Act, were enacted in 2012 and provide for a detailed and differentiated framework regarding prior parliamentary approval. $^{31}$

1.2.4 Currently there are no provisions that would be highlighted as in urgent need of amendment in view of EU membership at the political level. Furthermore there are no precise EU-related reform projects that would be underway or that would have failed, such as, for instance, the reform package presented by the Spanish State Council in 2006. What has been discussed vividly since the BVerfG's Lisbon judgment, however, are the circumstances under which a new constitution might be required for future steps of European integration (see in more detail Sect. 1.4.2).

\subsection{Conceptualising Sovereignty and the Limits to the Transfer of Powers}

1.3.1 The integration clause allowing for transfers of sovereign powers laid down in Art. 23 of the Basic Law is the key provision regarding the constitutional foundations of Germany's participation in the EU's multi-level constitutionalism. ${ }^{32}$ It can be summarised as follows. ${ }^{33}$

Article 23(1) cl. 1 stipulates a positive obligation for Germany's state institutions to 'participate in the development of the European Union' with the constitutional objective of 'establishing a united Europe' (Staatszielbestimmung). ${ }^{34}$ The clause also aims at ensuring the EU's commitment to certain key principles, namely to 'democratic, social and federal principles, to the rule of law, and to the principle of subsidiarity' and to the protection of fundamental rights at a level 'essentially comparable to that guaranteed by this Basic Law'. Hence, the integration clause goes on the 'offensive' by demanding certain structural principles which the EU should respect (Struktursicherungsklausel). However, as part of German constitutional law, the clause does not bind EU institutions, but only addresses German state organs when participating in the creation and development of the EU.

Article 23(1) cl. 2 contains the core of the integration clause, i.e. a constitutional authorisation to transfer sovereign powers, i.e. competencies, to the EU (Integrationsermächtigung). Two key functions must be distinguished: First, the clause has a constitutive function, allowing Germany to participate in an EU-wide process of constituting an autonomous public authority at the EU level by

\footnotetext{
31 See Act on Financial Participation in the European Stability Mechanism, 13 Sept. 2012, Sects. 4-6 and Act on the Treaty Establishing the ESM, 13 Sept. 2012, Art. 2.

32 Pernice 1999, pp. 706 et seq. and Pernice 2009, p. 349 with further references.

33 In detail Pernice 2006; Classen 2010; Streinz 2014.

34 Cf. Sommermann 1997, pp. 381 et seq.
} 
transferring, or better, conferring competencies on the EU (regarding the question as to how to conceptualise the act of 'transferring' sovereign powers see Sect. 1.3.2). Secondly, Art. 23(1) cl. 2 has a self-limiting function ensuring the permeability of the German constitutional order, i.e. the capacity to limit its own claim of normative exclusivity in order to enable legal rules or principles which emanate from a formally separated legal order to integrate. ${ }^{35}$

Article $23(1)$ cls. 2 and 3 provide for a dynamic integration clause, ${ }^{36}$ i.e. an integration clause that allows substantial (and implicit) changes of the Basic Law in the course of Germany's participation in the European Union without necessitating a textual amendment. According to Art. 23(1) cl. 3 the domestic approval of changes of the EU's founding treaties and comparable regulations which 'amend or supplement this Basic Law, or make such amendments or supplements possible' requires a qualified majority of two-thirds of the Members of the Bundestag and two-thirds of the votes of the Bundesrat (Art. 79(2)). Referring to the constitutional revision procedure and demanding an elevated degree of democratic legitimation, Art. 23(1) cl. 3 thus mirrors the constitutional implications that are being attributed to the transfer of sovereign powers from the perspective of German constitutional law. The consequence is that every parliamentary approval of the ratification of a reform treaty conferring new powers on the EU, like the treaties of Maastricht or Lisbon, is treated like a constitutional amendment - however, without the need to amend the text. There is an unresolved dispute between the Federal Government and the federal states as to whether every 'transfer of sovereign powers' in the sense of Art. 23(1) entails an implicit revision of the Constitution and thus requires a qualified majority (position of the federal states) or if the constitutional impact of the reform project has to be assessed on a case-by-case basis (position of the Federal Government). ${ }^{37}$ Given that a two-thirds majority has always been attained in practice, there has been, until today, no occasion for the BVerfG to decide on the matter. The same applies to the question whether the domestic approval of the ratification of international treaties supplementing EU law and not conferring competencies on the latter, such as the ESM Treaty or the Fiscal Compact, falls within the scope of application of Art. 23(1) cl. 3 and thus requires a qualified majority. ${ }^{38}$

Furthermore, any domestic statute approving the ratification of a reform instrument implicitly amending the Constitution is subject to the substantial limits established by the eternity clause in Art. 79(3). ${ }^{39}$ The reference to the 'eternity clause' in Art. 23(1) cl. 3 thus highlights the defensive dimension of the Basic Law against (hypothetical) violations of Germany's constitutional identity by the

\footnotetext{
35 For the concept see Wendel 2011a, pp. 5 et seq.

36 Ibid., pp. 145 et seq. for the different categories.

${ }^{37}$ Ibid., pp. 241 et seq. for more details and references.

38 See on that Lorz and Sauer 2012, pp. 685 et seq.

39 These limits were already highlighted before the entry into force of Art. 23 by the BVerfG, case 2 BvL 52/71, Solange I, order of 29 May 1974, BVerfGE 37, 271, 279 et seq., paras. 43 et seq.
} 
European integration process. According to the BVerfG, Germany's participation in the EU ends where the limits established by the eternity clause begin.

1.3.2 The debate on how to construe the transfer of sovereign powers is old. In Germany it dates back to the 1950s when the conceptual implications of Art. 24 were intensively discussed in the context of Germany's rearmament. Today it is widely acknowledged that both Arts. 23 and 24 of the Basic Law are an expression of the principle of open statehood (offene Staatlichkeit). ${ }^{40}$ There is also a widespread consensus amongst scholars and in the jurisprudence that the act of 'transferring' sovereign powers must not be confounded with cession (in rem) - a conception that would end up construing public authority at the EU level as a mosaic of national, cumulatively limited sovereign powers. Already back in its Solange I decision the BVerfG stated that the concept of transfer of sovereign powers must not be taken literally, and essentially means an 'opening' of the national legal order. ${ }^{41}$

Regarding the principle of sovereignty, one should note that the term 'sovereignty' is not used in the German Basic Law. With the notable exception of the judgments on the European Arrest Warrant I and the Lisbon Treaty - the latter highlighting the principle of 'sovereign statehood' (souveräne Staatlichkeit) - the concept of sovereignty does not figure in the BVerfG's EU-related case law, including the decisions of recent times. Instead, the constitutional key principle for the BVerfG's case law on treaty change is the principle of democracy, as is also and particularly true for the Lisbon judgment (see Sect. 1.3.3).

According to the BVerfG, the Basic Law 'abandons a self-serving and self-glorifying concept of sovereign statehood and returns to a view of the state authority of the individual state which regards sovereignty as "freedom that is organised by international law and committed to it". ${ }^{42}$ While almost every scholar in Germany would subscribe to the latter, there is, however, an ongoing and highly intense debate on the concrete legal consequences of Germany's open statehood and the question of how to construe the normative foundation of the applicability of EU law in Germany. This debate was particularly intense on the occasion of the Lisbon judgment, ${ }^{43}$ but also with regard to the more recent decisions in the context of the financial crisis. ${ }^{44}$ The Lisbon judgment refined the idea of conceptualising the principle of conferral through the lens of national constitutional law. According to

\footnotetext{
40 The term goes back to Vogel 1964, pp. 6 et seq.

${ }^{41}$ BVerfG, case 2 BvL 52/71, Solange I, order of 29 May 1974, BVerfGE 37, 271, 279, para. 43, within the boundaries of Germany's constitutional identity.

${ }^{42}$ BVerfG, case 2 BvE 2/08 et al., Treaty of Lisbon, judgment of 30 June 2009, BVerfGE 123, 267, 346, para. 223.

${ }^{43}$ For mainly critical assessments of the Lisbon judgment, see Schönberger 2009; Halberstam and Möllers 2009; Mayer 2011; Jestaedt 2009; Thym 2009; Tomuschat 2009; Everling 2010; Schwarze 2010. For more affirmative appraisals, cf. Schorkopf 2009; Grimm 2009; Gärditz and Hillgruber 2009.

${ }^{44}$ See the two special issues of GLJ on the ESM \& TSCG and on the OMT-reference. For a critical appraisal of the latter, cf. also Wendel 2014, pp. 263 et seq.
} 
the BVerfG, the principle of conferred powers is not only a principle of EU law, but the 'expression of the foundation of Union authority in the constitutional law of the Member States' which remain the 'Masters of the Treaties'. 45 Accordingly, the 'foundation and the limit of the applicability of European Union law in the Federal Republic of Germany is the order to apply the law' (Rechtsanwendungsbefehl) contained in the parliamentary statute approving ratification - an order 'which can only be given within the limits of the current constitutional order'. ${ }^{46}$ Despite its own claim of constitutional autonomy, EU law is thus reduced to a mere derivative of national sovereign powers, an interpretation running counter to the idea that the 'transfer of powers' is not a transferre, but a conferre instead. ${ }^{47}$ In other words, according to the BVerfG's conception, the parliamentary statutes of approval for the treaties constitute a bridge connecting national law with EU law - a bridge at the end of which stands a guardian: the $\mathrm{BVerfG}^{48}$ (see further Sect. 1.3.4).

1.3.3 Substantial limits to Germany's participation in the EU follow, according to the BVerfG, from Art. 79(3) which protects the constitutional identity of the Basic Law against constitutional revision. While in the context of European integration the term 'national constitutional limits' can simply refer to the requirement to amend the Constitution before ratification (which is the approach of the EU-related jurisprudence of the French Conseil constitutionnel), the constitutional limits derived from Art. 79(3) are red lines framing the inalienable substantive core of the German constitutional order. This means that within the normative framework of the Basic Law these limits - drafted in order to prevent a backslide into dictatorship - must not be overstepped even by the constitutional legislator. According to the BVerfG, these limits could only be (factually) overcome by superseding the Basic Law, i.e. by establishing a new constitutional order - a highly controversial claim (see Sect. 1.4.2).

Regarding the question of justiciability, the BVerfG declares individual constitutional complaints admissible (but regularly unfounded) if the complainants plausibly demonstrate that by transferring competences or authorising financial commitments, the Bundestag would lose its continuous and decisive say in fields which the BVerfG considers to be essential for shaping political development in Germany. This standard of review is intrinsically linked with the very essence of the principle of democracy as protected by the eternity clause. That the Court enables virtually every German citizen who has the right to vote to initiate a de facto objective review of constitutionality regarding domestic acts approving the ratification of EU reform measures, has raised numerous and profound critiques ever since this approach was established for the first time in the Maastricht judgment. ${ }^{49}$

\footnotetext{
45 BVerfG, case 2 BvE 2/08 et al., Treaty of Lisbon, judgment of 30 June 2009, BVerfGE 123, 267, 350, paras. 234-235.

46 Ibid., para. 343.

${ }^{47}$ For this reading, see already Kaufmann 1953.

${ }^{48}$ Kirchhof 1991.

${ }^{49}$ Tomuschat 1993; König 1994, pp. 27 et seq.
} 
However, the Court explicitly confirmed this path in its Lisbon and Greece and EFSF judgments, stating that if the Bundestag were to give up key elements of political self-determination and thus permanently deprive the citizens of their democratic influence, their claim to democracy would lapse. ${ }^{50}$ The Court held that

[t]he defensive dimension of [the right to vote] therefore takes effect in configurations in which the danger clearly exists that the competences of the present or future Bundestag will be eroded in a manner that legally or de facto makes parliamentary representation of the popular will, directed to the realisation of the political will of the citizens, impossible. ${ }^{51}$

This line of jurisprudence is thus intrinsically linked to protection of the principle of democracy and the assumption that substantive and justiciable limits to European integration can be derived from the eternity clause.

Regarding the substance of the constitutional limits to Germany's participation in the process of European integration, the BVerfG has identified five key areas within which the future conferral of competencies to the EU could bear a high risk of violating the constitutional identity of Germany and the principle of democracy in particular:

Particularly sensitive for the ability of a constitutional state to democratically shape itself are, since time immemorial [seit jeher] decisions on substantive and formal criminal law (1), on the disposition of the monopoly on the use of force by the police within the state and by the military towards the exterior (2), fundamental fiscal decisions on public revenue and public expenditure, the latter being particularly motivated, inter alia, by social policy considerations (3), decisions on the shaping of living conditions in a social state (4) and decisions of particular cultural importance, for example on family law, the school and education system and on dealing with religious communities (5). ${ }^{52}$

This catalogue was spelt out in more detail in the subsequent paragraphs of the Lisbon judgment ${ }^{53}$ - an approach vividly criticised in literature ${ }^{54}$ and openly opposed by the Czech constitutional court. ${ }^{55}$ To the great surprise of many, the BVerfG stated that Germany could not participate in a (so far only hypothetical) European federal state within the framework of the Basic Law, but would have to adopt a new constitution in this case. No other national court in the EU has spelt out an eternity clause in the context of European integration in such a detailed, albeit apodictic manner as the BVerfG has in relation to Art. 79(3). ${ }^{56}$ This approach does

\footnotetext{
${ }^{50}$ BVerfG, case 2 BvR 987/10 et al., Greece \& EFSF, judgment of 7 Sept. 2011, BVerfGE 129, 124, 169, para. 101.

${ }^{51}$ Ibid., paras. 101-102.

52 BVerfG, case 2 BvE 2/08 et al., Treaty of Lisbon, judgment of 30 June 2009, BVerfGE 123, 267,359 , para. 252 .

${ }^{53}$ Ibid., paras. 253-260.

${ }^{54}$ Cf. Schönberger 2009, pp. 1208-1209.

${ }^{55}$ Czech Constitutional Court, case Pl ÚS 29/09 Treaty of Lisbon II, judgment of 3 Nov. 2009, para. 137 et seq.

${ }^{56}$ In detail Wendel 2011a, pp. 331 et seq.
} 
not only raise fundamental objections as to its procedural dimension (de facto actio popularis), but also - and even more severely - as to its substantial foundation: It relies on an apodictic and theoretically highly questionable claim of necessary state functions, is ultimately bound to the (pre-)existence of statehood, remains widely blind to forms of genuine democratic legitimation in multilevel settings and goes along with an unprecedented deconstruction of the European Parliament. ${ }^{57}$

In its judgment on the bilateral aids for Greece and the EFSF, the BVerfG developed its jurisprudence further in the field of budgetary commitments. It held that the essence of the principle of democracy as part of the constitutional identity would be violated if the Bundestag relinquished its 'parliamentary budget responsibility' by giving up the capability to decide on the budget on its own terms. ${ }^{58}$ According to the Court,

[n]o permanent mechanisms may be created under international treaties which are tantamount to accepting liability for decisions by free will of other states, above all if they entail consequences which are hard to calculate. ${ }^{59}$

The Court also reiterated this approach in its much noted decision of 12 September 2012 by which, on the basis of a summary review, it allowed the ratification of the amendment of Art. 136 TFEU, the ESM Treaty and the Fiscal Compact at a relatively early stage and far ahead of the decision on the principal proceedings. ${ }^{60}$ In substantive terms, the decision of 12 September 2012 was characterised in particular by a remarkably strong manifestation of judicial restraint. $^{61}$

1.3.4 Unlike several other constitutions, such as those of Portugal or Croatia, the German Basic Law does not provide a clause that openly addresses the question of the primacy or direct effect of EU law. In turn, there is also no stipulation that would expressly postulate the supremacy of the Constitution vis-à-vis EU law. ${ }^{62}$ However, there is a rich and widely discussed case law on these matters. In legal and judicial practice the primacy of EU law is, on the one hand, generally accepted as a part of the acquis and as a consequence of the Basic Law's 'openness towards European law' (Europarechtsfreundlichkeit). ${ }^{63}$ On the other hand, the BVerfG has

\footnotetext{
${ }^{57}$ Halberstam and Möllers 2009, pp. 1249-1250; Schönberger 2009, pp. 1208-1209; Nettesheim 2010 , pp. 110 et seq.

${ }^{58}$ BVerfG, case 2 BvR 987/10 et al., Greece \& EFSF, judgment of 7 Sept. 2011, BVerfGE 129, 124,177 et seq., para. 120 et seq.

${ }^{59}$ Ibid., para. 128.

${ }^{60}$ BVerfG, case 2 BvR 1390/12 et al., ESM \& TSCG - summary review, judgment of 12 Sept. 2012, BVerfGE 132, 195.

${ }^{61}$ In detail Wendel 2013, pp. 41 et seq.

${ }^{62}$ Article 31 ('Federal law shall take precedence over Land law') only addresses the relationship between federal and sub-federal law within Germany.

${ }^{63}$ BVerfG, case 2 BvE 2/08 et al., Treaty of Lisbon, judgment of 30 June 2009, BVerfGE 123, 267, 347, 353 et seq. and 401, paras. 225, 240 et seq., and 340. For possible meanings of the concept, see Voßkuhle 2010; Mayer 2010, pp. 256 et seq.
} 
repeatedly challenged the position of the Court of Justice of the European Union (CJEU) regarding its claim of the unconditional primacy of EU law by formulating judicial reservations for exceptional circumstances in three fields.

The first judicial reservation relates to fundamental rights protection at EU level and has been developed in the so-called Solange jurisprudence. ${ }^{64}$ According to Solange II, the BVerfG 'will no longer exercise its jurisdiction to decide on the applicability of secondary [law] ... and it will no longer review [EU law]' by the standard of national fundamental rights as long as the EU and the Court of Justice in particular 'generally ensure effective protection of fundamental rights' at a degree 'which is to be regarded as substantially similar to the protection of fundamental rights required unconditionally by the Constitution, and in so far as they generally safeguard the essential content of fundamental rights' ${ }^{65}$ As a consequence, constitutional complaints by individuals and submissions by German ordinary and specialised courts are 'inadmissible from the outset if their grounds do not state that the evolution of European law, including the rulings of the Court of Justice ..., has resulted in a decline below the required standard of fundamental rights after the "Solange II" decision'. ${ }^{66}$ Such actions could only be declared admissible if the complainants or the referring court demonstrated 'in detail that the protection of fundamental rights required unconditionally by the Basic Law is not generally assured' at EU level. ${ }^{67}$ However, to the extent that EU law does not strictly determine national law and leaves a margin of discretion to the national legislator or administrative branch, the BVerfG will carry out a fundamental rights review. ${ }^{68}$ In this respect the BVerfG places special emphasis on the responsibility of German ordinary and specialised courts, given that it requires them under certain conditions to refer preliminary questions to the CJEU in order to decide whether or not EU law leaves a margin of discretion. ${ }^{69}$

The second judicial reservation relates to the concept of ultra vires review, i.e. the exercise of the BVerfG's self-proclaimed right to decide as a court of last instance whether an EU institution has transgressed its competences under the Treaties. ${ }^{70}$ This approach is entirely a product of judicial law-making and was foreshadowed in the Court's case law as early as $1971,{ }^{71}$ followed by increasingly

\footnotetext{
${ }^{64}$ The German word solange means 'as long as'.

${ }^{65}$ BVerfG, case 2 BvR 197/83, Solange II, order of 22 Oct. 1986, BVerfGE 73, 339, 387, para. 132; BVerfG, case 2 BvL 1/97, Banana Market, order of 7 June 2000, BVerfGE 102, 147, 164, para. 62.

${ }^{66}$ BVerfG, case 2 BvL 1/97, Banana Market, order of 7 June 2000, BVerfGE 102, 147, 164, para. 62.

${ }^{67}$ Ibid.

${ }^{68}$ See for example BVerfG, case 1 BvR 256/08 et al., Data Retention, judgment of 2 Mar. 2010, BVerfGE 125, 260, 308, paras. 185-187.

${ }^{69}$ BVerfG, case 1 BvL 3/08, Investment Allowance Act, order of 4 Oct. 2011, BVerfGE 129, 186.

${ }^{70}$ For an in-depth analysis, see Mayer 2000, pp. 87 et seq.

${ }^{71}$ BVerfG, case 2 BvR 255/69, Lütticke, order of 9 June 1971, BVerfGE 31, 145, 174, para. 97 et seq.
} 
articulate indications in $1981^{72}$ and $1987^{73}$. The first open claim of jurisdiction to review whether acts of EU law exceed the competencies attributed to the EU was made in the Maastricht judgment (1993). ${ }^{74}$ The practical modalities as well as the conceptual foundation of this judicial reservation were further substantiated in the Lisbon judgment (2009) ${ }^{75}$ the Honeywell decision $(2010)^{76}$ and the OMT reference $(2014)^{77}$. Ultra vires review essentially aims to ensure that the exercise of public authority at EU level does not exceed the so-called integration programme which has been consented to, in Germany, by an Act of Parliament. However, the substantial scope of a statute of approval can only be determined in relation to its point of reference, EU primary law. This is why ultra vires review cannot be conceptually limited to (directly or indirectly) scrutinising the compatibility of EU law with national constitutional law, but necessarily extends to examining whether EU secondary law is in conformity with EU primary law. This twofold review standard, with its roots deep in national constitutional law but with branches stretching out into EU law, presents a fundamental conceptual problem, ${ }^{78}$ given that the BVerfG is adjudicating in an area for which it has no competence either in a legal or in a technical sense.

In its Honeywell decision the Court emphasised the necessity to coordinate ultra vires review 'with the task which the Treaties confer on the Court of Justice, namely to interpret and apply the Treaties, and in doing so to safeguard the unity and coherence of Union law' ${ }^{79}$ In this light, the BVerfG specified the procedural and substantial conditions for ultra vires review. In terms of procedure the BVerfG made it unambiguously clear that the Court of Justice must be given an 'opportunity to interpret the Treaties, as well as to rule on the validity and interpretation of the legal acts in question' before the BVerfG decides on the inapplicability of an act of EU law in Germany. ${ }^{80}$ This requirement has been met by the $O M T$ reference. In terms of substance, Honeywell introduced a double test: ultra vires review can only be carried out by the BVerfG if the act of EU law in question is first 'manifestly in violation of competences' and secondly structurally significant, i.e. 'highly significant in the structure of competences between the Member States and the Union

\footnotetext{
72 BVerfG, case 2 BvR 1107/77 et al., Eurocontrol I, order of 23 June 1981, BVerfGE 58, 1, 30, para. 92.

${ }^{73}$ BVerfG, case 2 BvR 687/85, Kloppenburg, order of 8 April 1987, BVerfGE 75, 223, 235 et seq., paras. 43 et seq.

${ }^{74}$ BVerfG, case 2 BvR 2134, 2159/92, Treaty of Maastricht, judgment of 12 Oct. 1993, BVerfGE $89,155,188$, para. 106.

${ }^{75}$ BVerfG, case 2 BvE 2/08 et al., Treaty of Lisbon, judgment of 30 June 2009, BVerfGE 123, 267, 353 and 400 et seq., paras. 240 and 339 et seq.

${ }^{76}$ BVerfG, case 2 BvR 2661/06, Honeywell, order of 6 July 2010, BVerfGE 126, 286.

${ }^{77}$ BVerfG, case 2 BvR 2728/13 et al., OMT, order of 14 Jan. 2014, BVerfGE 134, 366.

${ }^{78}$ Cf. Mayer and Wendel 2014, p. 117.

${ }^{79}$ BVerfG, case 2 BvR 2661/06, Honeywell, order of 6 July 2010, BVerfGE 126, 286, 302, para. 56.

${ }^{80}$ Ibid., para. 60.
} 
with regard to the principle of conferral and to the binding nature of the statute under the rule of law'. ${ }^{81}$ In this context the BVerfG did not only express respect for the Union's own, idiosyncratic legal methodology, but also granted the CJEU a 'right to tolerance of error'. 82

Most recently the Honeywell conditions have been put to the test in the BVerfG's OMT reference. This decision is based on an ultra vires review and constitutes the first preliminary reference in the history of the BVerfG. ${ }^{83}$ Even though the BVerfG suggests that the OMT decision is in line with its Honeywell judgment, ${ }^{84}$ a closer look reveals several important deviations. The first consists in the explicit extension of ultra vires review to compliance with legal prohibitions under EU primary law - a move which is certainly not spectacular, given that a legal prohibition can always be reconstructed as a negative competence norm. The danger that this might lead to a path at the end of which stands a general EU legality review by the BVerfG could be averted if the Honeywell double test were applied strictly. In the aftermath of the $O M T$ reference it is questionable, however, if this is the case. Although the BVerfG formally holds on to the double test in general and the condition of a manifest violation of competencies in particular, the application of the latter illustrates that substantially there is not much left of it. ${ }^{85}$ Furthermore, with its $O M T$ reference the Second Senate acknowledged for the first time a so-called 'principal ultra vires objection' based on the right to vote, ${ }^{86}$ the admissibility of which depends neither on a link with a principal claim that a substantial fundamental right has been violated (as was the case in Honeywell) nor on a claim that the essence of the right to vote as protected by the eternity clause has been violated by an ultra vires act. ${ }^{87}$

The third judicial reservation relates to the concept of identity review. Although remaining rather obscure as a concept, ${ }^{88}$ the notion of national constitutional identity does not only figure in Art. 4(2) TEU, but is also used by several national supreme jurisdictions. ${ }^{89}$ In Germany the notion of constitutional identity is bound to Art. 79(3) (see above Sect. 1.3.3). On this basis the BVerfG claims to be competent to review whether an act of EU law infringes Germany's constitutional identity and is thus inapplicable in Germany. The Court has held that otherwise

\footnotetext{
${ }^{81}$ Ibid., para. 61.

${ }^{82}$ Ibid., para. 66.

${ }^{83}$ By referring preliminary questions the BVerfG essentially wants to have its own legal interpretation confirmed, according to which the OMT programme, first, is not covered by the mandate of the ECB and, secondly, violates Art. 123 TFEU.

${ }^{84}$ BVerfG, case 2 BvR 2728/13 et al., OMT, order of 14 Jan. 2014, BVerfGE 134, 366, 382 et seq., paras. 24-26.

${ }^{85}$ In more detail Wendel 2014, pp. 271 et seq.

${ }^{86}$ Schneider 2014, p. 222.

${ }^{87}$ Critically Dissenting Opinions of Judge Gerhardt, para. 6 and Judge Lübbe-Wolff, para. 17 et seq.

${ }^{88}$ See von Bogdandy 2003, p. 164.

${ }^{89}$ For a comparative overview, see Wendel 2011b, pp. 131 et seq.
} 
the fundamental political and constitutional structures of sovereign Member States, which are recognised by Article 4(2) first sentence TEU, cannot be safeguarded in any other way. In this respect, the guarantee of national constitutional identity under constitutional and under Union law go hand in hand in the European legal area. The identity review makes it possible to examine whether due to the action of European institutions, the principles ... declared inviolable in Article 79(3) of the Basic Law, have been violated. This ensures that the primacy of application of Union law only applies by virtue and in the context of the constitutional empowerment that continues in effect. ${ }^{90}$

In $O M T$, however, the BVerfG highlighted the conceptual differences between the protection of national (constitutional) identity at national and at EU level and tried to draw a clear conceptual distinction between the notion of constitutional identity under Art. 79(3) and the notion of national constitutional identity under Art. 4(2) TEU: while the protection of identity under EU law would be relative and could be subjected to, for instance, a proportionality review, the very essence of the principles protected under Art. 79(3) of the Basic Law must not be weighed against other principles (Abwägungsfestigkeit). ${ }^{91}$ In other words, the BVerfG deemed the protection of national identity provided by the Court of Justice inadequate in terms of national constitutional law.

The first time that the Court actually carried out an identity control with regard to a domestic act implementing mandatory provisions of EU law was in its European Arrest Warrant II decision regarding the extradition of an American citizen who had been convicted in absentia in Italy (for more details cf. the last paragraphs of Sects. 2.3.1, 2.3.3 and 2.3.5). ${ }^{92}$ The decision is ambiguous. On the one hand, the BVerfG claimed jurisdiction on the basis of an identity review and clearly marked the inalienable limits following from human dignity as protected by Art. 1(1) GG. On the other hand, the BVerfG interpreted both the EAW and the domestic statute in the light of $E U$ fundamental rights and came to the conclusion that there was no need to deviate from the principle of primacy, because the interpretation allegedly demanded by EU law would be in line with the substantial requirements under Art. 1(1) GG. Relying on the acte clair doctrine, the Court did not refer a preliminary question to the Court of Justice, thus refusing to enter into a dialogue with Luxemburg on the right interpretation of EU law.

\subsection{Democratic Control}

1.4.1 The participation of the German Bundestag in the process of conferring competencies to the EU as well as the decision-making process at EU level is one of

\footnotetext{
${ }^{90}$ BVerfG, case 2 BvE 2/08 et al., Treaty of Lisbon, judgment of 30 June 2009, BVerfGE 123, 267, 353, para. 240 (emphasis added).

${ }^{91}$ BVerfG, case 2 BvR 2728/13 et al., OMT, order of 14 Jan. 2014, BVerfGE 134, 366, 386, para. 29.

92 BVerfG, case 2 BvR 2735/14, European Arrest Warrant II, order of 15 Dec. 2015.
} 
the cornerstones of Germany's EU-related constitutional law. As demonstrated above (Sect. 1.3.1) Art. 23(1) of the Basic Law requires that the Bundestag approve every conferral of sovereign powers to the EU - normally by a two-thirds majority of its Members.

Furthermore, safeguarding parliamentary rights is one of the leitmotivs of the BVerfG's EU-related case law. In this jurisprudence, safeguarding parliamentary rights first and foremost means safeguarding the parliamentary representation of the popular will. According to the BVerfG, the competences of the Bundestag must not be constrained or exercised in a manner rendering (current and future) parliamentary representation at national level virtually impossible, i.e. leading to a situation in which no substantial issues would be left for the elected representatives of the people to decide on (see above Sect. 1.3.3). As a consequence, certain decision-making rights may either not be conferred on the EU or it must be ensured that the Bundestag keeps a decisive influence, if necessary by a parliamentary mandate binding the acting representatives of the German Government. In this respect, the Court coined the enigmatic, albeit catchy term of parliamentary ' $r$ sponsibility for integration'. 93

Parliamentary responsibility demands first and foremost parliamentary participation. As a consequence the BVerfG demands prior parliamentary approval for certain types of decisions at the EU level that are considered as endangering the principle of conferral by allegedly expanding the EU's competences gradually (the so-called 'dynamic treaty provisions'). ${ }^{94}$ The BVerfG takes the view that the necessary degree of democratic legitimacy of EU public authority can - at the moment - only be derived from the national sphere. The autonomous democratic mechanisms and institutions on the EU-level have, so the argument goes, a complementary character at best, but not a constitutive one. With regard to the euro crisis the BVerfG has paid specific regard to the budgetary responsibility of Parliament. Already in its Lisbon judgment the BVerfG highlighted budgetary autonomy as a key to the 'ability of a constitutional state to democratically shape itself' ${ }^{95}$ In its Greece \& EFSF judgment, the Court consequently held that the right to vote would be violated if the Bundestag relinquished its budgetary responsibility by giving up the capability to decide on the budget on its own terms by authorising

\footnotetext{
93 BVerfG, case 2 BvE 2/08 et al., Treaty of Lisbon, judgment of 30 June 2009, BVerfGE 123, 267, 351, 356 et seq. paras. 236, 245-247.

${ }^{94}$ Ibid. The BVerfG distinguishes five categories of so-called 'dynamic treaty provisions': first, the simplified treaty revision procedure under Art. 48(6) TEU and several specific provisions; secondly the 'passerelle' clauses under Art. 48(7) TEU and several specific stipulations; thirdly, the flexibility clause under Art. 352 TFEU; fourthly, the so-called 'emergency brakes' under Arts. 48(2), 82(3) and 83(3) TFEU; fifthly and finally specific stipulations according to which the Council - after obtaining the consent of the European Parliament - can adopt unanimously decisions in 'sensitive' fields such as criminal law (Art. 83(3) sub-para. 3 TFEU). It is important to note that only the first and the second category concern the simplified (and insofar 'dynamic') amendment of EU treaty law. The other categories relate essentially to the legislative process at EU level.

${ }^{95}$ BVerfG, case 2 BvE 2/08 et al., Treaty of Lisbon, judgment of 30 June 2009, BVerfGE 123, 267, 359 et seq., paras. 252, 256.
} 
financial commitments. ${ }^{96}$ Regarding the decision-making processes within the ESM, the Court considered the relevant provisions on the involvement of the Bundestag - specified in the Act of assent to the ESM Treaty as well as in the so-called ESM Financing Act - to comply with this requirement to a large extent. ${ }^{97}$ Read together, both statutes provide for a detailed and differentiated framework regarding prior parliamentary approval. Above all, they ensure that the key activities of the German ESM representatives are determined and controlled by the Bundestag and thus provided with sufficient democratic legitimation. ${ }^{98}$ In order to prevent any possibility of circumventing parliamentary participation, the Court has deemed it necessary to demand an interpretative safeguard under public international law, aiming at the exclusion of any interpretation of the ESM Treaty allowing payment obligations that exceed the defined maximum sum without the consent of the Bundestag. ${ }^{99}$

Furthermore, parliamentary responsibility calls for parliamentary information: no control without prior information. According to the BVerfG, the (national) constitutional principle of democracy requires access to information in a way that allows the Bundestag to assess the essential foundations and consequences of its decisions and thus exercise its parliamentary responsibility. ${ }^{100}$ Like several national constitutions, the German Basic Law contains a provision on the parliamentary right to information in EU affairs: according to Art. 23(2) cl. 2 - a norm concretised by an ordinary Act of Parliament - the Bundestag has a right to be comprehensively informed by the Government at the earliest possible time on 'matters concerning the European Union'. In a decision of 19 June 2012, the BVerfG decided that the Federal Government had infringed this right to information with regard to certain key documents relating to the negotiations on the ESM and on the so-called Euro Plus Pact. ${ }^{101}$ The Court interpreted the term 'matters concerning the European Union' in a broad manner, thus extending the scope of application of Art. 23(2) to 'international treaties that complement European Union law or otherwise show particular proximity' to it ${ }^{102}$ and thus qualified the establishment of the ESM as a matter falling within the scope of application of Art. 23(2). ${ }^{103}$ The Court also established an obligation for the German Government to provide information in a particularly comprehensive and detailed way, given that the ESM concerns the

\footnotetext{
${ }^{96}$ BVerfG, case 2 BvR 987/10 et al., Greece \& EFSF, judgment of 7 Sept. 2011, BVerfGE 129, 124, 177, para. 121.

${ }^{97}$ BVerfG, case 2 BvR 1390/12 et al., ESM \& TSCG - summary review, judgment of 12 Sept. 2012, BVerfGE 132, 195, 269 et seq., paras. 280-299 [EN translation, version 2014].

${ }^{98}$ Ibid., para. 287.

99 Ibid., para. 253.

${ }^{100}$ Ibid., para. 215.

${ }^{101}$ BVerfG, case 2 BvE 4/11, ESM \& Euro Plus Pact, judgment of 19 June 2012, BVerfGE 131, 152.

102 Ibid., para. 100.

${ }^{103}$ Ibid., para. 135.
} 
overall budgetary responsibility of the Bundestag. ${ }^{104}$ In 2012 the BVerfG, for the very first time, put the essence of the parliamentary right to information explicitly under the protection of Art. 79(3). The 'core of the right of Parliament to be informed' is, according to the Court, 'entrenched' in the eternity clause. ${ }^{105}$ It is on this basis that the Court demanded, in its ESM \& TSCG case, for the second interpretative safeguard under public international law, ensuring that the provisions in the ESM Treaty on the inviolability of documents and on professional secrecy do not restrain the comprehensive information of the Bundestag. ${ }^{106}$

Another implication relates to the aspect of intra-parliamentary allocation of tasks, i.e. the question of the extent to which responsibilities may be exercised by parliamentary special committees and to what extent their exercise must be reserved to the plenary session. In a judgment of 28 February 2012, the Court established the basic rule that the Bundestag's right to decide on the budget and its overall budgetary responsibility generally have to be 'exercised through deliberation and decision-making in the plenary sitting'. ${ }^{107}$ Arguing that the constitutional rights of Members of Parliament are violated if they are excluded from substantial decisions affecting the German Bundestag's budgetary responsibility, the BVerfG essentially scrapped a statute according to which the Bundestag's competences to decide on certain measures within the framework of the European Financial Stability Facility (EFSF) were, in cases of particular urgency and confidentiality, to be exercised by a special parliamentary committee (Sondergremium) composed of nine members. ${ }^{108}$ The Court accepted the conferral of responsibilities to the special committee only in strictly limited cases. ${ }^{109}$

1.4.2 The voting mode of referendum (popular vote) is not foreseen by the Basic Law - neither in domestic nor in EU affairs. However, if a new constitution were to be adopted by the German people, this would most likely presume a referendum. In its Lisbon judgment the BVerfG suggested that the limits to further European integration following from Art. 79(3) could be overcome by the adoption of a new constitution in the sense of Art. 146 - a stipulation which was amended in 1990 with the aim of paving the way for a new constitution after reunification, but which has never been applied in this context, because of the will of the overwhelming political majority to keep the Basic Law in force. ${ }^{110}$

\footnotetext{
104 Ibid., para. 145.

105 BVerfG, case 2 BvR 1390/12 et al., ESM \& TSCG - summary review, judgment of 12 Sept. 2012, BVerfGE 132, 195, 241 et seq., para. 215 [EN translation, version 2014].

106 Ibid., para. 259.

107 BVerfG, case 2 BvE 8/11, Special Parliamentary Committee, judgment of 28 Jan. 2012, BVerfGE 130, 318, 347, para. 113 (emphasis added).

108 Ibid., paras. 133-153.

109 Ibid., para. 150.

${ }^{110}$ Until 1990 the Basic Law contained a provision (the former Art. 23) allowing the accession of East Germany to the Federal Republic of Germany and the applicability of the German Basic Law
} 
According to the BVerfG, Art. 146 would have to apply particularly if Germany wanted to participate in a future European federal state. For the BVerfG this aspect is even justiciable: a complainant could rely on the right to vote (Art. 38(1)) in order to challenge an alleged loss of 'sovereign statehood' because the only power with the right to repeal the Basic Law and with it the German federal state, would be the constituent power of the people. In its Lisbon judgment, the BVerfG held that the 'pre-constitutional right' to give oneself a constitution was declaratively mirrored in Art. 146. ${ }^{111}$ While Art. 146 thus reflects an outer-systemic right of participation to create a new system, Art. 38(1) ensures an inner-systemic right of participation within the existing system. The logical fracture is that according to the BVerfG, the electorate shall be entitled, by relying on its inner-systemic right to vote, to become the guardian of the outer-systemic constituent power reflected in Art. 146. ${ }^{112}$ While courts like the French Conseil constitutionnel or the Czech Constitutional Court stay within the existing constitutional order by referring to the constitutional revisionary power, i.e. the constitutional legislator, if constitutional limits have been reached, the BVerfG virtually transcends the constitutional order by which it is itself constituted when it refers to a pre-constitutional (revolutionary?) 'right' to give oneself a constitution. ${ }^{113}$ The Court thus leaves the Germans with quite an astonishing choice. They may either remain part of the so-called association of sovereign and 'fully democratically' (volldemokratisch) organised states the peoples of which remain the sole subjects of democratic legitimation, or they may participate in the creation of a European federal state, which would require the supersession of one of Germany's most vaunted post-war-inventions, the Basic Law.

\subsection{The Reasons for, and the Role of, EU Amendments}

1.5.1 As to the background, reasons and comparative context of the (explicit) constitutional revisions relating to the EU, see above at Sect. 1.2.3. Compared to other countries the input of comparative law in the process of drafting the integration clause was rather weak. This is also due to the fact that Germany was one of the first countries to enact EU-related constitutional provisions. An exception to the wide absence of comparative influence regarding the drafting of integration clauses are the stipulations regulating the parliamentary subsidiarity control. To construe the latter as a parliamentary minority right, is an idea developed simultaneously and with cross-border influence - in France and Germany.

in East Germany after accession. This was the clause on which the reunification was based under domestic constitutional law.

${ }^{111}$ BVerfG, case 2 BvE 2/08 et al., Treaty of Lisbon, judgment of 30 June 2009, BVerfGE 123, 267, 331 et seq. and 348, paras. 179-180 and 228.

112 Cf. Halberstam and Möllers 2009, p. 1256.

113 See the critique of Jestaedt 2009, pp. 511-513. 


\subsubsection{Not applicable.}

1.5.3 In the author's view the EU-related, national constitutional case law plays an eminent role within the framework of Europe's multilevel-constitutionalism. ${ }^{114}$ It not only regulates key questions such as the procedures for conferrals of competencies, the participation of the people, national parliaments or federal entities in the process of European integration, but also opens up the national legal sphere. It makes national constitutional law permeable and responsive. Given the specifics of EU law as an autonomous legal order claiming direct effect and primacy in application in the Member States, building on their institutional and administrative systems, creating a European citizenship with genuine individual rights and thus complementing the national constitutional sphere in many ways, one should recommend, from a comparative perspective, the insertion of EU-specific constitutional provisions addressing these issues.

Given the substantial impact of the European legal order on national constitutional law, the 'EU capability' is of highest importance for the constitutional order of a modern EU Member State. Comparative law can help to identify the need or appropriateness of reform in this field. In this light, a modern integration clause should particularly abandon misleading concepts such as the 'transfer' of sovereign powers which conceptually reduces the autonomous public authority at EU level to a mere derivative of national sovereign powers (which is why the term 'confer' or 'entrust' seem to be more appropriate, see Sect. 1.3.2). Furthermore, a modern integration clause should highlight the complementary and mutually stabilising dimension of the different constitutional levels. ${ }^{115} \mathrm{~A}$ reformed Integrationsermächtigung could, for example, begin as follows: Germany can, conjointly with other European states, confer tasks and competencies to the European Union, by founding and developing a common basic order that henceforth constitutes, together with this Basic Law and with respect for its core principles, the legal basis for the exercise of public authority in Germany.

\section{Constitutional Rights, the Rule of Law and EU Law}

\subsection{The Position of Constitutional Rights and the Rule of Law in the Constitution}

2.1.1 After the total neglect of human rights during the rule of the National Socialist Party in Germany, the protection of fundamental rights became a primary concern for the authors of the Basic Law. The Bill of Rights was moved from the end of the constitution, the place that it occupied in the Weimar Constitution, to the beginning.

\footnotetext{
114 Pernice 1999, pp. 706 et seq.; Pernice 2009, pp. 349 et seq. with further references.

115 For suggestions how to advance the EU related national constitutional law, see Wendel 2011a, pp. 206 et seq., 270 et seq. and 409 et seq.
} 
If this was merely of symbolic value, the decision to place a guarantee of human dignity at the top of the Bill of Rights had considerable legal relevance.

Dignity is understood as the foundation for the fundamental rights that follow. It is framed in particularly strong language. Dignity is declared to be 'unantastbar', a term used only with regard to dignity and meaning 'untouchable' or 'sacrosanct' 116 This qualification endows dignity with an absolute character, as has been stated in the jurisprudence of the Constitutional Court from the very beginning. ${ }^{117}$ Differently from the rights that follow, it may not be limited and is not subject to balancing. No infringement of dignity is justifiable. If a conflict between dignity and other human rights arises, dignity always trumps. Moreover, according to the text of Art. 1, the state is obliged not only to respect but also to protect dignity. To respect dignity means that the state itself has to avoid all actions that would violate Art. 1; protecting dignity means that the state has to prevent others from endangering dignity.

Article 1 is followed by a catalogue of 18 fundamental rights, most of which are classical liberties. Unlike in the Weimar Constitution, almost no social or economic rights are adopted in the Basic Law. A few more rights considered as equivalent in rank and protection to the guarantees in the Bill of Rights are dispersed over other parts of the Basic Law (e.g. the right to vote, Art. 38, the right to be heard in court, Art. 103, several guarantees in connection with imprisonment, detention etc., Art. 104).

The authors of the Basic Law also made an effort to strengthen the legal force of fundamental rights. In previous German constitutions their impact had been rather minor. Still, during the Weimar Republic, fundamental rights were considered as not binding on the legislature. Social and economic rights were not regarded as legal norms at all, but rather as political programmes. In the Basic Law, all human rights are declared directly applicable and binding on all state powers including the legislature (Art. 1(3)). Limitations of fundamental rights require a law. However, such a law may not touch upon the very essence of a right (Art. 19(2)). All courts are constitutionally obliged to respect and enforce fundamental rights. Article 19(4) guarantees access to the courts to everyone who feels that his rights (not only fundamental rights) have been violated by a public authority. Nevertheless, the incompatibility of a parliamentary law with the Bill of Rights may only be ascertained by the Constitutional Court. If lower courts are of the opinion that a law which they have to apply in a case is incompatible with the Basic Law, they have to stay the procedure and refer this question to the Constitutional Court (Art. 100).

In addition to the norm control procedures (Arts. 93 and 100), the Basic Law provides for an individual complaint that any person can raise if the person alleges

\footnotetext{
116 The usual translation of 'unantastbar', i.e. 'inviolable', does not reflect the enhanced protection that dignity enjoys, because the term 'inviolable' ('unverletzlich') appears frequently in connection with fundamental rights.

${ }^{117}$ Most recently confirmed in BVerfG, case 2 BvR 2500/09, inadmissibility of evidence obtained from illegal surveillance of private property (Verwertungsverbot Wohnraumüberwachung), order of 7 Dec. 2011, BVerfGE 130, 1, 22.
} 
that a public authority, including the judiciary, has violated one or more of his fundamental rights (Art. 93 (1) No. 4 a). Out of the nearly 7,000 cases that arrive at the Constitutional Court per year, more than $95 \%$ are individual complaints. A number of important decisions that have developed and enforced fundamental rights have been rendered upon individual complaints. The review procedures are further highlighted in Sect. 2.8.3.

The contribution of the jurisprudence of the Federal Constitutional Court to the relevance of fundamental rights for political behaviour and the everyday life of citizens can hardly be overestimated. ${ }^{118}$ Foreign observers declare it to be exceptional and exemplary for many other jurisdictions. ${ }^{119}$ Polls show that the BVerfG routinely has the highest confidence rate of all public institutions.

Alongside the Bill of Rights that covers the first nineteen articles of the Basic Law, a number of general principles of law are formulated in Art. 20 and also in Art. 28, which requires homogeneity between the Basic Law and the various constitutions of the German Länder. These principles are: republicanism, democracy, the rule of law, social state and federalism. According to Art. 79(3), they are unamendable. Most of them, with the exception of republicanism and the social state principle, are concretised in the subsequent sections of the Constitution. A number of additional guarantees have been derived from these principles by the jurisprudence of the BVerfG. This is particularly true for the rule of law principle, which has become the roof under which a number of specific legal protections have been developed, such as the non-retroactivity of laws (which is explicitly guaranteed only with regard to criminal law statutes, Art. 130(2)) and the protection of legitimate expectations.

2.1.2 Most fundamental rights are accompanied by a limitation clause. Some of these clauses are unspecified ('by law or pursuant to law'), some contain further qualifications, such as rules as to the purpose, conditions and means of limitation. Some do not have a special limitation clause at all, which, according to the BVerfG, does not mean that they are exempt from limitations, but that only limitations having a basis in other norms of the Constitution, especially in other fundamental rights, are permitted. ${ }^{120}$ This is a consequence of the methodological premise of the BVerfG that the Constitution has to be interpreted as a unity. In addition to the limitation clauses added to certain fundamental rights, there is a general provision requiring that laws which limit a fundamental right have to be general (Art. 19(1)) and that the very essence of the right is protected against any limitation (Art. 19(2)).

The jurisprudence of the BVerfG has added some further guarantees to these rules, the most important being the principle of proportionality which originated in the jurisprudence of the BVerfG and has meanwhile been adopted by many jurisdictions all over the world. ${ }^{121}$ According to this principle, a law that limits a

\footnotetext{
${ }^{118}$ For a summary, see Grimm 2015b, pp. 9-29.

119 See Robertson 2010, pp. 40 et seq.

${ }^{120}$ BVerfG, case 1 BvR 435/68, Mephisto, order of 24 Feb. 1971, BVerfGE 30, 173, 193.

121 See map in Barak 2012, p. 182.
} 
fundamental right has to have a legitimate purpose (1), it must be suitable (2) and necessary (3) to achieve its purpose and strike a proper balance between the competing legal goods (4), i.e. the fundamental right that has been limited by the law under scrutiny on the one hand and the legal good that the law wants to protect (often itself a fundamental right) on the other hand. The proportionality principle also applies to legal acts, be they court decisions, administrative acts or other legally relevant behaviour of state agents. Over time, the burden of fundamental rights protection has come to rest almost entirely on the safeguards provided by the principle of proportionality. Violations of the specific limitation clauses are rare, and the guarantee of the essence of a right in Art. 19(2) is seldom relevant because the proportionality principle intervenes at an earlier stage.

2.1.3 The rule of law (Rechtsstaat) is explicitly guaranteed in Art. 28. Important elements of the principle are enumerated in Art. 20, yet without mentioning the term 'Rechtsstaat'. The basic element of the rule of law is that the state has to rule not only by law but also according to the law. This means that the state is not only the creator of the law that binds the citizens, but it also submits itself, including its highest organs, to the law (the so-called 'Vorrang des Gesetzes'). This in turn enables the citizens to foresee state actions and to plan their behaviour accordingly. As a consequence, legal certainty (Rechtssicherheit) is regarded as a value in itself, which means that the rule of law may enter into conflict with the demands of justice (e.g. if a perpetrator cannot be punished because evidence was obtained unlawfully). Legal certainty as an element of the rule of law requires that laws are formulated in a way that the addressee can recognise what behaviour is required or forbidden. This of course implies that laws are not only promulgated but also published. An unpublished legal rule does not take legal force.

By the same vein, retroactive laws are prohibited under the rule of law. This is explicitly guaranteed in the Basic Law with regard to criminal law (Art. 103(2)). It has been extended by way of interpretation to other laws as well, as a consequence of the rule of law. However, a distinction is made between so-called genuine and non-genuine retroactivity (echte und unechte Rückwirkung). Genuine retroactivity means that a law is applied to a situation or behaviour that existed or had happened before the law was enacted. Non-genuine retroactivity means a change in an existing legal situation for the future. Different criteria apply to the two forms of retroactivity. Genuine retroactivity requires a particularly strong justification. For non-genuine retroactivity good reasons are sufficient. The principle of proportionality has to be observed. The borderline between the two forms is not particularly clear, and the attempts of the BVerfG to define the two categories have varied over time.

In cases of lawful retroactivity, the rule of law principle requires that the legitimate expectations of the addressees of the law are honoured (Vertrauensschutz). If the citizens could have legitimately trusted in the continuation of a law or situation created by law, the legislature may be obliged to compensate for loss that addressees of the law suffer due to changes in the law or, more often, to provide temporary arrangements that would allow the addressees to adjust 
to the new situation. In such cases, the statute that disproportionately burdens citizens is not annulled, rather the legislature is obliged to amend it in due time.

However, the rule of law would be incomplete if it only required that the state rule according to law. The state would then be free to decide where it is bound by law and where it can act according to will. The 'Vorrang des Gesetzes' is therefore accompanied by the 'Vorbehalt des Gesetzes', which defines the areas where state action requires a basis in law (the term 'law' covers laws enacted by Parliament and decrees (Verordnungen) enacted by the Government upon an explicit delegation by Parliament). A law is explicitly required for limitations of fundamental rights (Art. 19). However, the BVerfG has extended this requirement beyond the limits of fundamental rights infringements. In areas covered by fundamental rights, all important decisions have to be taken by Parliament itself and cannot be left to the Government in the form of a decree (the so-called 'Parlamentsvorbehalt'). The 'Parlamentsvorbehalt' thus further restricts the constitutional requirements for a delegation of legislative powers in Art. 80 GG.

Finally, the rule of law means that independent courts have the power to control whether the state complies with the laws that bind its activity. This is guaranteed in Art. 19(4), as is the independence of the courts in Art. 97.

The rule of law principle, which was originally objective law (mandatory for the state, but not necessarily entitling individuals), has been transformed into subjective rights of the individual, such that elements which have not explicitly been guaranteed in the form of a subjective right (such as the right to be heard in court, Art. 103) can be invoked before the courts. They also play an important role in the individual complaints to the BVerfG. Individual complaints can only be based on alleged violations of fundamental rights. Yet once this hurdle has been overcome, the BVerfG also takes violations of objective principles into account. This is because infringements of fundamental rights are only justified if they are based on a law which is itself constitutional. This opens the door for criteria that are themselves not subjective rights. As a consequence, the rule of law plays an important role in the jurisprudence of the BVerfG, not only in cases brought by organs of the state or the Länder, but also in individual complaints. ${ }^{122}$

\subsection{The Balancing of Fundamental Rights and Economic Freedoms in EU Law}

2.2.1 The answer to this question requires some remarks on balancing fundamental rights, especially personal and economic rights, on the national level.

The BVerfG has often declared that no hierarchy exists among the fundamental rights of the Basic Law. The only exception is dignity, which is subject to neither

\footnotetext{
${ }^{122}$ For an English summary of the rule of law and relevant case law of the German Constitutional Court, see Currie 1994, pp. 162 et seq. and pp. 116-134.
} 
limitation nor to balancing. However, one can find language in the jurisprudence that relativises this assumption. In the first abortion decision, the Court admitted that different ranks in the order of values (Wertordnung) of the Basic Law exist. The Court continued: 'Human life represents a supreme value (Höchstwert) within the constitutional order; it is the vital basis of human dignity and the precondition of all other fundamental rights'. ${ }^{123}$ Other decisions suggest a ranking in certain constellations, particularly in conflicts between freedom of speech (Art. 5) and personal honour and privacy (Art. 2 sect. I). In the Lüth case the BVerfG stated that freedom of speech is 'one of the most distinguished (vornehm) human rights of all. For a free democratic political order it is absolutely foundational ... In a certain sense it is the basis of every freedom there is'. ${ }^{124}$

In general, the BVerfG grants stronger protection to personal and communicative rights than to economic rights. This matters in the process of balancing. In step 3, the Court examines whether there are other means that would equally fulfil the purpose of the law but affect fundamental rights less severely. The Court grants the legislature wide discretion with regard to the choice of means in the case of economic regulation. The more personal rights are limited, the more discretion shrinks. Since it is often uncertain what effect a law will have and thus only prognostic considerations are available, the legislature is under a constitutional duty to undertake a serious investigation. However, the Court will not replace the legislature's prediction with its own. It may be, however, that a risk appears so great that the legislature is constitutionally barred from taking it. This is especially true for experimental laws if it would be extremely difficult or almost impossible to revise the experiment, should it produce considerable negative effects for fundamental rights. ${ }^{125}$

While the second and third steps of the proportionality test concern a means-ends relationship between the purpose of the law and the ways to achieve it in which the fundamental right that is limited plays no role, the limited right is re-introduced in step 4. ${ }^{126}$ Here a cost-benefit analysis is conducted between the cost to the fundamental right by the statutory limitation and the benefit for the legal good in the interest of which the fundamental right is limited. Since in most cases the legal good is itself a fundamental right, the weight that the Court gives to the competing rights matters.

However, the balancing is not undertaken in the abstract. The question is not which right is more and which is less important. The question is rather one of the

\footnotetext{
${ }^{123}$ BVerfG, case 1 BvF 1/74 et al., Abortion I, judgment of 25 Feb. 1975, BVerfGE 39, 1, 42.

${ }^{124}$ BVerfG, case 1 BvR 400/51, Lüth, judgment of 15 Jan. 1958, BVerfGE 7, 198, 208.

${ }^{125}$ See, e.g., BVerfG, case 1 BvL 89/87, Broadcasting, judgment of 16 June 1981, BVerfGE 57, 295,322 et seq.

126 This difference is often overlooked. See Grimm 2007.
} 
importance of the aspect of the fundamental right that is affected by the limitation and the intensity of the intrusion on the one hand, versus the importance of the aspect of the competing right that profits from the limitation and the importance of the profit on the other hand. This is a case-by-case assessment for which it is helpful that the Court distinguishes between what can be called the core and the periphery of the right. When it comes to restrictions of personality rights, a threefold differentiation can often be observed, namely between a social, a private and an intimate sphere. Similarly, an internal differentiation of economic rights is made. For example, regarding freedom of property (Art. 14), the Court distinguishes between a personal and a mere functional aspect of property. Whenever property serves as a material basis for the free development of personality, it receives the strong protection that personal rights enjoy. Where property in its function as a basis or an object of economic transactions is concerned, its weight is lower. ${ }^{127}$ The same is true for freedom of profession (Art. 12). The individual choice of a profession is more strongly protected than the exercise of a profession. ${ }^{128}$ In the field of regulation of the economy, in the interest of social justice, workers' protection, consumer protection, protection of the environment and the like, the laws that limit economic rights are usually upheld.

It is widely accepted that in the EU, the four economic freedoms prevailed over personal rights for a long time. The CJEU's mission to establish the Common Market gave these rights their particular strength. Even if social benefits were extended beyond the scope defined by the national laws, this was done not in the personal interest of the beneficiaries, but in the interest of free movement. The question is whether this will change after the adoption of the European Charter of Fundamental Rights (Charter). The decision of the CJEU most frequently quoted in this respect is Omega, ${ }^{129}$ in which the Court agreed that the national guarantee of human dignity in the German Basic Law could justify an exception from the free movement of goods. Yet the CJEU reached this result after balancing human dignity against the free movement of goods, which means that in principle, another outcome could also have been possible, whereas in German constitutional law dignity is guaranteed absolutely so that in a conflict between dignity and any other fundamental right, dignity always trumps. The balancing is further discussed in Sect. 2.8.2.

A special problem is the relation between the European Charter and the national bills of rights. When do national fundamental rights apply and when do European fundamental rights? This will be discussed in Sect. 2.11.1.

${ }^{127}$ See, e.g., BVerfG, case 1 BvR 532/77 et al., Co-determination, judgment of 1 Mar. 1979, BVerfGE 50, 290, 340.

${ }^{128}$ See, e.g., BVerfG, case 1 BvR 596/56, Pharmacy, judgment of 11 June 1958, BVerfGE 7, 377. BVerfGE 7, 377 (1958).

${ }^{129}$ Case C-36/02 Omega [2004] ECR I-09609. 


\subsection{Constitutional Rights, the European Arrest Warrant and EU Criminal Law}

\section{Implementation of the European Arrest Warrant (EAW) in Germany: the IRG}

The EAW Framework Decision ${ }^{130}$ was implemented into German law as a part of the Act on International Cooperation in Criminal Matters (Gesetz über die Internationale Rechtshilfe in Strafsachen, hereinafter IRG). The respective provisions can be found in Part VIII regarding the 'Extradition and Transit to Member States of the European Union' in Sects. 78-83i IRG. This particular part was introduced into the Act in 2006 after the European Arrest Warrant I decision of the BVerfG of 2005, ${ }^{131}$ which struck down the former version enacted in 2004. In 2013 Germany issued a total of 1,932 EAWs, and a total of 12,091 alerts were introduced by other Member States based on the EAW. ${ }^{132}$

The most relevant provisions regarding the EAW in the IRG for this report are:

\section{Section 78 IRG [Precedence of Part VIII] ${ }^{133}$}

(1) Unless this Part contains specific regulations, the other provisions of this Act shall apply to the extradition and transit to Member States of the European Union.

(2) This Part shall take precedence before the international agreements mentioned in s. 1(3) insofar as it contains exhaustive regulations.

\section{Section 79 IRG [Duty to Grant Assistance; Preliminary Decision]}

(1) Admissible requests for extradition or transit by a Member State may only be denied as far as provided in this Part. The decision refusing assistance must contain reasons.

(2) Prior to the decision of the Oberlandesgericht on admissibility the authority in charge of granting assistance shall decide whether it intends to raise objections under s. $83 \mathrm{~b}$. The decision not to raise objections must contain reasons. It is subject to review by the Oberlandesgericht in the procedure under s. 29; the parties shall be heard. When being notified under s. 41(4) the person sought shall be warned that in the case of simplified extradition a judicial review under the 3rd sentence above is not available.

(3) If facts arising after a decision under subsection (2) 1st sentence above which are capable of giving rise to obstacles to admissibility do not lead to a refusal, the decision not to raise objections shall be subject to review in the procedure under s. 33 .

\section{Section 80 IRG [Extradition of German Citizens]}

(1) The extradition of a German citizen for the purpose of prosecution shall not be admissible unless

\footnotetext{
${ }^{130}$ Council Framework Decision of 13 June 2002 on the European arrest warrant and the surrender procedures between Member States (2002/584/JHA), [2002] OJ L 190/1.

${ }^{131}$ BVerfG, case 2 BvR 2236/04, European Arrest Warrant I, judgment of 18 July 2005, BVerfGE 113, 273.

${ }^{132}$ Council of the European Union, 8414/414 REV 4, LIMITE.

133 Translation of the IRG by Michael Bohlander and Wolfgang Schomburg. Translation of Sect. 83 (1) No. 3, (2), (3) and (4) by Tobias Reinbacher.
} 
1. measures are in place to ensure that the requesting Member State after a final conviction to a sentence of imprisonment or other sanction will offer to return the person sought, if he so wishes, to Germany for the purpose of enforcement and

2. the offence has a substantial link to the requesting Member State.

A substantial link to the requesting Member State typically exists if the conduct underlying the offence occurred wholly or in its essential parts on its territory and the result occurred there at least to an essential degree, or if it relates to a serious offence with a typically transborder quality which was committed at least in part on its territory.

(2) If the conditions of subsection (1) 1st sentence No. 2 above are not fulfilled, the extradition of a German citizen for the purpose of prosecution shall be inadmissible unless

1. the conditions of subsection (1) 1st sentence No. 1 above are fulfilled and the offence

2. has no substantial link to German territory and

3. would under German law also be an unlawful act fulfilling the actus reus and mens rea elements of an offence under German law or would mutatis mutandis be such an offence under German law, and if upon an individual balancing of the competing interests the interest of the person sought in his non-extradition does not outweigh the other interests.

A substantial link to the domestic territory typically exists if the conduct underlying the offence occurred wholly or in its essential parts on German territory and the result occurred there at least to an essential degree. When balancing the interests, special regard shall be had to the nature of the offence, the practical requirements and possibilities of an effective prosecution, the interests of the person sought as protected under civil liberties, taking into account the goals related to the creation of a European Judicial Space and weighing them against each other. If because of the offence on which the extradition request is based a decision by the prosecution service or by a court exists ordering the discontinuance or nonlieu of a criminal investigation, this decision and the reasons for it must be taken into account. This shall also apply if a court has listed a case for trial or has issued a summary judgment in written proceedings.

(3) The extradition of a German citizen for the purpose of enforcement shall be inadmissible unless the person sought after being notified of his rights gives his consent and this is noted in a judicial record. S. 41(3) and (4) shall apply mutatis mutandis.

(4) If the request for enforcement of a final sentence of imprisonment or other custodial sanction was preceded by an extradition because of the offence on which the sentence is based under subsections (1) or (2) above or if the request is based on the non-consent of the person sought under subsection (3) above, s. 49(1) No. 3 shall not apply. If in the case of such a request and for the purposes of conversion under s. 54 there is no maximum penalty for the offence under German law because s. 49(1) No. 3 does not apply, the maximum penalty shall be two years' imprisonment.

\section{Section 81 IRG [Extradition for the Purpose of Prosecution and Enforcement]}

\section{S. 3 shall apply under the proviso that}

1. extradition for the purpose of prosecution shall not be admissible unless under the law of the requesting Member State the offence is punishable by imprisonment or another sanction with a maximum term of no less than twelve months,

2. extradition for the purpose of enforcement shall not be admissible unless under the law of the requesting Member State a custodial sanction of no less than four months is to be enforced, 
3. extradition in tax, customs and currency matters shall also be admissible if the German law does not recognise similar taxes or does not contain similar tax, customs or currency laws as the law of the requesting Member State,

4. double criminality shall not need to be established if the offence on which the request is based is under the law of the requesting State punishable by a custodial sanction with a maximum term of no less than three years and is listed in one of the categories of offences listed in article 2 (2) of the Council Framework Decision 2002/584/JHA ... .

\section{Section 82 IRG [Non-Applicability of Provisions]}

Ss. 5, 6 (1), 7 and, insofar as a European arrest warrant is concerned, s. 11 shall not apply.

\section{Section 83 IRG [Additional Conditions of Admissibility]}

Extradition shall not be admissible

(1) 1. if the person sought has already been finally tried in another Member State for the offence on which the request is based and that in the case of a conviction the sentence has been enforced, is currently being enforced or can no longer be enforced under the law of the convicting State,

2. if the person sought was at the time of the offence not criminally liable under s. 19 of the Strafgesetzbuch or

3 . if in the case of a request for the purpose of enforcement of a sentence the convicted did not appear in person at the trial which resulted in the decision or

4. if the offence upon which the request is based is under the law of the requesting Member State punishable by life imprisonment or another custodial sanction for life or if the person sought was sentenced to such a penalty and there is no review of the penalty or sanction either upon request or propio motu after a period of no longer than 20 years.

(2) Subsection 1 No. 3 notwithstanding extradition shall be admissable if

1. the convicted person

a) in due time

aa) either was summoned to the trial which resulted in the decision in person or

bb) by other means actually received official information of the scheduled date and place of the trial in such a manner that it was unequivocally established that he or she was aware of the scheduled trial and

b) was informed that a decision may be handed down in absentia,

2. the convicted person, in a case where defence counsel had been appointed, frustrated the service of a summons through flight in the knowledge of the proceedings, or

3. the convicted person being aware of the scheduled trial, had given a mandate to a legal counsellor to defend him or her at the trial, and was indeed defended by that counsellor at the trial.

(3) Subsection 1 No. 3 notwithstanding extradition shall be admissable if the convicted person

1. expressly stated that he or she does not contest the decision or

2. did not request a retrial or an appeal within the applicable time frame.

The convicted person must be expressly informed about the right to a retrial, or an appeal, in which the person has the right to participate and which allows the merits of the case, including fresh evidence, to be re-examined, and which may lead to the original decision being reversed. 
(4) Subsection 1 No. 3 notwithstanding extradition shall also be admissable if the convicted person will be personally served with the decision without delay after the surrender and will be informed of his or her right to a retrial or an appeal mentioned in Subsect. 3 sentence 2 and the of the applicable time frame.

\section{Section 83a IRG [Extradition Documents]}

\section{Section 83b IRG [Obstacles to Granting an Application]}

(1) Extradition may be refused

a) if criminal proceedings are pending against the person sought in Germany for the same offence as the one on which the request is based,

b) if criminal proceedings against the person sought for the same offence as the one on which the request is based, have either not been instituted or if initiated have been closed,

c) if a request for extradition by a third State shall be given precedence,

d) unless on the basis of the duty to surrender under the Council Framework Decision ... on the basis of an assurance by the requesting State or based on other reasons it can be expected that the requesting State would honour a similar German request.

(2) Extradition of a foreign citizen normally living on German territory may further be refused

a) if in the case of an extradition for the purpose of prosecution the extradition of a German citizen would be inadmissible under s. 80(1) and (2),

b) if in the case of an extradition for the purpose of enforcement, after being judicially warned, the person sought does not consent on the record of the court and his interest in an enforcement in Germany prevails; s. 41(3) and (4) shall apply mutatis mutandis.

\subsubsection{The Presumption of Innocence}

2.3.1.1-2.3.1.2 The presumption of innocence as a particular manifestation of the principle of the rule of law laid out in Art. $20(3)^{134}$ of the GG was expounded by Judge Bro $\beta$ in his dissenting opinion in the BVerfG's European Arrest Warrant I decision on the first version of the implementation of the EAW Framework Decision in the IRG.

\section{Article 20 GG [Basic constitutional principles]}

(3) The legislature shall be bound by the constitutional order, the executive and the judiciary by law and justice.

He claimed that the presumption of innocence protected the person charged with a crime 'from all disadvantages that are equivalent to a verdict of guilt or a sentence but have not been preceded by proceedings intended to ascertain the person's guilt that have been conducted under the rule of law in compliance with the code of

${ }^{134}$ Also cf. above at Sect. 1.2.1. 
procedure'. ${ }^{135}$ Only proper main proceedings enable the judge to determine the guilt of the accused and only a final judgment in line with criminal procedural law could rebut the presumption of innocence. In his view, the EAW violates this principle since it treats the person charged with a crime in one of the Member States as if found guilty for the purpose of the extradition even though proper proceedings have not taken place. Interestingly, the appellant did not rely on this constitutional principle and the majority of the Federal Constitutional Court did not consider it in its decision either. Its main concerns were of a different nature. ${ }^{136}$ The Court did not criticise the Framework Decision itself. It only dealt with the question whether the constitutional rights of the Basic Law were respected with regard to the discretion EU law had left to the German Bundestag. ${ }^{137}$

First, it held that the basic right of German nationals in Art. 16(2) $\mathrm{GG}^{138}$ not to be extradited to a foreign country - unless the law provides otherwise for extraditions to Member States of the EU or to an international court and the rule of law is observed - was violated, since the former version of the IRG did not include the possibility to deny extradition in cases where the respective person was charged with a crime that did not have a substantial link to German territory, i.e. the conduct or its result occurred in Germany. In such cases German nationals were protected from extradition by Art. 16(2) GG and the rule of law. ${ }^{139}$ In other words, the Bundestag should have used the discretion left by the Framework Decision to comply with the German Constitution. It should be kept in mind that Judge Broß also criticised the violation of the presumption of innocence from the perspective of the Constitution's protection of citizenship, since the majority of the Court was not willing to extend it to offences with a significant connecting factor to a foreign country. But if taken seriously, the presumption of innocence as a general principle rooted in the rule of law must apply to all persons, not just German nationals.

Secondly, the IRG did and still does provide for a two-layered system ${ }^{140}$ in which the proceedings are divided between the court reviewing the admissibility and political authorities finally granting the extradition. Since the government

\footnotetext{
135 Judge Broß, Dissenting Opinion to the Judgment of the BVerfG, case 2 BvR 2236/04, European Arrest Warrant I, judgment of 18 July 2005, BVerfGE 113, 273, 323; concurring Ranft 2005 at para. 365 .

${ }^{136}$ Other constitutional questions were addressed as well, such as the 'integration clause' of Art. $23 \mathrm{GG}$ and the constitutional principles of Art. $20 \mathrm{GG}$; for a summary of the decision, see von Heintschel-Heinegg 2014, p. 666; Satzger 2012, § 8 para. 30; Sinn and Wörner 2007, p. 204.

${ }^{137} \mathrm{Cf}$. above at Sect. 1.3.4.

${ }^{138}$ The text of Art. 16(2) GG can be found above at Sect. 1.2.1.

${ }^{139}$ BVerfG, case 2 BvR 2236/04, European Arrest Warrant I, judgment of 18 July 2005, BVerfGE 113, 273, 304 et seq.

${ }^{140}$ This is in itself a violation of the EAW Framework Decision! Cf. von Bubnoff 2005, p. 63; Burchard 2013, § 14 para. 12; Hackner 2012, § 79 IRG para. 1; von Heintschel-Heinegg 2014, p. 670 ; Reinbacher 2014, p. 544.
} 
authorities were afforded a margin of discretion, in the Court's view, Art. 19(4) GG required that the decision be subject to a judicial review as well. ${ }^{141}$

\section{Article 19 GG [Restriction of Basic Rights - Legal Remedies] ${ }^{142}$}

(4) Should any person's rights be violated by public authority, he may have recourse to the courts. If no other jurisdiction has been established, recourse shall be to the ordinary courts. The second sentence of paragraph (2) of Article 10 shall not be affected by this paragraph.

Both aspects have now been accounted for in the new version of the IRG: Sect. 80 IRG distinguishes between offences with a substantial link to German territory and those with a substantial link to the requesting Member State, and Sect. 79(2) IRG provides for judicial review of the decision of the authority in charge as to whether it intends to raise objections under Sect. 83b IRG (Obstacles to Granting an Application).

Albeit the presumption of innocence did not play a major rule in the European Arrest Warrant I decision, the question whether German courts may review the facts and determine whether there is probable cause that the person sought has actually committed the crime he or she is charged with, is nevertheless debated among German scholars and courts. Section 10(2) IRG provides for a review of whether there are reasonable grounds to believe that the person sought has committed the crime if it is justified by 'special circumstances'.

\section{Section 10 IRG [Extradition Documents]}

(2) If special circumstances justify a review as to whether there are reasonable grounds to believe that the person sought has committed the offence with which he is charged, extradition shall be not granted unless a description of the facts showing probable cause for the commission of the offence has been submitted.

It is unclear, however, whether this provision is applicable to EAWs. Before the Framework Decision, this question was debated with regard to the European Convention on Extradition of 1957 as well. Since subject to Sect. 1(3) IRG international treaties take precedence over the regulations of the IRG, Sect. 10(2) IRG seemed not to apply as far as it followed from the respective treaty that there should be no review of the grounds for suspicion. ${ }^{143}$ Although the European Convention on Extradition generally did not provide for such a review, the Federal Court of Justice (Bundesgerichtshof, hereinafter BGH) held that a limited application of Sect. 10(2) IRG was possible in cases where there was evidence to believe that the requesting Member State acted abusively or where it was to be feared that the

${ }^{141}$ BVerfG, case 2 BvR 2236/04, European Arrest Warrant I, judgment of 18 July 2005, BVerfGE 113, 273, 309 et seq.

142 Translation of the GG by Christian Tomuschat and David P. Currie.

${ }^{143}$ Vogel 2014, § 10 IRG para. 69. 
extradited individual was exposed to a violation of fundamental rights and a review of the facts and grounds for suspicion could shed light on these apprehensions. ${ }^{144}$

Some courts ${ }^{145}$ and commentators ${ }^{146}$ argue that Sect. 10(2) IRG applies to EAWs as well, since subject to Sect. 78(1) IRG, other provisions of the Act shall apply to extraditions to Member States of the EU 'unless this Part contains specific regulations' - which in this regard it does not. What is more, Sect. 82 IRG specifically states that some provisions of the IRG do not apply to EAWs, but these do not include Sect. 10(2) IRG. The BVerfG demanded that the documents must be sufficient (Sect. 83a IRG) in order to determine the reasonable grounds for the suspicion but also considered Sect. 10(2) IRG as regards EAWs. ${ }^{147}$ The Higher Regional Court (Oberlandesgericht, hereinafter OLG) Köln limited the application of Sect. 10(2) IRG to cases where the criteria the BGH had introduced regarding the European Convention on Extradition (abuse or violation of fundamental rights) are fulfilled. ${ }^{148}$ It remains to be seen whether the application of Sect. 10(2) IRG is in line with the Framework Decision, ${ }^{149}$ which is based on mutual trust and does not include a review of the facts on which the suspicion is based. Additionally, Sect. 10 (2) IRG requires 'special circumstances' for such a test. The OLG Karlsruhe, for instance, accepted an alibi for the time of the offence confirmed by several witnesses as a ground for review. ${ }^{150}$

Other German courts and commentators refuse to apply Sect. 10(2) IRG in matters regarding EAWs. ${ }^{151}$ With the exception of Sect. 83a(1) No. 5 IRG, subject to which extradition shall not be admissible unless a description of the circumstances in which the offence was committed, including the time and place of its commission and the mode of participation by the person sought has been transmitted, Sects. 78-83i IRG do not include a review as to whether there are reasonable grounds for the suspicion. Therefore, some commentators interpret Sect. 83a IRG as a 'lex specialis' precluding the review of the reasonable grounds subject to Sect. 10(2) IRG. ${ }^{152}$ Moreover, the IRG must be interpreted in the light of the Framework Decision, which according to this view does not include a revision

\footnotetext{
${ }^{144}$ BGH, in: Neue Juristische Wochenschrift (NJW) 1984, p. 2048.

${ }^{145}$ OLG Karlsruhe, in: Strafverteidiger (StV) 2007, p. 650; Higher Regional Court Berlin (Kammergericht, hereinafter KG), in: Strafverteidiger Forum (StraFo) 2010, p. 191.

146 Von Bubnoff 2005, p. 22; Hackner 2012, § 78 IRG para. 14; Lagodny 2014, § 22 para. 50.

${ }^{147}$ BVerfG, case 2 BvR 2115/09, Auslieferungshaftbefehl, order of 9 July 2009, StraFo 2009, p. 460.

${ }^{148}$ OLG Köln, case 6 AuslA 84/11, order of 6 October 2011; concurring Burchard 2013, § 14 para. 51.

${ }^{149}$ Critical Böse 2014, § 83a IRG para. 1.

${ }^{150}$ OLG Karlsruhe, in: StV 2007, p. 650.

${ }^{151}$ OLG Stuttgart, in: StV 2004, p. 547; concurring Ahlbrecht and Lagodny 2003, p. 333; Böse 2013, § 83a IRG para. 12; critical Ranft 2005, p. 365.

${ }^{152}$ Böse 2013, § 83a IRG para. 13.
} 
of the facts. ${ }^{153}$ In 'extreme and exceptional cases', however, they would allow such a review due to a violation of Sect. 73 IRG ('ordre public'). ${ }^{154}$

\section{Section 73 IRG [Limitations on Assistance (Ordre Public)]}

Legal assistance and transmission of data without request shall not be granted if this would conflict with basic principles of the German legal system.

Requests under Parts VIII, IX and X shall not be granted if compliance would violate the principles in Article 6 of the Treaty on [the] European Union.

These thoughts lead us to an even more debated issue: The question whether German courts can refuse to issue an EAW on the grounds that the criminal prosecution or detention in the other Member State (and therefore the extradition of the suspect) would violate basic rights of the German or the European 'ordre public'. ${ }^{155}$ Sect. $73 \mathrm{cl}$. 1 IRG deals with the German 'ordre public'. Could an EAW therefore be denied on the grounds of a violation of the rights laid out in the Basic Law? Some German courts apply Sect. $73 \mathrm{cl}$. 1 IRG and deny extradition in extreme cases due to a violation of the German 'ordre public' ${ }^{156}$

However, this view is not in line with the prevailing view ${ }^{157}$ and the motives of the Bundestag. When enacting Sect. 73 cl. 2 IRG, which deals with the European 'ordre public', it stated that the German 'ordre public' was not applicable to EAWs, since the Framework Decision did not include such a ground for refusal. Instead, cl. 2 was meant to implement Art. 1(3) of the Framework Decision as a special law for EAWs ${ }^{158}$ which is expressed in the phrase 'Requests under Parts VIII, IX and X'. Therefore, cl. 2 is the exclusive provision for EAWs. ${ }^{159}$ This reflects the primacy of EU law, ${ }^{160}$ particularly in the light of the CJEU decision in Melloni ${ }^{161}$ However, this could still mean that EAWs can be denied subject to Sect. $73 \mathrm{cl} .2$ IRG if there is a

153 Ibid.
154 Ibid.

155 Cf. Gaede 2013, p. 1279; Reinbacher 2014, pp. 542-544.

156 OLG Celle, in: BeckRS 2008, No. 10354 (life imprisonment for possession of small amount of soft drugs violates principle of proportionality); OLG Hamm, in: StV 2011, p. 173 (extradition violates protection of marriage and family).

157 Vogel 2014, § 73 para. 139. Also cf. Ambos and Poschadel 2015, § 73 para. 65: cl. 1 regards international cooperation but is only applicable if there are no directly applicable provisions of an international treaty which take precedence subject to Sect. 1(3) IRG; cl. 2 regards cooperation within the EU.

158 Bundestag Printed Paper (Bundestagsdrucksache, hereinafter BT-Drs.) 15/1718, pp. 11, 14.

159 Burchard 2013, § 14 para. 47; Vogel 2014, § 73 IRG paras. 10, 139. Vogel 2014, § 73 para. 136 rightly points out that Sect. $73 \mathrm{cl}$. 2 IRG therefore should have been placed in Part VIII of the IRG among the provisions dealing with extradition in the EU instead.

${ }^{160}$ Cf. Ambos and Poschadel 2015, § 73 para. 65: German basic rights not applicable due to primacy of EU law; Böse 2014, Vor $\S 78$ para. 26: German basic rights have been replaced by the European ordre public unless the Framework Decision leaves a margin of discretion.

${ }^{161}$ Case C-399/11 Melloni [2013] ECLI:EU:C:2013:107, para. 59: 'Rules of national law, even of a constitutional order, cannot be allowed to undermine the effectiveness of EU law on the territory of that State.' 
violation of the principles of Art. 6 TEU, so that for instance Art. 6(2) of the European Convention on Human Rights (ECHR) could be invoked with regard to the presumption of innocence in accordance with Sect. $73 \mathrm{cl} .2$ IRG.

However, since the CJEU decisions Melloni ${ }^{162}$ and $\mathrm{Radu}^{163}$ it has become unclear whether Sect. 73 cl. 2 IRG is in line with EU law. ${ }^{164}$ Some interpretations of these judgments go so far as to assume that the CJEU would only accept a refusal of an EAW on the grounds laid out in Arts. 3-5 of the Framework Decision. ${ }^{165}$ Others point out that the Court did not specifically say that a violation of the principles of Art. 6 TEU did not count as a ground for refusal, and that on the contrary, Art. 1(3) of the Framework Decision demands that the European 'ordre public' itself be respected. ${ }^{166}$ It should also be noted that European law, including the Framework Decision, must be interpreted in the light of the Charter of Fundamental Rights of the EU, ${ }^{167}$ which the Member States must respect pursuant to Art. 51 of the Charter 'when they are implementing Union law'. What is more, all EU Member States are bound by the ECHR, so that individuals can ultimately apply to the European Court of Human Rights (ECtHR) pursuant to Art 34 ECHR in the case of a violation of the Convention by the extraditing state.

Most German commentators argue in favour of Sect. 73 cl. 2 IRG. ${ }^{168}$ They claim that even though German law is to be interpreted in the light of EU law and even if the CJEU actually interprets the Framework Decision differently, there must not be an interpretation of the German provision contra legem, i.e. against the wording of Sect. 73 cl. 2 IRG. ${ }^{169}$ Furthermore, if the core of the European 'ordre public' were not respected, some commentators hold that the German Federal Constitutional Court could then evoke the emergency jurisdiction it has reserved for an identity review in exceptional circumstances, ${ }^{170}$ since fundamental rights would no longer be protected. Some German courts also apply Sect. $73 \mathrm{cl} .2$ IRG and consider a violation of Art. 6 TEU as a reason for denial to execute an EAW. ${ }^{171}$

\footnotetext{
162 Case C-399/11 Melloni, n. 161.

163 Case C-396/11 Radu [2013] ECLI:EU:C:2013: 39.

${ }_{164}$ Ambos and Poschadel 2015, § 73 paras. 70-76; Burchard 2013, § 14 para. 49; Heger and Wolter 2015, Art. 1 RbEuHb para. 644; Reinbacher 2014, pp. 543-544; Vogel 2014, § 73 IRG paras. 137-138.

165 Brodowski 2013, p. 56, pointing out that a conflict between the CJEU and BVerfG might arise.

${ }^{166}$ Burchard 2013, § 14 para. 49; also cf. Inhofer 2015, § 79 IRG para. 1.

167 Ambos and Poschadel 2015, § 73 IRG para. 73.

${ }^{168}$ Ambos and Poschadel 2015, § 73 IRG paras. 70-76; Böse 2014, Vor $\S 78$ para. 25; Inhofer 2015, § 79 para. 1, referring to Case C-105/03 Pupino [2005] ECR I-05285, para. 47: ‘... the principle of conforming interpretation cannot serve as the basis for an interpretation of national law contra legem'.

169 OLG München, in: StV 2013, p. 710; Burchard 2013, § 14 para. 47.

${ }^{170}$ Gaede 2013, p. 1280; also cf. Brodowski 2013, p. 56; on the judicial reservations in exceptional circumstances, cf. supra at Sect. 1.3.4.

${ }^{171}$ Recent decisions: OLG Karlsruhe, in: BeckRS 2014, No. 11797; OLG München, in: StV 2013, p. 710; OLG Stuttgart, in: NJW 2010, p. 1617.
} 
Very recently the BVerfG actually decided on the matter of human rights and the EAW. ${ }^{172}$ When assessing an EAW and the extradition of an American citizen from Germany to Italy, the Court relied upon the inviolability of human dignity arising from Art. 1(1) GG, and invoked its identity review to claim jurisdiction over the case. ${ }^{173}$ The accused had been convicted in absentia ${ }^{174}$ in Italy and claimed that he had not had any knowledge of the proceedings and would not be granted a proper (re-)trial including a hearing of evidence in Italy, even though Sect. 83 No. 3 IRG of 2006 demanded 'a trial de novo in which the charges against him will be reviewed in their entirety and where he will be given the right to be present at the trial'. The OLG Düsseldorf, however, relied on the information from the Italian Prosecutor's Office that the accused would be granted a restoration to the (missed) deadline for an appeal, and therefore held that a proper review of the case including a new hearing of evidence could not be ruled out. The BVerfG decided that the OLG had failed its obligation to investigate the matter further as to whether there would in fact be a proper hearing of evidence in the new trial. The Court explained that German courts always have to respect Art. 1(1) GG when issuing EAWs. ${ }^{175}$ The BVerfG stated, however, that the limitations on extradition imposed by EU law requirements were identical to the limitations arising from Art. 1(1) GG. ${ }^{176}$ As regards the IRG, the Court declared that regardless of the actual meaning of Sect. $73 \mathrm{cl} .2$ IRG (which it left open), this provision did not prevent German courts from respecting Art. 1(1) GG when they interpret Sects. 78-83i IRG. ${ }^{177}$

\subsubsection{Nullum Crimen, Nulla Poena Sine Lege}

2.3.2.1 In the European Arrest Warrant I decision of 2005 the BVerfG also turned to Art. 103(2) GG. ${ }^{178}$

\section{Article 103 GG [Fair Trial]}

(1) In the courts every person shall be entitled to a hearing in accordance with law.

(2) An act may be punished only if it was defined by a law as a criminal offence before the act was committed.

172 BVerfG, case 2 BvR 2735/14, European Arrest Warrant II, order of 15 December 2015. This decision was delivered long after this report was finalised and could therefore only be considered briefly.

${ }^{173}$ Cf. Sect. 1.3.4.

${ }^{174}$ For in absentia judgments and the EAW, cf. Sect. 2.3.3.

${ }^{175}$ BVerfG, case 2 BvR 2735/14, European Arrest Warrant II, order of 15 December 2015, para. 83.

176 Ibid., para. 84.

${ }^{177}$ Ibid., para. 108.

${ }^{178}$ BVerfG, case 2 BvR 2236/04, European Arrest Warrant I, judgment of 18 July 2005, BVerfGE 113, 273, 308. 
(3) No person may be punished for the same act more than once under the general criminal laws.

Subject to this provision an act may only be punished if it was defined by law as a criminal offence before the act was committed. The Court again considered this principle from the perspective of Art. 16(2) GG, which permits the extradition of German nationals only if 'the rule of law is observed'. The Court reported correctly that the principle of nulla poena sine lege as enshrined in Art. 103(2) GG only applies to substantive criminal law and not to procedural law - to which the laws on extradition in Germany belong. ${ }^{179}$ The Court argued, however, that if a German citizen were answerable for acts that did not have a significant connecting link to a foreign country and were not punishable crimes in Germany when they were committed, 'this could be tantamount to a retroactive amendment of substantive law'.

Again, it must be pointed out that the Court was merely concerned about acts committed primarily in Germany. This is indeed a convincing perspective, ${ }^{180}$ for if a person commits an act in a foreign country, which constitutes a punishable crime under the law of that country, the problem of nulla poena does not arise, since the respective criminal laws existed at the time of the act in the state where it was committed. The situation is much more problematic, however, if foreign laws apply even when the person physically acts in a country (e.g. his or her own) where the act is not a punishable offence. There are certain conditions under which criminal laws can extend to foreign countries, e.g. either because both the act and the result are considered as a 'place of the offence' - as provided for in Sect. 9(1) of the German Criminal Code (Strafgesetzbuch, hereinafter StGB) - and these two places differ, or because other principles, such as the active or passive personality principle, apply. ${ }^{181}$

Consequently, a situation can arise where a person's behaviour is perfectly in line with the laws of the country where he or she physically acts (and resides), whereas it may at the same time constitute an offence in a different country. This is for instance quite common when crimes are committed on the internet where laws of multiple jurisdictions can apply. German scholars have repeatedly given the example of Sect. 130(3) StGB, which makes it a punishable act to publicly deny or downplay any act committed under the rule of National Socialism in Germany - a particularity of German criminal law. ${ }^{182}$ In theory, such an act could be prosecuted in Germany if it were committed online, even if the person charged with the offence physically acted in a different country that does not criminalise such behaviour. ${ }^{183}$

\footnotetext{
179 Ibid.

${ }^{180}$ Reinbacher 2014, p. 536.

181 Cf. Deiters 2003, p. 360; Reinbacher 2014, p. 610.

182 Cf. Deiters 2003, p. 360; Reinbacher 2014, pp. 610, 616-618; Schünemann 2003, p. 188.

183 This was actually the case in the BGH's famous Toeben decision; BGH, case 1 StR 184/00, judgment of 12 December 2000, in: NJW 2001, p. 624.
} 
With the EAW in force, the extradition of nationals of other EU states to Germany with regards to this particular crime becomes a possibility.

While some German scholars argue that the most punitive laws will thereby become applicable in the entire $\mathrm{EU}^{184}$ and claim that the democratic principle - and the (constitutional) laws that prevent a country from extraditing its own nationals imply that no one shall be punished for an offence in the enactment of which he did not participate by way of the democratic process, the problem actually predominantly arises when an act is committed in the person's own country. When acting abroad there are good reasons why foreign laws should apply because everyone has to respect the (criminal) laws of the country the person is in, regardless of the fact that the person could not vote for the parliament that enacted them. Therefore, the questions whether and when national criminal laws apply become crucial. This could lead to a broad discussion of a matter which is still far from being solved if there were enough space to elaborate on it - in short: whether and when there are reasonable grounds for a state to apply its criminal laws in relation to an act. ${ }^{185}$

With regards to the EAW, however, the BVerfG has excluded the admissibility of extraditions in cases that are not significantly connected to the country that seeks the extradition, and Sect. 80 IRG now implements this requirement. Subject to Sect. 80(1) cl. 1 No. 2 IRG, Germany does not extradite German citizens unless the offence has a substantial link to the requesting Member State, and cl. 2 elaborates that such a substantial link exists if the conduct underlying the offence occurred wholly or in its essential parts on its territory and the result occurred there at least to an essential degree, or if it relates to a serious offence with a typical cross-border quality which was committed at least in part on its territory. If these conditions are not fulfilled, Sect. 80(2) IRG requires that the act be an offence under German law as well. On the other hand, the catalogue of offences that do not need to be an offence under German law if there is a necessary link to another Member State has been fiercely criticised in the light of the principles of clarity and certainty, ${ }^{186}$ particularly because the wording has been deemed to be much too broad. ${ }^{187}$

However, the crucial point with regards to the nulla poena principle is that the Member State that seeks the extradition must have established sufficient criminal laws before the act was committed. ${ }^{188}$ As regards the European 'ordre public' (Sect. 73 cl. 2 IRG), the requirements are not as strict as in Art. 103(2) GG, since common law is a sufficient source as well, so that an Act of the respective parliament is not necessary. ${ }^{189}$

\footnotetext{
${ }^{184}$ Schünemann 2003, p. 188; Schünemann 2007, p. 532.

${ }^{185}$ German law treats the question of the applicability of German criminal law as a part of substantive criminal law in Sects. 3-9 StGB, whereas in other legal systems it is a question of criminal procedural law.

${ }^{186}$ Schünemann 2003, p. 188; cf. von Bubnoff 2005, p. 10; Satzger 2012, § 8 para. 26.

${ }^{187}$ Schünemann 2003, p. 188: 'a catalogue of key words'; also cf. Satzger 2012, § 8 para. 26: 'offences only outlined roughly'.

${ }^{188}$ Conrad 2013, p. 192; Heger 2007, p. 224.

${ }^{189}$ Vogel 2014, § 73 IRG para. 60.
} 


\title{
2.3.3 Fair Trial and In Absentia Judgments
}

2.3.3.1 It should first be noted that German criminal procedural law in general bans in absentia judgments, cf. Sect. 230(1) of the German Code of Criminal Procedure (Strafprozessordnung, hereinafter StPO) ${ }^{190}$ so that the respective problem does not arise for EAWs issued in Germany.

Section 230 StPO [Failure of the Defendant to Appear] ${ }^{191}$

(1) No main hearing shall be held against a defendant who fails to appear.

The rules relating to EAWs issued by other Member States that permit in absentia judgments are provided for in Sect. 83(1) No. 3 IRG. Subject to this provision, extradition from Germany shall not be admissible if, in the case of a request for the purpose of enforcement of a sentence, the convicted did not appear in person at the trial which resulted in the decision. This provision implemented not only the original Framework Decision but also the view of the BVerfG, which ruled that in absentia judgments violate basic principles of German constitutional law and of international law, e.g. the principle of fair trial subject to Art. 103(1) GG (right to a hearing in the courts) and Art. 6(3) ECHR, or human dignity subject to Art. 1(1) GG, ${ }^{192}$ unless certain criteria are met. ${ }^{193}$ The Court held, however, that an extradition was admissible if the accused had fled from trial in the "knowledge of the proceedings' and defence counsel had been appointed and able to defend the accused in line with the rule of law. ${ }^{194}$ Accordingly, subject to the former Sect. 83 No. 3 IRG of 2006 extradition was not admissible

\begin{abstract}
if in the case of a request for the purpose of enforcement the sentence on which the request is based was issued in absentia and the person sought had not been personally summoned to or otherwise been informed about the date of the hearing which led to the judgment in absentia unless the person sought, in a case where defence counsel had been appointed, frustrated the service of a summons through flight in the knowledge of the proceedings against him, or if after his transfer he is granted a trial de novo in which the charges against him will be reviewed in their entirety and where he will be given the right to be present at the trial.
\end{abstract}

\footnotetext{
190 There are a few exceptions to this general rule provided for in Sect. 231 et seq., 408a and the new 329(2) StPO, which are beyond the scope of this report.

${ }^{191}$ Translated by Brian Duffett and Monika Ebinger.

192 The text of Art. 1 GG can be found above in Sect. 1.2.1.

${ }^{193}$ Cf. BVerfG, case 2 BvR 283/05, order of 4 July 2005, in: Neue Zeitschrift für Strafrecht (NStZ) 2006, para. 102; also cf. BVerfG, case 2 BvR 2735/14, European Arrest Warrant II, order of 15 December 2015.

${ }^{194}$ BVerfG, case 2 BvR 1255/86, order of 17 November 1986, in: NJW 1987, p. 830; BVerfG, case 2 BvR 1704/90, order of 24 January 1991, in: NJW 1991, p. 1411; BVerfG, case 2 BvR 26/ 04, order of 3 March 2004, in: Neue Zeitschrift für Strafrecht Rechtsprechungsreport (NStZ-RR) 2004, p. 308
} 
Section 83 IRG was amended in 2015 in order to implement Art. 4a of the Framework decision. Its new wording is almost identical to the wording of the respective EU legislation.

The new Sect. 83(2) No. 2 IRG still allows extraditions in cases where the accused frustrated the service of a summons through flight 'in the knowledge of the proceedings' if defence counsel had been appointed. This was also the case under the version of 2006, whereas under the former provision of 2004 extradition was not admissible even in cases of flight, unless the accused had been personally 'summoned to' or otherwise been 'informed about the date of the hearing', so that knowledge of the proceedings as such was not sufficient. ${ }^{195}$ In other words: the extradition of a fugitive from justice was not admissible if he or she did not have knowledge of the actual date of the hearing. ${ }^{196}$ During the legislative procedure after the European Arrest Warrant I decision, the Bundesrat was critical of the fact that extradition to Member States of the EU was thereby more difficult than to other states, since the BVerfG had allowed extradition in cases of flight if the accused had knowledge of the proceedings as such. ${ }^{197}$ The amendment followed the Bundesrat's objections.

The 2006 version of Sect. 83 IRG was enacted before Art. 4a of the Framework Decision came into force. Yet still, according to the most convincing view, it had to be read together with Art. 4a of the Framework Decision which thereby complemented the German provision. ${ }^{198}$ Some problems stemming from the different wording have now been solved. For instance, the former Sect. 83 No. 3 IRG of 2006 allowed extradition after an in absentia judgment if the accused had 'otherwise been informed' of the date of the hearing, whereas Art. 4a of the Framework Decision demands that the accused has 'actually received official information' and has been informed that a decision may be handed down if he or she does not appear for the trial. While some courts and commentators would simply rely on the wording of the former Sect. 83 No. 3 IRG and accept any kind of knowledge of the date of the hearing, ${ }^{199}$ the OLG Oldenburg held that these requirements must be read into the German provision. ${ }^{200}$ The new Sect. 83(2) No. 1 (a) (bb) now demands 'official information'.

Before the EAW was introduced, the BVerfG and the BGH held that the right to appear before a court was an integral part of the fair trial principle, Art. 103(1) GG, and of the right to human dignity, Art. 1(1) GG, and did therefore not allow the extradition if this right was violated. ${ }^{201}$ It has been the constant view of the BVerfG

\footnotetext{
195 OLG Karlsruhe, in: StV 2004, p. 548; Hackner 2005, p. 313.

${ }^{196}$ OLG Karlsruhe, in: StV 2004, p. 548.

197 BT-Drs. 16/1024, p. 23.

198 OLG Oldenburg, in: BeckRS 2013, 16497.

${ }^{199}$ OLG Karlsruhe, in: StV 2004, p. 548; Hackner 2012, § 83 IRG para. 6.

${ }^{200}$ OLG Oldenburg, in: BeckRS 2013, No. 16497.

${ }^{201}$ BVerfG, case 2 BvR 1704/90, order of 24 January 1991, in: NJW 1991, p. 1411; BGH, in: NJW 2002, p. 228.
} 
that the unalterable parts of the Basic Law have to be respected in cases of extradition, which it has particularly claimed in cases of in absentia judgments. ${ }^{202}$ As explained above, the 'ordre public' is provided for in Sect. 73 IRG. But since Sect. 83 IRG is a special provision that specifically deals with in absentia judgments so that subject to the wording of Sect. 78 IRG other provisions do not apply, some German courts have ruled that extraditions in cases of in absentia judgments are only to be assessed subject to Sect. 83 IRG when dealing with EAWs, i.e. Sect. 73 IRG is not applicable. ${ }^{203}$ Some commentators agree and interpret Sect. 83 IRG as a 'lex specialis' compared to Sect. 73 IRG. ${ }^{204}$ However, since in absentia judgments may be unconstitutional not only from the perspective of the Basic Law but may also violate basic principles of international ${ }^{205}$ and European law, such as Art. 6(3) ECHR, ${ }^{206}$ other commentators would still rely on the principles of Sect. $73 \mathrm{cl} .2$ IRG as a residual provision, arguing that the European 'ordre public' was meant to be the basic standard for all EAW procedures, ${ }^{207}$ or would at least interpret Sect. 83 IRG in the light of the European 'ordre public'. ${ }^{208}$ This would mean, for instance, that proceedings in absentia must comply with the rule of law. ${ }^{209}$ When introducing the Bill for the 2015 version of Sect. 83 IRG the German Government explained that Sect. $73 \mathrm{cl}$. 2 IRG contains a general provision to respect the European 'ordre public', so that, for instance, it was not necessary to include the proviso in Sect. 83 IRG that the convicted person be informed of the trial in a language he or she understands, since the right to an interpreter is a minimum right subject to Art. 6(3)(e) ECHR. ${ }^{210}$

Again, the BVerfG's recent European Arrest Warrant II decision shed some light on the Court's view on the matter - even though it regarded the 2006 version of Sect. 83 IRG. As explained above in Sect. 2.3.1, the Court stated that German courts must always respect Art. 1(1) GG (and interpret the IRG accordingly). ${ }^{211}$ In cases of in absentia judgments the courts must therefore, for instance, investigate whether there will be a proper trial in the requesting state, including the hearing of evidence - if there are substantial reasons to doubt it.

\footnotetext{
202 BVerfG, case 2 BvR 315/83, order of 9 March 1983, in: NJW 1983, 1726; case 2 BvR 1704/ 90, order of 24 January 1991, in: NJW 1991, p. 1411.

${ }^{203}$ OLG Stuttgart, in: NStZ-RR 2008, p. 176.

${ }^{204}$ Ambos and Poschadel 2015, § 73 para. 91.

${ }^{205}$ Cf. BVerfG, case 2 BvR 26/04, order of 3 March 2004, NStZ-RR 2004, 308, 309, arguing that the core of the respective right is also a basic standard of international law, which is incorporated into German law subject to Art. 25 GG.

${ }^{206}$ Cf. ECtHR, Colozza v. Italy, 12 February 1985, Series A no. 89.

${ }^{207}$ Vogel 2014, § 73 IRG para. 140.

${ }^{208}$ Böse 2013, § 83 IRG para. 15.

${ }^{209}$ Ibid.

${ }^{210}$ BT-Drs. $18 / 3562$, pp. 80 et seq.

${ }^{211}$ Ibid., para. 110.
} 


\subsubsection{Fair Trial and Practical Challenges Regarding a Trial Abroad}

2.3.4.1 Many German scholars argue that if an issuing Member State does not comply with the rule of law during the proceedings, extradition can then be denied subject to Sect. 73 IRG, as explained above at Sect. 2.3.1. As regards extradition proceedings in Germany, the basic defence rights under the IRG apply. The person sought may at any time have the assistance of counsel (Sect. 40 IRG), he or she has the right to remain silent and must be informed of these rights (Sect. 21(2) IRG). Under certain circumstances counsel will be assigned to the person sought subject to Sect. 40(2) IRG: '1.) if due to the factual or legal complexity of the case assistance appears appropriate, in proceedings according to paragraph 2 of Part VIII, especially in cases of doubt whether the conditions of Sects. 80 and 81 no. 4 have been fulfilled; 2.) if it is apparent that the person sought cannot himself adequately protect his rights; or 3 ) if the person sought is under 18 years of age'. Additionally, subject to Sect. 77 IRG, the rules of criminal procedure of the StPO apply as well.

On the other hand, as was explained above, German courts usually do not review the grounds for the suspicion or the lawfulness of the foreign decision, unless Sects. 10(2), $73 \mathrm{cl}$. 2 IRG apply in 'special circumstances', and therefore defence in the requesting state becomes necessary. ${ }^{212}$ Some commentators argue that in order to comply with the rule of law, German authorities need to permit an undisturbed and unlimited communication between the accused and his or her defence counsel abroad. ${ }^{213}$ It is not easy, however, to find counsel in a foreign country if for instance the person sought is not a national of the requesting state and is located in Germany. The German Association of Criminal Defenders maintains contacts with similar associations in foreign countries, ${ }^{214}$ and big law firms may have branches abroad. Yet generally the accused must take these measures into his or her own hands. Some scholars have therefore demanded the establishment of an organisation on the EU level funded by the EU called 'Eurodefensor' as a pendant to Eurojust, meant to provide assistance for criminal defenders in cases with a trans-border dimension. ${ }^{215}$

Among the many questions regarding the practical challenges of extradition procedures, two further aspects shall briefly be dealt with: the costs of the proceedings and compensation for wrongful imprisonment. With regard to the costs of the proceedings, subject to Sect. 77 IRG, the respective provisions of the StPO apply, mainly Sects. 467,467 a StPO. In practice, this means in particular that the German state will bear the necessary costs of a chosen defence counsel if the person sought does not consent to the extradition, requests a court decision subject to Sect. 29 IRG and the court then decides in his or her favour. ${ }^{216}$

\footnotetext{
212 Vogel and Burchard 2014, § 77 IRG para. 43.

213 Ibid.

${ }^{214} \mathrm{http}: / /$ deutsche-strafverteidiger.de/kontakt/auslandskontakt.html.

${ }^{215}$ Schünemann 2004, p. 14; also cf. Reinbacher 2014, p. 622.

${ }^{216}$ Vogel and Burchard 2014, § 77 IRG para. 66.
} 
Compensation for wrongful imprisonment in Germany is granted subject to the provisions of the Compensation for Prosecution Act (Gesetz über die Entschädigung für Strafverfolgungsmaßnahmen, hereinafter StrEG), which generally only applies to imprisonment in Germany. Furthermore, Sect. 77 IRG does not refer to the StrEG, thereby excluding its applicability to measures regarding extradition, so that even in the case of wrongful extradition detention in Germany, compensation will not be paid if arrest and detention were stipulated by a foreign country and German authorities were not responsible for the wrongful accusation and imprisonment. ${ }^{217}$ This means that the affected person has a claim for compensation against the German state solely for the wrongful actions of German authorities. However, subject to Sect. 2(3) StrEG, compensation will also be granted for extradition detention or measures of search and seizure abroad if stipulated by German authorities. Apart from this, compensation for wrongful imprisonment in other Member States will not be granted. ${ }^{218}$

\subsubsection{The Right to Effective Judicial Protection: The Principle of Mutual Recognition in EU Criminal Law and Abolition of the Exequatur in Civil and Commercial Matters}

2.3.5.1-2.3.5.2 The transfer of the principle of mutual recognition to the field of criminal law, which also underlies the concept of the EAW, has been the object of a controversial discussion in Germany. Some scholars point out that the principle was in itself a 'neutral concept ${ }^{219}$ since it meant integration instead of cooperation and also provided positive effects for the accused, such as the principle of ne bis in idem by recognising foreign court decisions. Other commentators, however, harshly criticise the concept. ${ }^{220}$ They claim that whereas in the Single European Market the principle of mutual recognition meant an expansion of freedom, in the field of criminal law it meant a limitation of freedom. Some scholars state that the mechanism of mutual recognition could "cause fundamental defensive rights to go astray'. ${ }^{221}$ The recognition of evidence as a 'marketable good' in particular is deemed to be the cause for a reduction of defensive rights, ${ }^{222}$ since it led to a 'rag rug' of laws undermining the balance of the respective procedural laws. What is more, some commentators claim that market liberalisation and laws on the free movement of goods, etc., usually contain exceptions in order to respect

${ }^{217}$ BGH, in: NJW 1984, p. 1310; OLG Hamm, in: BeckRS 2009, No. 08021; OLG Köln, in: NStZ-RR 2006, p. 151; Vogel and Burchard 2014, § 77 IRG para. 63.

${ }^{218}$ OLG Düsseldorf, in: NStZ 1988, p. 371.

219 Böse 2014, Vor § 78 para. 19; Gleß 2004, p. 356; Vogler 1989, p. 254.

${ }^{220}$ Braum 2009, p. 419; Hecker 2015, § 12 para. 63; Satzger 2012, § 8 para. 24; Schünemann 2003, p. 187.

${ }^{221}$ Satzger 2012, § 8 para. 24.

${ }^{222}$ Gleß 2004, p. 365; Hecker 2015, § 12 para. 64. 
considerations of the 'ordre public' of the Member States, whereas in the field of criminal law such reservations are missing. ${ }^{223}$

Here again we reach the crucial question, which has already been dealt with in Sect. 2.3.1 and Sect. 2.3.3: do national courts simply have to execute the decisions of other Member States or can they review the decisions as to whether there is a violation of the national or the European 'ordre public'? As a short reminder, the Bundestag stated that only the European 'ordre public' as provided for in Sect. $73 \mathrm{cl}$. 2 IRG was to be taken into account when executing EAWs. Even though some would argue that it has even become unclear whether Sect. $73 \mathrm{cl}$. 2 IRG is in line with European law since the CJEU's decisions in Melloni and Radu seem to indicate otherwise, German courts still rely both on cl. 1 and $\mathrm{cl}$. 2 when dealing with EAWs. As regards cl. 1, German courts have, for instance, denied an extradition due to bad conditions of detention in the requesting Member State which violated fundamental rights, ${ }^{224}$ due to a violation of the principle of proportionality (of the sentence) as an integral part of the rule of $\operatorname{law}^{225}$ and because an extradition would mean a violation of Art. 6 GG, according to which '[m]arriage and the family shall enjoy the special protection of the state'. 226

While these decisions are criticised since they rely on Sect. $73 \mathrm{cl}$. 1 IRG and the Basic Law, other decisions reach similar conclusions by relying on cl. 2 . In this regard courts have examined whether the conditions of detention ${ }^{227}$ or the repeal of parole in absentia ${ }^{228}$ complied with the fundamental rights protected by the ECHR, or whether the sentence was unbearably harsh. ${ }^{229}$ This is the most interesting point, since the courts must find a way to reconcile the concept of mutual recognition with the fundamental rights of the accused, which has been the underlying question of this entire report.

On the one hand the concept of mutual recognition would be dead if every national court generally had the right to question and review the decisions of the courts of other Member States. Indeed it cannot be denied that a more intense form of cooperation is necessary when borders vanish and citizens can move freely between states. As the EU has become more integrated, it seems to be only natural that the field of criminal law cannot be spared as a 'reservation of national law'. ${ }^{230}$ Furthermore, it was a clear decision of the EU 'legislator' to establish mutual recognition in the field of criminal law and to introduce the EAW as a significant step. This EU policy must not be undermined by the courts of the Member States.

\footnotetext{
${ }^{223}$ Satzger 2012, § 8 para. 24.

${ }^{224}$ OLG Bremen, in: BeckRS 2014, No. 10396; OLG Hamm, in: NStZ-RR 2014, p. 228.

${ }^{225}$ OLG Celle, in: BeckRS 2008, No. 0354.

${ }^{226}$ OLG Hamm, in: StV 2011, p. 173.

227 OLG Karlsruhe, in: BeckRS 2014, No. 11797; OLG München, in: BeckRS 2015, No. 18224.

${ }^{228}$ OLG München, in: StV 2013, p. 710; Sect. 83 No. 3 IRG was not applicable since the original conviction had not been an in absentia judgment.

${ }^{229}$ OLG Stuttgart, in: NJW 2010, p. 1617.

${ }^{230}$ Satzger 2012, § 7 para. 2.
} 
Therefore, it must generally be accepted that the review of foreign decisions is not what the EU institutions had in mind, since this could invalidate the entire concept of mutual recognition.

On the other hand, one must not be blind towards the fact that there are still huge differences both in the law and in the conditions of detention in the Member States. Clearly, one could argue that it would be preferable to assimilate the substantive and procedural criminal laws of the Member States before mutual recognition can be enforced. In comparison, mutual recognition of criminal court decisions is a common thing in the Federal Republic of Germany, and Bavarian courts certainly recognise the decisions and arrest warrants of Hessian courts. But both German states have the same Penal and Procedure Code, since criminal law is almost entirely federalised in Germany. The situation is still very different within the EU. However, one should also keep in mind that the European 'ordre public' is a common base for all Member States. The logic of mutual recognition implies that because all criminal law systems within the EU are based on the fundament of the ECHR, mutual trust becomes possible. In other words: simply because all Member States have to respect the European 'ordre public' they can trust one another without any review of their respective decisions. ${ }^{231}$ Therefore, mutual recognition is built on a presumption of compliance with fundamental rights. Yet still, unfortunately this does not mean that these rights are actually respected in all cases. In this regard Sect. $73 \mathrm{cl}$. 2 IRG reveals the scepticism of the Bundestag towards the concept of mutual recognition. ${ }^{232}$

The German courts therefore seek to find a way that is 'friendly' towards Europe but also protects fundamental rights: in general judgments of other Member States must be accepted and enforced, so that there is no review of the grounds for suspicion or of the lawfulness of the proceedings or the sentence, but in cases of evident violations of fundamental rights in the requesting Member State, the courts apply Sect. 10(2) IRG or deny extraditions subject to Sect. 73 IRG, so that they for instance need not expose extradited citizens knowingly to very bad conditions in other Member States. In other words: the presumption of compliance can be rebutted in special circumstances.

Allowing the extraditing state such a test of compliance with the European 'ordre public' means shifting from the protection of human rights in the requesting state to a 'preventive protection' in the extraditing state. If one bears in mind both the fact that the requesting state is actually responsible for the violation of fundamental rights and that the concept of mutual recognition generally does not allow a review in the extraditing state, such preventive protection must be limited to exceptional cases. It has rightly been pointed out that the debate therefore needs to focus on finding criteria as to when such a situation actually arises. ${ }^{23}$ The prerequisites in the field of EAWs have yet to be clarified. Even though the ECtHR and

\footnotetext{
${ }^{231}$ Vogel 2014, § 73 IRG para. 133.

232 Ibid., para. 134.

${ }^{233}$ Burchard 2013, § 14 para. 51.
} 
the CJEU might develop a different approach and perspective as regards the 'preventive protection' of human rights, it is interesting to highlight that both courts require 'substantial grounds' to believe that the person will be exposed to violations of human rights. ${ }^{234}$ Another crucial matter that then naturally needs to be resolved is the question of the onus of proof of such a violation. ${ }^{235}$

The BVerfG's recent European Arrest Warrant II decision again contains some interesting aspects in this regard. The Court pointed out that Member States must not assist one another in violations of human rights. ${ }^{236}$ Therefore, German courts must look into the treatment that awaits the extradited person in the requesting state. The Court specifically mentioned in absentia judgments. ${ }^{237}$ This means that in the Court's view the concept of mutual trust is only valid as long as it is not rebutted in the individual case. ${ }^{238}$ This, however, requires an exceptional case. ${ }^{239}$ Applying its view in matters of international cooperation, the Court stated that a binding international agreement that the requesting state will respect human rights is enough to dispel such doubts. ${ }^{240}$ Furthermore, the accused must give sufficient and concrete evidence of the violations (of human dignity) in the individual case. It does not suffice for the accused to point out that the requesting state violated human rights in

\footnotetext{
${ }^{234}$ Opinion of A.G. Sharpston in Case C-396/11 Radu [2012] ECLI:EU:C:2012:648, para. 77; cf. ECtHR, Soering v. the United Kingdom, 7 July 1989, Series A no. 161 regarding an extradition from the UK to the USA, and CJEU, Joined cases C-411/10 and C-493/10 N.S. and Others [2011] ECR I-13905 regarding the Common European Asylum System but demanding 'systemic flaws'; also cf. Art. 3(2) of the Regulation (EU) No 604/2013 of the European Parliament and of the Council [2003], OJ L 180/31 (Dublin III): '... substantial grounds for believing that there are systemic flaws in the asylum procedure and in the reception conditions'; emphasis added by Tobias Reinbacher.

${ }^{235}$ Cf. the Opinion of A.G. Sharpston in Case C-396/11 Radu, n. 232, paras. 78-85, suggesting an approach differing from the one followed by the ECtHR: The requested person 'must persuade the decision-maker that his objections to the transfer are substantially well founded'.

${ }^{236}$ BVerfG, case 2 BvR 2735/14, European Arrest Warrant II, order of 15 December 2015, para. 62.

${ }^{237}$ Ibid., para. 69.

${ }^{238}$ Ibid., para. 68.

${ }^{239}$ Ibid., para. 68.

${ }^{240}$ Ibid., para. 70. It might be interesting to note that the OLG Karlsruhe for instance relied on the reports of the Committee for the Prevention of Torture of the Council of Europe in order to determine the conditions of arrest and detention in the country seeking extradition and that - since these reports stated that the conditions of the prisons in this country differed with regards to human rights protection - it then allowed the extradition only under the terms that the competent authority expressly agreed in an internationally binding way to detain the extradited person in a facility in line with the ECHR; OLG Karlsruhe, in: BeckRS 2014, No. 11797.
} 
the past. ${ }^{241}$ Concrete evidence is only dispensable if there is 'a constant practice of gross and well-known violations of human rights in the respective state on many occasions'. 242

\subsubsection{Constitutional Rights Regarding Other Aspects of EU Criminal Law}

The principle of mutual recognition has been and still is one of the most controversial issues, passionately criticised by many German authors. But of course, other matters are debated as well with regard to EU criminal law and the constitutional rights in the Basic Law. The general relationship of national constitutional rights and EU law and the respective decisions of the BVerfG have been dealt with above in Sect. 1.2.1. It should, however, be pointed out that in the view of many commentators, criminal law is a specific field that particularly affects fundamental rights and therefore demands 'a different treatment', i.e. special protection against 'encroachments' from the EU. This has different implications. For instance, the 'democratic question', to which the BVerfG turned in the light of the right to vote set out in Art. $38 \mathrm{GG}^{243}$ was also debated with regards to criminal law as an essential part of the principle of nullum crimen, nulla poena sine lege in Art. 103(2) GG. Some authors argue that the EU not only lacks the competence to enact criminal laws but also the demos to do so in a proper, democratic way. The basic rights of the accused give cause for earnest concerns as well when it comes to EU law and the 'Europeanisation' of national substantive or procedural criminal law. This has led to the rather sceptical attitude of many German scholars towards an EU criminal law. Various proposals have been published, of which a prominent one is the 'Alternativentwurf' by Schünemann et al. More recently, the European Criminal Policy Initiative published two manifestos, the first dealing with substantive criminal law and the second with criminal procedural law, ${ }^{244}$ that highlight the need for a consistent European criminal policy, including the proper protection of the rights of the accused. The multi-level system of human rights protection in the German Basic Law, the ECHR and the Charter of Fundamental Rights of the EU, and the relationship of the respective courts enforcing these rights is another matter which has given cause for critical statements, as it is feared that the standard of the constitutional rights protection of the German Basic Law which the BVerfG has established might be diminished. Space constraints do not allow a further consideration of these or other aspects of EU criminal law.

\footnotetext{
${ }^{241}$ BVerfG, case 2 BvR 2735/14, European Arrest Warrant II, order of 15 December 2015, para. 71.

242 Ibid., para. 71 .

${ }^{243}$ Cf. Sect. 1.3.3.

${ }^{244}$ http://www.crimpol.eu/.
} 


\subsection{The EU Data Retention Directive}

2.4.1 In Germany, the implementation of the Data Retention Directive ${ }^{245}$ raised deep concerns in the general public and led to severe conflicts among political parties. In order to explain the agitation, it may be helpful to recall the salience that data protection has had in Germany since the 1980s. When in 1983 the Bundestag unanimously passed a census law that included a number of questions relating to the private circumstances of the inhabitants, a broad protest movement emerged. Demonstrations were organised nationwide. Militant groups called for a boycott of the census and gave instructions how to do this. Behind the concerns was the fear that the census might open the door to a revival of authoritarianism in Germany. In December 1983, the BVerfG declared the census law unconstitutional. ${ }^{246}$ The judgment was based on Art. 2(1), the right to free development of personality. The BVerfG found that free development of personality would be seriously endangered if the state had the power to collect and use personal data without the individual knowing what the state knows about him.

To be sure, data protection had been recognised before the Census judgment as part of the protection of privacy, also derived from Art. 2(1) in connection with Art. $1(1)$ by way of interpretation. However, the Court found the existing protection insufficient in view of the new technique of electronic data processing, which allowed for the storage, use, synchronisation, transmittal and combination of large amounts of data within seconds. It thus became possible to produce a complete profile of a person. The distinction between harmless data that deserved no protection and sensitive data that had to be protected thereby lost its justification. The Court therefore dissociated data protection from privacy and derived an independent right to informational self-determination from Art. 2(1) in connection with Art. 1(1). Germany thus became a pioneer in data protection. The judgment had enormous consequences in many fields of the law. Dozens of laws had to be amended in order to bring them in line with the requirements of Art. 2(1).

The judgment gained particular importance when, following the seminal changes of 1989/90 and especially after 9/11, a number of laws against organised criminality and terrorism were passed. Between 1999 and 2014, the BVerfG reviewed eleven

\footnotetext{
${ }^{245}$ Directive 2006/24/EC of the European Parliament and of the Council of 15 March 2006 on the retention of data generated or processed in connection with the provision of publicly available electronic communications services or of public communications networks and amending Directive 2002/58/EC, [2006] OJ L 105/54.

${ }^{246}$ BVerfG, case 1 BvR 209/83 et al., Census, judgment of 15 Dec. 1983, BVerfGE 65, 1.
} 
anti-terrorism laws or laws that had been amended in connection with the so-called fight against terrorism. ${ }^{247}$ Ten of these laws created or enlarged the surveillance power of public prosecution, police, secret and other services or obligated private telecommunication enterprises to store and transmit personal data. Eight of these ten laws were declared unconstitutional, one was declared constitutional if interpreted and applied in conformity with the Basic Law, and one was found unobjectionable. Most of the laws violated Art. 2(1) (informational self-determination) in connection with Art. 1(1) (dignity); some violated the more specific guarantees of Art. 10(1) (secrecy of postal and telecommunication services) and Art. 13 (inviolability of the home), and some also violated Art. 19(4) (access to courts). ${ }^{248}$ In

${ }^{247}$ The cases are BVerfG, case 1 BvR 2226/94 et al., Telecommunications Surveillance, judgment of 14 July 1999, BVerfGE 100,313 , concerning a law that enlarged the surveillance powers of the Bundesnachrichtendienst; BVerfG, case 1 BvR 2378/98 et al., Eavesdropping (Großer Lauschangriff), judgment of 3 Mar. 2004, BVerfGE 109, 279, concerning an amendment to Art. 13, which was found compatible with Art. 79 (3), and an amendment to the statute of criminal procedure which allowed the acoustic surveillance of phones in order to fight organised criminality; BVerfG, case 2 BvR 581/01, Global Positioning System, judgment of 12 Apr. 2005, BVerfGE 112, 304, concerning a law against organised criminality that allowed the public prosecution to perform surveillance by means of GPS; BVerfG, case 1 BvR 518/02, Dragnet Investigation II, order of 4 Apr. 2006, BVerfGE 115, 320 concerning a North Rhine-Westphalian law that allowed profiling; BVerfG, case 1 BvR 1550/03, Account Master Data, order of 12 June 2007, BVerfGE 118, 168., concerning a law that allowed automatic search of banking accounts; BVerfG, case 1 BvR 370/07 et al., Online Searches, judgment of 10 Oct 2007, BVerfGE 120, 274, concerning a North Rhine-Westphalian law that allowed online search (in this case the Court developed the right to integrity and confidentiality of communication systems); BVerfG, case 1 BvR 256/08 et al., Data Retention, judgment of 2 Mar. 2010, BVerfGE 125, 260, concerning the implementation of Directive 2006/24/EC on Data Retention; BVerfG, case 2 BvR 236/08 et al., Law on the Revision of Telecommunications Monitoring (TKÜ-Neuregelung), order of 12 Oct. 2011, BVerfGE 129, 208, concerning a law that allowed the search and taping of telecommunications; BVerfG, case 1 BvR 1299/05, Assignment of Dynamic IP Addresses, order of 24 Jan. 2012, BVerfGE 130, 151, concerning a law that created a duty of private enterprises to retain certain telecommunication data; BVerfG, case $1 \mathrm{BvR}$ 1215/07 Law on the Establishment of an Anti-Terrorism Databank, judgment of 24 Apr. 2013, BVerfGE 133, 273, concerning a law that established an anti-terrorism databank. See in addition BVerfG, case 1 BvR 966/09 and 1140/09, Federal Office of Criminal Investigation (Bundeskriminalamt), judgment of 20 April 2016.

${ }^{248}$ The relevant articles read:

'Art. 1(1) Human dignity shall be inviolable. To respect and protect it shall be the duty of all state authority.

Art. 2(1) Every person shall have the right to free development of his personality insofar as he does not violate the rights of others or offend against the constitutional order or the moral law.'

Art. 10(1) The privacy of correspondence, posts and telecommunications shall be inviolable.

(2) Restrictions may be ordered only pursuant to a law. If the restriction serves to protect the free democratic basic order or the existence or security of the Federation or of a Land, the law may provide that the person affected shall not be informed of the restriction and the recourse to the courts shall be replaced by a review of the case by agencies and auxiliary agencies appointed by the legislature.

Art. 13(1) The home is inviolable.

(2) Searches may be authorised only by a judge or, when time is of the essence, by other authorities designated by the laws, and may be carried out only in the manner therein prescribed. 
almost all cases the Court found that the laws, in limiting these rights, had not stricken a proper balance between the fundamental rights of the individuals and the legitimate security interest of the state (proportionality in the narrower sense). In the judgment on online search, the BVerfG, once again in reaction to scientific and technological change, found it necessary to further develop the right to informational self-determination and derived from Art. 2(1) in connection with Art. 1(1) a constitutional guarantee of integrity and confidentiality of electronic communication systems. ${ }^{249}$

It does not therefore come as a surprise that many citizens challenged the law that was passed in order to implement EU Directive 2006/24. The BVerfG saw no need to refer the question whether the directive was valid under European law to the CJEU. The Court declared that, on the one hand, the Directive was extremely far-reaching, but found, on the other hand, that a number of particularly sensitive questions, such as the conditions of use, transfer and protection of the data retained, was left to the Member States and gave the national legislature ample discretion. In the Court's view, the Directive could be implemented in a constitutional way,

(3) If particular facts justify the suspicion that any person has committed an especially serious crime specifically defined by a law, technical means of acoustical surveillance of any home in which the suspect is supposedly staying may be employed pursuant to judicial order for the purpose of prosecuting the offence, provided that alternative methods of investigating the matter would be disproportionately difficult or unproductive. The authorisation shall be for a limited time. The order shall be issued by panel composed of three judges. When time is of essence, it may also be issued by a single judge.

(4) To avert acute dangers to public safety, especially dangers to life or to the public, technical means of surveillance of the home may be employed only pursuant to judicial order. When time is of the essence, such measures may also be ordered by other authorities designated by a law; a judicial decision shall subsequently be obtained without delay.

(5) If technical means are contemplated solely for the protection of persons officially deployed in a home, the measure may be ordered by an authority designated by a law. The information thereby obtained may be otherwise used only for purposes of criminal prosecution or to avert danger and only if the legality of the measure has been previously determined by a judge: when time is of the essence, a judicial decision shall subsequently be obtained without delay.

(6) The Federal Government shall report to the Bundestag annually as to the employment of technical means pursuant to paragraph (3) and, within the jurisdiction of the Federation, pursuant to paragraph (4) and, insofar as judicial approval is required, pursuant to paragraph (5) of this Article. A panel elected by the Bundestag shall exercise parliamentary oversight on the basis of this report. A comparable parliamentary oversight shall be afforded by the Länder.

(7) Interferences and restrictions shall otherwise only be permissible to avert a danger to the public or to the life of an individual, or, pursuant to a law, to confront an acute danger to public safety and order, in particular to relieve a housing shortage, to combat the danger of an epidemic, or to protect young persons at risk.

Article 19(4) Should any person's rights be violated by public authority, he may have recourse to the courts. If no other jurisdiction has been established, recourse shall be to the ordinary courts. The second sentence of paragraph (2) of Art. 10 shall not be affected by this paragraph.'

${ }^{249}$ BVerfG, case 1 BvR 370/07 et al., Online Searches, judgment of 10 Oct 2007, BVerfGE 120, 274. 
regardless of the primacy of EU law. ${ }^{250}$ Thus, the BVerfG could confine itself to a review of the German implementation of the Directive, which it found to be in violation of Art. 10(1) (secrecy of telecommunications) because it did not strike a proper balance between the legitimate security interest of the state and the individual freedom guaranteed in Art. 10(1).

In spite of the annulment of the Directive by the CJEU, ${ }^{251}$ a new law on data retention is being prepared. A compromise between the Minister of the Interior, who found such a law indispensable and the Minister of Justice, who found it unnecessary and constitutionally dubious, was recently reached.

\subsection{Unpublished or Secret Legislation}

2.5.1 There is not the slightest doubt that laws have to be published in order to take legal force.

The Basic Law distinguishes between the passing of a law (Zustandekommen), Art. 78, and the certification (Ausfertigung), promulgation (Verkündung) and entry into force (Inkrafttreten), Art. 82, of a law. Here the promulgation is of interest. Promulgation means the publication of the text of the law. Publication takes place at the very moment when the law gazette is distributed. ${ }^{252}$ Only upon promulgation is the legislative process completed. ${ }^{253}$ Promulgation is not a mere addition to the legislative process, but 'an integral part of the act of law-making'. ${ }^{254}$ Should a text claim to be law without having been promulgated, the BVerfG would not declare it unconstitutional, but a legal nullity. Promulgation is regarded as a requirement of the rule of law. It has the function of enabling the public to take notice of law. ${ }^{255} \mathrm{~A}$ distinction between an invalid law and a law that is inapplicable to individuals as made in the Heinrich case of the CJEU is not recognised in German constitutional law.

\footnotetext{
${ }^{250}$ BVerfG, case 1 BvR 256/08 et al., Data Retention, judgment of 2 Mar. 2010, BVerfGE 125, 260.

251 Joined cases C-293/12 and C-594/12 Digital Rights Ireland and Seitlinger and Others [2014] ECLI:EU:C:2014:238.

252 BVerfG, case 2 BvR 457/78, Legal Assistance Treaty, order of 22 Mar. 1983, BVerfGE 63, 343, 353; BVerfG, case 2 BvL 2/83, Income Tax Law, order of 14 May 1986, BVerfGE 72, 200, 241.

253 BVerfG, case 1 BvL 19/75 et al., Contergan, judgment of 8 July 1976, BVerfGE 42, 263, 283.

${ }^{254}$ BVerfG, case 2 BvL 38/56, Tax Reform of Rheinland-Palatinate, order of 19 March 1958, BVerfGE 7, 330, 337.

${ }^{255}$ BVerfG, case 2 BvL 25/81, Federal Building Act (Verfassungsmäßigkeit des Bundesbaugesetzes $\S 12$ S. 3), judgment of 22 Nov. 1983, BVerfGE 65, 283, 291.
} 


\subsection{Rights and General Principles of Law in the Context of Market Regulation: Property Rights, Legal Certainty, Non-retroactivity and Proportionality}

2.6.1 The German Bill of Rights has once been amended because of a judgment of the CJEU. The Court found that Art. 12a(4) sentence 2, according to which women were barred from rendering services in the army involving the use of arms, was incompatible with EU law. ${ }^{256}$ The amendment transformed the total prohibition into a prohibition of a duty to render armed services. But as far as I can see there are no cases in which the BVerfG has lowered the standard of fundamental rights protection in order to make its jurisprudence compatible with CJEU standards. ${ }^{257}$ It seems, however, that conflicts between the European and the German standard are becoming more likely. The well-known Solange II formula is still valid; this and further explanations are provided in Sect. 2.8.4.

As later judgments have confirmed, there has been no Solange III in which the BVerfG would have given up the power to deny European law or acts of application of European law applicability in Germany if they fall short of the German standard. ${ }^{258}$

The area where conflicts might arise is growing. In particular, the CJEU and the BVerfG differ in their interpretation of Arts. 51 to 53 of the European Charter. This will be discussed in more detail under Sect. 2.11.1.

\subsection{The ESM Treaty, Austerity Programmes and the Democratic, Rule-of-Law-Based State}

2.7.1 The Treaty Establishing the European Stability Mechanism (ESM Treaty) was challenged in the BVerfG by several individual complaints (of which one was signed by 11,717 complainants). The targets of the complaints were the German ratification law concerning the amendment of Art. 136 TFEU; the German law regarding the establishment of the ESM; the German law regulating the financial contribution of Germany to the ESM; and the German law on stability, coordination

\footnotetext{
${ }^{256}$ Case C-285/98 Kreil [2000] ECR I-00069.

${ }^{257}$ The Banana market case does not contradict this statement. It is true that the Frankfurt Administrative Court - which referred the case to the BVerfG was of the opinion that the European regulation violated - among others - Art. 14 GG (freedom of property) and Art. 12 GG (freedom of occupation). However, the BVerfG decided the case on purely formal grounds: the administrative court had failed to demonstrate that the fundamental rights protection within the EU had fallen below the standard that is indispensable according to German constitutional law (cf. BVerfG, case 2 BvL 1/97, Banana Market, order of 7 June 2000, BVerfGE 102, 147).

${ }^{258}$ See in particular BVerfG, case 2 BvE 2/08 et al., Treaty of Lisbon, judgment of 30 June 2009, BVerfGE 123, 267, 353 et seq.
} 
and control within the Economic and Monetary Union. The complaints were combined with an application for a preliminary injunction, which would prohibit the Federal President from promulgating the laws before the BVerfG rendered its decision on the subject matter. The complaints were based on Art. 38(1) (right to vote) in combination with Art. 20(1) (democracy) and Art. 79(3) (eternity clause). Some complaints relied additionally on Art. 3(1) (equal treatment), Art. 14(1) (freedom of property) and Art. 20(4) (right to resistance). Furthermore, the parliamentary group 'Die LINKE' brought an 'Organstreit' action, ${ }^{259}$ claiming (in addition to the challenges of the said laws) that their status as Members of Parliament, guaranteed in Art. 38(1)(2), had been violated.

The BVerfG rendered two judgments, one on 12 September 2012, regarding the application for a preliminary injunction, ${ }^{260}$ and one on 18 March $182014^{261}$ on the main issue.

The BVerfG proceeds on an application for a preliminary injunction only if the main proceedings are admissible (zulässig) and not evidently unfounded. If these legal requirements are met, the application is decided on factual grounds, the question being which potential harm to fundamental rights or other constitutionally protected goods would be greater: the harm if the injunction were granted but it was later determined in the main proceedings that the law at stake was constitutional, or the harm if the injunction were refused and later the law was found unconstitutional. Since this decision requires predictions, the assessment of the Government is usually given strong weight.

The decision in the injunction proceedings basically follows this pattern. The BVerfG declared the individual complaints admissible insofar as they were based on Art. 38(1) in combination with Art. 20(1) and Art. 79(3). The Organstreit proceedings were found admissible with the exception of one of the claims. However, the judgment is unusual insofar as the question whether the main proceedings have a chance of success is treated in great length (almost 50 pages in the official publication) although the Court calls it a summary review. This was, of course, due to the immense urgency of the issue. The Court reached the conclusion that most of the claims had no chance of success. Insofar as they might have a chance of success, the Court made the ratification and promulgation of the laws connected with the ESM dependent on a binding clarification in international law that the financial obligations of the Federal Republic would not exceed the limit set in Annex II of the Treaty, that no additional obligation could be requested without the consent of Germany and furthermore that the provisions of the Treaty would not

\footnotetext{
259 The 'Organstreit' is regulated in Art. 93 (1) GG: 'The Federal Constitutional Court shall rule 1. on the interpretation of this Basic Law in the event of disputes concerning the extent of the rights and duties of a supreme federal body or of other parties vested with rights of their own by this Basic Law or by the rules of procedure of a supreme federal body'.

${ }^{260}$ BVerfG, case 2 BvR 1390/12 et al., ESM \& TSCG - summary review, judgment of 12 Sept. 2012, BVerfGE 132, 195.

${ }^{261}$ BVerfG, case 2 BvR 1390/12 et al., ESM \& TSCG, final decision, judgment of 18 Mar. 2014, BVerfGE 135, 317.
} 
prevent the full information of the Bundestag. Given this result of the summary review, an assessment of the consequences of either granting or refusing the injunction was no longer necessary.

The opinion referred to the previous judgments of the BVerfG in European matters. As early as 1993, the Court had ruled in its Maastricht decision that individual complaints against amendments of the Treaties of Rome may be based on an alleged violation of the right to vote in Art. 38(1). ${ }^{262}$ According to the opinion, the right to vote not only guarantees participation in elections, but also that the elected body, the Parliament, has sufficient power to translate the popular will into political measures. A transfer of powers to the EU that would deprive the Bundestag of substantive legislative powers would violate the right to vote. The measures to cope with the financial crisis gave the Court an opportunity to concretise this ruling with regard to the budgetary powers of the Bundestag. ${ }^{263}$

The Court regarded the budget as a central element of democratic will formation. It is fundamental for the self-government of the people. The budget is the place where conceptual political decisions find expression. Hence, Art. 38(1) prevents the Bundestag from giving up its responsibility for the budget (Haushaltsverantwortung) in a way that it or a future Parliament would no longer be able to exercise budgetary power in a responsible way. However, membership in a supranational organisation is not per se at odds with this responsibility. Even if treaty obligations are very high, they do not violate the Bundestag 's budgetary power, provided that the Bundestag remains the place where any decision regarding a transfer of resources to a supranational entity like the EU is taken. Similarly, the duty to follow a certain budgetary or fiscal policy does not necessarily violate the principle of democracy if it is self-imposed. The decision of the Bundestag must be free from external determination. Budgetary responsibility may not be transferred to other actors by way of giving these actors discretion as to what is required from the Federal Republic. Blanket empowerments of international organisations are prohibited. The financial burden for the Federal Republic has to be calculable.

The Court had earlier found the rescue measures for Greece in stark tension with these principles. ${ }^{264}$ It nevertheless reached the result that they were acceptable because the financial engagement was limited (at that time to 123 billion EUR plus a possible $20 \%$ surplus that would raise the guarantee to 147.6 billion EUR); because every single measure required the consent of the Bundestag and the conditionality of resource grants remained under its control; finally because the rescue programme was limited in time.

The tension increased immensely, however, with the establishment of the ESM. This was no longer a temporary but rather a permanent institution, and the amount

\footnotetext{
262 BVerfG, case 2 BvR 2134, 2159/92, Treaty of Maastricht, judgment of 12 Oct. 1993, BVerfGE $89,155,171$ et seq.

${ }^{263}$ BVerfG, case 2 BvR 1390/12 et al., ESM \& TSCG - summary review, judgment of 12 Sept. 2012, BVerfGE 132, 195.

${ }^{264}$ BVerfG, case 2 BvR 987/10 et al., Aid to Greece \& EFSF, final decision, judgment of 7 Sep. 2011, BVerfGE 129, 124, 180.
} 
of money to be put at the disposal of the ESM rose to around 190 billion EUR (the annual budget of the Federal Republic without the budgets of the Länder is around 300 billion EUR). Although in the view of the BVerfG the new Art. 136(3) TFEU leads to a fundamental change with regard to the Economic and Monetary Union insofar as the autonomy of the national budget is severely restricted, it does not amount to a loss of that autonomy, since it does not include a transfer of competences to the EU. In sum, the Court found that the basic principles of the Monetary Union were still preserved, to wit the prohibition of a financing of a Member State's budget by the ECB and the prohibition of a bail out. Some dangers that the ESM created for national sovereignty could be dealt with by a binding interpretation of the treaty. The suspension of the voting rights of Member States in default was not imminent if the ability of the Bundestag to provide the necessary sum was guaranteed. Ultimately, the Court overcame its concerns by mentioning that it had constantly strengthened the position of the Bundestag within the German political system.

After this decision in the injunction proceedings, it could not come as a surprise that the Court approved the constitutionality of the ESM Treaty in the main judgment. $^{265}$ The complainants had meanwhile extended their challenges to a number of subsequent German and European legal acts, among them the so-called Sixpack and the TARGET2-system. Before the final judgment was rendered, the CJEU had decided that the amendment of Art. 136 TFEU was compatible with Art. 48 TEU as well as with Art. 125 TFEU. ${ }^{266}$ The ESM Member States had issued a declaration in 2012 that satisfied the conditions of the preliminary judgment of the BVerfG. This opinion is shorter than that of 2012 (35 pages). The criteria applied are the same. The individual complaints and the claim by 'Die LINKE' were dismissed.

2.7.2 Even before the final decision in the ESM case, the BVerfG had to deal with the Outright Monetary Transactions (OMT), announced but not yet implemented by the European Central Bank (ECB). The complainants in the OMT case were largely identical to those in the ESM proceedings. Their complaints as well as the 'Organstreit' procedure brought by 'Die LINKE' were directed against the decision of the ECB of 6 September 2012, and furthermore against the failure of the Federal Republic to take action against the decision of the ECB. The 'Organstreit' aimed at obliging the German Bundestag to undertake steps toward an abrogation of the ECB's decision and towards a ban of the measures announced in that decision. Because the OMT programme had not actually been implemented, the Bundestag and the federal Government argued that the case was inadmissible. With a 6:2 decision, the BVerfG stayed the procedure and referred a number of questions concerning the compatibility of the ECB decision with Union law to the CJEU. ${ }^{267}$ It

\footnotetext{
${ }^{265}$ BVerfG, case 2 BvR 1390/12 et al., ESM \& TSCG, final decision, judgment of 18 Mar. 2014, BVerfGE 135, 317.

${ }^{266}$ Case C-370/12 Pringle [2012] ECLI:EU:C:2012:756.

${ }^{267}$ BVerfG, case 2 BvR 2728/13 et al., OMT, order of 14 Jan. 2014, BVerfGE 134, 366.
} 
was the first referral for a preliminary ruling by the BVerfG ever. The BVerfG had serious doubts as to whether the decision of the ECB was within the limits of the bank's power and stated these doubts in a 62 page opinion. The Court affirmed its position that it is prepared to deny European legal acts applicability in Germany if they are ultra vires or interfere with the identity of the Basic Law.

Meanwhile, the CJEU has responded, saying that provided that some provisos are observed, the decision of the ECB does not violate Union law. ${ }^{268}$ The BVerfG is now proceeding with the case. The oral argument took place in February 2016.

Altogether there are now eight judgments from Karlsruhe concerning measures taken in order to cope with the financial crises:

- BVerfGE 125, 385 (2010) - Aid to Greece, injunction

- BVerfGE 129, 124 (2011) - Aid to Greece \& EFSF, final decision

- BVerfGE 130, 318 (2012) - EFSF - Special Parliamentary Committee

- BVerfGE 131, 152 (2012) - ESM \& Euro Plus Pact - Information of the Bundestag

- BVerfGE 132, 195 (2012) - ESM \& TSCG - summary review

- BVerfGE 132, 287 (2012) - Ratification of amendment to Art.136 TFEU, injunction

- BVerfGE 134, 366 (2014) - OMT, referral to the CJEU

- BVerfGE 135, 317 (2014) - ESM \& TSCG, final decision.

\subsection{Judicial Review of EU Measures: Access to Justice and the Standard of Review}

2.8.1 (a) There is no information available on the number of applicants that have requested a preliminary ruling with regard to the validity of an EU measure in German courts.

(b) From 2006 to 2014, German courts sent 672 preliminary ruling requests to the CJEU, the highest number (97) in 2013, the lowest (59) in 2007 and 2009. No information is available as to the European measures contested.

(c) There are no figures available with regard to preliminary ruling references from German courts that have led to a partial or full annulment of the relevant EU measure.

2.8.2 In general, the CJEU submits national law to a rather strict standard of proportionality, whereas it applies a lenient standard to Union law. Consequently, the standard of judicial review of the European Court vis-à-vis Union law is lower than the standard of national constitutional courts or supreme courts vis-à-vis national law. In addition, there are differences regarding the fundamental rights or

${ }^{268}$ Case C-62/14 Gauweiler and Others [2015] ECLI:EU:C:2015:400. 
principles involved. The CJEU protects the four economic freedoms and their concretisation more strictly than the Member States' courts usually protect economic rights. As a general rule, one can say that in Germany, economic rights like freedom of property and freedom of profession (which include most of the four economic freedoms) are the weakest rights unless they touch upon the preconditions of the free development of personality. This follows already from the unique formulation of Art. 14 (freedom of property). According to Sect. 1, not only the limits but also the content of the right may be determined by law. Section 2 reads: 'Property entails obligations. Its use shall also serve the public good.' Regarding Art. 12 (freedom of profession), it follows from the difference between the individual choice of a profession, which is protected strongly, and the exercise of a profession, which is subject to broad regulation. ${ }^{269}$

2.8.3 The BVerfG clearly takes a rigorous approach when reviewing legislation as well as regulations and administrative acts. So do the administrative courts vis-à-vis administrative acts. Perhaps the most important effect of the Court's jurisprudence and popular support is that the requirements of the Basic Law are taken into account relatively early and in a relatively neutral way in the process of legislation. In particular, if draft laws originate in the executive (which is true for the vast majority of drafts), the Constitution and the jurisprudence of the Constitutional Court are constantly present. Each draft is submitted to a constitutionality check by the Ministry of Justice and/or the Ministry of the Interior. Also the constitutionality of international agreements is reviewed early in the Ministry of Foreign Affairs in order to avoid a defeat in the BVerfG when it comes to ratification in the German Parliament.

There are three proceedings in which a legal norm can be reviewed as to its constitutionality: abstract norm control (initiated by the Federal Government, the Governments of the Länder and a certain portion of the Members of Parliament; for a long time this was one-third of the Members of Parliament, but as of recently, one-fourth); concrete norm control (referral by ordinary courts for a preliminary ruling) and individual complaints. The possibility for individuals to directly challenge a law is restricted; usually it is an incidental review, enabled by the requirement that a fundamental right may only be limited on the basis of a valid law. Around $96.5 \%$ of all proceedings are constitutional complaints, of which some $2 \%$ are successful. The next most frequent proceeding is concrete norm control, representing about 35 cases per annum, whereas cases of abstract norm control are very rare (an average of 2.5 per annum).

The total number of laws that have been declared unconstitutional is: 484 federal laws, 213 state (Länder) laws. In the last five years, the figures are 39 federal laws and 35 state laws, which is an average of six federal laws and seven state laws per year.

${ }^{269}$ See, e.g., BVerfG, case 1 BvR 532/77 et al., Co-determination, judgment of 1 March 1979, BVerfGE 50, 290. 
Among the norms that have been declared unconstitutional, a few have failed because the legislative procedure did not meet the requirements of the Basic Law (e.g. the rights of the Bundesrat were disregarded). A little higher is the amount of laws that have failed because Parliament lacked the competence for the subject matter. The majority have failed because they violated fundamental rights. The vast majority of these laws have not met the requirements of the principle of proportionality. The majority among these failed at the last stage of the proportionality test (proportionality in the narrower sense, balancing).

In order to assess the impact of judicial review fully, it should be borne in mind that the BVerfG not only confirms or annuls existing laws, but also obliges the legislature to legislate if protection (or better protection) of a fundamental right is required by the Constitution. This requirement need not be explicitly provided for in the text. The BVerfG recognises an obligation of the state to protect fundamental rights from menaces emanating not from the state itself, but from private or social actors (the so-called duty to protect, Schutzpflicht).

2.8.4 The BVerfG not only claims the power to review national laws that implement Union law, it also exercises this power. The most recent examples are the decisions on the European Arrest Warrant and on the data retention law. ${ }^{270}$ In both cases, the Court refrained from reviewing the European framework decision and the European directive respectively, but declared the German laws that implemented them unconstitutional because - within the German Parliament's area of discretion - the Bundestag did not provide sufficient protection of fundamental rights guaranteed in the Basic Law. However, there seems to be a different opinion regarding the delimitation of the discretion that a directive or framework decision leaves. The CJEU tends to define it more narrowly than the BVerfG.

However, the BVerfG declares referrals of national laws that implement Union law inadmissible if the ordinary court has not sufficiently clarified whether the national laws only implement Union law or act within the area of discretion. ${ }^{271}$ Still, in the Data Retention case the Court found an individual complaint against a national law that implemented mandatory Union law to be admissible. The complainant had argued that the EU lacked legislative power to regulate the subject matter and in addition violated EU Charter rights. In the Pringle case, the CJEU had previously rejected a claim by Ireland that the EU lacked legislative competence in this subject matter. ${ }^{272}$ It had, however, left open the question of compatibility with Charter rights. The BVerfG considered the individual complaint admissible, although it was based on Union law, because the complainants pursued the aim of obtaining a referral by the BVerfG to the CJEU in the expectation that the CJEU

\footnotetext{
${ }^{270}$ BVerfG, case 2 BvR 2236/04, European Arrest Warrant I, judgment of 18 July 2005, BVerfGE 113, 273; BVerfG, case 1 BvR 256/08 et al., Data Retention, judgment of 2 Mar. 2010, BVerfGE 125, 260; BVerfG, case 2 BvR 2735/14, European Arrest Warrant II, order of 15 December 2015.

${ }^{271}$ BVerfG, case 1 BvL 3/08, Investment Allowance Act, order of 4 Oct. 2011, BVerfGE 129, 186.

${ }^{272}$ Case C-370/12 Pringle, n. 266.
} 
would annul the Directive on Charter grounds and so pave the way for the BVerfG to review the German law. ${ }^{273}$ The BVerfG found, however, that a preliminary ruling by the CJEU was not necessary since the European directive left sufficient room for national legislation and that the challenged norms were not determined by Union law. ${ }^{274}$

Solange II is not relevant in this context. It applies to Union law and its compatibility with the Basic Law. To this extent Solange II is still valid law:

As long as the European Communities, in particular European Court case law, generally ensure effective protection of fundamental rights against the sovereign powers of the Communities, which is to be regarded as substantially similar to the protection of fundamental rights required unconditionally by the Constitution, and insofar as they generally safeguard the essential content of fundamental rights, the BVerfG will no longer exercise its jurisdiction to decide on the applicability of secondary Community legislation cited as the legal basis for any acts of German courts or authorities within the sovereign jurisdiction of the Federal Republic of Germany, and it will no longer review such legislation by the standard of fundamental rights contained in the Basic Law. ${ }^{275}$

The BVerfG rejects individual complaints against Union law and referrals of Union law to Karlsruhe unless they specify that the European standard of fundamental rights protection is no longer equivalent to the German standard.

Some authors understand the judgment of the BVerfG in European Arrest Warrant II as a Solange III. In this decision the BVerfG reiterated its jurisprudence that there are insurmountable limits to the applicability of EU law in Germany, which follow from the identity of the German Constitution as laid down in Art. 79(3). Among them is the guarantee of human dignity. As a consequence, the BVerfG considers an individual complaint to be admissible if it claims a violation of Art. 1(1) of the Basic Law. In such a case the Court will review the act that is challenged 'irrespectively of its jurisprudence as to the inadmissibility of individual complaints and referrals which claim a violation of fundamental rights in the Basic Law by secondary Union law'. ${ }^{276}$ Here the Court guarantees indispensable fundamental rights protection, unrestricted in the specific case, by way of identity control. ${ }^{277}$ However, the Court avoided a conflict with EU law by finding no significant difference between the requirements of Art. 1(1) of the Basic Law and EU law in the case at hand.

\subsubsection{In its Solange II judgment, the BVerfG admitted that}

compared with the standard of fundamental rights under the Basic Law it may be that the guarantees for the protection of such rights established thus far by the decisions of the European Court, since they have naturally been developed case by case, still contain gaps

\footnotetext{
273 BVerfG, case 1 BvR 256/08 et al., Data Retention, judgment of 2 Mar. 2010, BVerfGE 125, 260,306 et seq.

274 Ibid., pp. 308 et seq.

275 BVerfG, case 2 BvR 197/83, Solange II, order of 22 Oct. 1986, BVerfGE 73, 339, LS 2.

276 BVerfG, case 2 BvR 2735/14, European Arrest Warrant II, judgment of 15 December 2015, para. 34.

277 Ibid., para. 49.
} 
... . What is decisive, nevertheless, is the attitude of principle which the Court maintains at this stage towards the Community's obligations in respect of fundamental rights. ${ }^{278}$

This statement is followed by the well-known formula that the European Court's case law has generally to ensure effective protection of fundamental rights, which is substantially similar to the protection of fundamental rights in the Basic Law and in so far as they generally safeguard the essential content of the fundamental rights. This shows that certain differences and gaps are accepted as inevitable consequences of the independence of the two courts in the different contexts - state here, international community there - in which they operate.

2.8.6 The issue of equal treatment of individuals falling within the scope of EU law and domestic law has not arisen.

\subsection{Other Constitutional Rights and Principles}

2.9.1 Space does not allow for consideration of further issues.

\subsection{Common Constitutional Traditions}

2.10.1 A book titled 'An Inquiry into the Existence of Global Values: Through the Lens of Comparative Constitutional Law' was recently published. ${ }^{279}$ The editors developed a list of candidates for common values and asked the national rapporteurs from sixteen states (including this author as rapporteur for Germany) to report on the recognition and prioritisation of these values in their various countries. As it turned out, there is a significant amount of congruence throughout the constitutional and political systems.

This is even more true for Europe. The European Convention on Human Rights has been adopted by 47 states, the Charter of Fundamental Rights of the European Union by 28 states. If one compares the bills of rights of the various states, one finds similar rights. In states with thin or rudimentary bills of rights, the gaps are filled by referring to the European rights. On first view, a comparison between the EU Charter and the German Basic Law shows that the Charter contains about twice as many fundamental rights as the German Basic Law. But a closer look reveals that a number of rights that appear separately in the Charter are united in one article in the Basic Law (Art. 5, e.g., contains five rights: freedom of expression, freedom of information, freedom of the media, freedom of art and freedom of science).

\footnotetext{
${ }^{278}$ BVerfG, case 2 BvR 197/83, Solange II, order of 22 Oct. 1986, BVerfGE 73, 339, 383. Quotation in Sect. 2.6.1.

279 Davis et al. 2015.
} 
A number of rights that are specified in the Charter are derived from enumerated rights by way of interpretation in the Member States. It is not easy to find a right in the Charter that is not recognised in Germany. What does not exist in the German Constitution is an individual right to good administration (Art. $41 \mathrm{EU}$ Charter) and a number of the provisions in title IV of the Charter.

The congruence decreases, however, when it comes to the rules on limitation of fundamental rights and even more so to interpretation and enforcement. Only if these elements are taken into account does a realistic picture as to what is common and what is not develop. And here even the differences within Europe are not small, as can be seen from the jurisprudence of the European Court of Human Rights. A good example is the ubiquitous conflict between freedom of expression/freedom of the media and privacy/personal honour. When it comes to striking a balance between these commonly accepted values, the results differ from country to country. Still, it is not in vain to ask where common values are constitutionally recognised in order to have a starting point for the discourse. The fact that, unlike other continents, Europe has developed mechanisms to guarantee a minimum standard in all countries and, to a certain extent, to harmonise different standards prepares the ground for approximation.

2.10.2 Article 4(2) TEU obliges the European Union to respect the national identities of the Member States inherent in their fundamental political and constitutional structures. This includes the various traditions and standards of fundamental rights protection. Charter rights that result from the constitutional traditions common to the Member States shall be interpreted in harmony with those traditions (Art. 52(4) Charter). Already before the adoption of the Charter, the CJEU derived unwritten fundamental rights from the ECHR and the 'common national traditions' of the Member States. The latter was often lip service. There are cases where a common standard was alleged without evidence and was even asserted when in fact it was lacking. ${ }^{280}$ The Charter which has been adopted by all Member States makes this superfluous. Now it seems more important to stress the legitimate remaining differences and to oblige the EU to respect them in the spirit of Art. 4(2) TEU and Art. 52(4) Charter. The point of departure could be the exceptions from requirements of Union law that the Treaties allow on grounds of public policy, public security, public health, etc. These public interests of the Member States find their highest expression in the national bills of rights.

It would be recommendable for the national courts, when referring questions to the CJEU, to make it clear where longstanding traditions or deep convictions form a barrier for abolishing national institutions or harmonising the law of the EU. The BVerfG was frequently criticised when, in the judgments on the Maastricht and Lisbon treaties, it explained the identity of the German Constitutional order. Yet this is precisely the information that the CJEU needs if it wants to take Art. 4(2) TEU seriously.

${ }^{280}$ A good example is Case C-144/04 Mangold [2005] ECR I-09981. 


\subsection{Article 53 of the Charter and the Issue of Stricter Constitutional Standards}

2.11.1 There is an extensive discussion about the exact meaning of Art. 53 of the Charter. ${ }^{281}$ Article 53 adopts Art. 53 of the European Convention. Both pursue the same goal: European fundamental rights protection shall not lessen the standard of fundamental rights protection granted by the national constitutions. However, the two rules differ in one important aspect. In the EU, the safeguard against an interpretation of Charter rights, which restricts or negatively affects the fundamental rights of the national constitutions, is valid 'in their respective fields of application'. The interpretation of Charter rights may not lower the national standard of fundamental rights protection in the areas where they apply. Where they do not apply, the prohibition is not valid. There, Charter rights may fall short of the national standard.

This diversion reflects the difference in function and application of the ECHR and the EU Charter. The European Convention applies comprehensively. All acts of national public authority have to comply with the Convention. Yet the Convention confines itself to setting a minimum standard that has to be respected by all 47 member states. Beyond this minimum standard, it leaves the plurality of national standards unaffected. The Convention rights become relevant only where a national bill of rights or its application falls short of the European minimum standard. For member states with a high standard of fundamental rights protection, this will not often be the case.

To the contrary, the European Charter does not content itself with setting a minimum standard. It contains a fully developed catalogue of fundamental rights, even larger in number than the catalogues of many Member States. Wherever Charter rights apply they shall get full credit. Yet they do not apply comprehensively to all legal acts of national public authority. This is a consequence of the fact that the EU is a federal entity and, as in every federal entity, the demarcation of competences is of pivotal importance.

The demarcation is drawn by Art. 51 EU Charter. According to this provision, the Charter applies without exception to all institutions of the EU, whereas it applies to the Member States 'only when they are implementing Union law'. Consequently, in dealing with the European Convention, the question is whether the national standard of protection falls short of the European standard. In dealing with the European Charter this question is likewise important, but the delimitation of applicability of the Charter shifts the accent from the standard of protection to the field of application. The question where Charter rights apply and where the fundamental rights guaranteed in the national constitutions apply does not play a role under the European Convention.

The difference has an impact on the role of the two European courts. The European Court of Human Rights is an international court. It can only declare that a

\footnotetext{
${ }^{281}$ For some recent examples, see Britz 2015; Franzius 2015a, b; Masing 2015; Thym 2015; see also Nusser 2011.
} 
legal act of a member state violates the Convention, but it cannot annul or reverse the act at stake. It is not an appellate court. The member states are under an obligation to eliminate the violation, but whether and how they do so depends on their domestic law. Likewise, the ECtHR has no mandate to harmonise fundamental rights protection in Europe. The CJEU, on the contrary, may harmonise fundamental rights protection in the areas where the Charter applies. It is not an appellate court either, but national law that, in its view, contravenes European law automatically loses its applicability.

Hence, the decisive question for the EU is what are the areas in which the Charter applies and what are the areas in which the national bills of rights apply. This is controversial. The controversy goes back to differences in the relevant legal texts. Article 51 of the Charter states that Charter rights apply to the Member States 'only when implementing Union law'. Yet, according to the explanation to Art. 51, Charter rights apply to the Member States 'in the field of application of Union law'. This formula is reminiscent of the jurisprudence that the CJEU developed before the Charter entered into force. It now gives the CJEU an opportunity to continue its pre-Charter line of jurisprudence, regardless of the stricter wording of Art. 51.

This is not just a variation in language, it is also a variation in meaning. Although the Charter clearly wanted to restrict the application of Charter rights to the benefit of national rights, the explanation suggests that the difference in text does not matter. To what extent it matters can be seen in the ERT case. ${ }^{282}$ Greece had established a monopoly in public television. The prohibition of private television enterprises was based on a Greek law. Enforcing this law was not implementing Union law, but it was done in the field of application of Union law because the question whether Greece was permitted to restrict the free movement of services is a question of Union law.

The ERT example has been chosen to show that the outcome depends on which text is used as a basis for decision. A closer look shows, however, that a strict interpretation of Art. 51 would not be helpful. There are cases of implementation of national law where good reasons not to apply the national bill of rights but the Charter exist nevertheless. These are cases where the law at stake is a national law, but a national law that is determined by Union law. Under a substantive, as opposed to formal, perspective the national authorities and courts implement Union law and there is a legitimate interest in guaranteeing a uniform application of this law in all Member States, which excludes the application of domestic fundamental rights. This is widely accepted also by the national courts.

On the other hand, it is not sufficient for the application of Charter rights that the national law at stake is somehow related to Union law, as for instance the Akerberg Fransson case suggests. ${ }^{283}$ Given the degree of entanglement between European and national law, it would be all too easy to find such a connection wherever the CJEU wants. Should Akerberg Fransson set the standard for the interpretation of

\footnotetext{
${ }^{282}$ Case C-260/89 ERT [1991] ECR I-02925.

${ }^{283}$ Case C-617/10 Åkerberg Fransson [2013] ECLI:EU:C:2013:105.
} 
Art. 51, this provision would lose all its contours and render the restriction contained in it virtually obsolete, and with it Art. 53, which depends on the demarcation in Art. 51 for its effect.

This is the position of the BVerfG. According to its jurisprudence, a Member State 'implements Union law' when it applies national law only insofar as the national law is 'determined' by Union law. ${ }^{284}$ A mere relation with Union law (unionsrechtliche Bezüge) or an indirect impact (mittelbare Auswirkungen) is insufficient to supersede national fundamental rights. The BVerfG finds that this understanding is supported by Art. 51(2) of the Charter. The Court insists that this ruling does not contradict the judgment of the CJEU in the Akerberg Fransson case. The cooperative relationship between the two courts prohibits an interpretation (Lesart) of that decision according to which it would be a clear ultra vires act or would endanger the identity of the German constitutional order. 'Consequently, the decision may not be understood or applied in a way that, in order to bind the member states by the Charter rights, any connection between a [national] rule and the abstract field of application of Union law or a pure factual impact on Union law would suffice. ${ }^{285}$

This shows that a principle is necessary in order to distinguish between the implementation of national law where Charter rights must be observed and the implementation of national law where the national bills of rights apply. This criterion can only be the interest in a uniform application of Union law or Union-induced law in order to make it independent from the various national bills of rights and their interpretation by national constitutional or supreme courts. Hence, the decisive question is whether the uniform application of national implementation of law is indispensable as a guarantee for the Europe-wide effectiveness of the Union law that is implemented.

As a consequence, national fundamental rights apply wherever Union law leaves a field of discretion to the national lawmaker. The European lawmaker itself has indicated that uniformity is not regarded as necessary to this degree. This is usually the case with directives. They are binding with regard to the goal of the law, but they leave it to the national legislatures to determine the ways and means to reach the ends. The discretion of the Member States can be wider or narrower, but it cannot be totally absent, because this would mean that the EU has abused the legal instrument of a directive.

If this criterion is employed, decisions like ERT and Akerberg Fransson deserve criticism. ERT shows that a more subtle distinction is necessary than that used by

\footnotetext{
${ }^{284}$ BVerfG, case 1 BvF 1/05, Greenhouse Gas Emissions Allowance, judgment of 13 Mar. 2007, BVerfGE 118, 79, 95; BVerfG, case 1 BvR 256/08, Data Retention (Vorratsdatenspeicherung), order of 11 Mar. 2008, BVerfGE 121, 1, 15; BVerfG, case 1 BvR 256/08 et al., Data Retention, judgment of 2 Mar. 2010, BVerfGE 125, 260, 300 et seq.; BVerfG, case 1 BvR 1916/09, Extension of the Application, order of 19 July 2011, BVerfGE 129, 78, 90 et seq.; BVerfG, case 1 BvR 1215/07, Anti-Terrorism Databank, judgment of 24 Apr. 2013, BVerfGE 133, 277, 313.

${ }^{285}$ BVerfG, case 1 BvR 1215/07, Anti-Terrorism Databank, judgment of 24 Apr. 2013, BVerfGE $133,277,313$ et seq.
} 
the CJEU. On the one hand, the European legislature has not harmonised media law. Yet it prohibits monopolies, however with exceptions. If a Member State claims an exception, it applies and interprets Union law. It may be that the conditions for an exception were not given. To decide this is a matter of Union law. But within the boundaries of the exception the national legislature enjoys freedom to decide, and this means that here not Charter rights but national fundamental rights apply.

The connection between Union law and national law that the CJEU saw in Akerberg Fransson was that the Member States owe a certain portion of income tax to the EU and are therefore obliged to efficiently levy this tax. But the question whether the efficiency principle requires one or two sanctions in cases of tax evasion is not determined by Union law and is therefore open to national legislation, with the consequence that not the European Charter but the national bill of rights applies.

This case shows at the same time the danger that accompanies the jurisprudence of the CJEU. It undermines Art. 51(2) of the Charter that prohibits an extension of Union law beyond the competences conferred by the Member States and the creation of new competences. If, for example, the Charter right of data protection is at stake, this opens the doors to a lot of national competences that have not been conferred to the EU because data protection is not a limited area of the law but applies to all activities of the state. It is an all-encompassing law. If any relationship between Union law and national law were sufficient for the application of Charter rights, this would mean access to and uniformity of many legislative competencies that have not been conferred.

There are, however, some recent judgments of the CJEU that suggest the existence of an area where the Charter and the national bills of rights apply simultaneously. In the Melloni case the Court ruled: 'Article 53 of the Charter confirms that where an EU legal act calls for national implementing measures, national authorities and courts remain free to apply national standards of protection of fundamental rights, provided that the level of protection provided for by the Charter, as interpreted by the Court, and the primacy, unity and effectiveness of EU law are not thereby compromised.'286

Does this mean that areas exist where Charter rights and national constitutional rights overlap? In a strict sense this seems impossible, because in cases where the standard of fundamental rights protection differs, the question of which standard applies is inevitable. In order to avoid this, the Court has formulated a condition for the application of the national standard, namely that the primacy, unity and effectiveness of EU law are not thereby compromised. Wherever this danger appears, national fundamental rights have to give way. The overlap is thus reduced to cases where European and national rights offer the same standard of protection. In this respect it does indeed not matter which rights are applied. Where this is not the

${ }^{286}$ Case C-399/11 Melloni, n. 161, para. 60. 
case, the Charter is clearly hierarchically superior, regardless of the standard of protection.

Article 53 of the Charter has therefore a different meaning compared to Art. 53 of the European Convention. The reason for the difference lies in the fact that the Convention guarantees only a minimum standard, while the member states are free to guarantee better protection above this minimum. The Charter, on the other hand, establishes full protection in the areas in which it applies. This leaves no room for an interpretation according to which full protection would apply only to EU institutions while the Member States have to maintain but a minimum standard. The European and the national standards do not apply simultaneously, in parallel or cumulatively, rather either one or the other applies.

Thus, unlike the Convention, the Charter leaves no room for the question of which standard is higher. Article 53 does not privilege the higher standard. It only protects the national standard against diminution by EU law in areas where the national standard applies. As has been seen, this question can be very difficult to decide, in particular if a determination by EU law and discretion for national regulation are combined in one directive or framework decision. Here a particularly careful analysis is necessary, but it is an analysis of EU law. It has to be undertaken by the national authorities; however, since the area of national discretion is determined by EU law, the CJEU has the last word.

Particular difficulties arise in constellations where different fundamental rights have to be balanced against one another. Under the Convention it is difficult to comply with Art. 53 because greater protection of one right automatically means less protection for the other right. The conclusion should be that particular respect has to be paid to the result adopted by the nation states. The margin of appreciation applies here. The ECtHR should find a violation of the Convention only if the balance determined by the national court seems grossly distorted. But also the CJEU should be careful, in particular if the result would be a prioritisation of a whole group of fundamental rights over another.

\subsection{Democratic Debate on Constitutional Rights and Values}

2.12.1 I do not remember whether the adoption of the EAW Framework Decision or its implementation by Germany was preceded by an intensive public debate. The European Data Retention Directive and its implementation by Germany were the subject of a heated debate that even divided the German Government. While the Minister of the Interior insisted on implementation, the Ministry of Justice (first under a minister from the liberal FDP, then under Social Democratic ministers) refused to submit a draft because it assumed that the directive had no basis in the European treaties and implementation would be incompatible with the Basic Law. 
2.12.2 The enforcement action against Germany, in particular the amount of the fine, was used as an argument for implementation by the Ministry of the Interior, but rejected by the Ministry of Justice.

Regarding the question of sufficient space for democratic deliberation and judicial review in the Member States, it has to be noted that the duty to implement a European directive in due time should not depend on constitutional concerns in the Member States. It would be all too easy for the Member States to raise such concerns in order to escape sanctions by the EU. If the concerns have their grounds in European law, be they questions of competence or of fundamental rights, the Member States have the possibility to bring an action of annulment in the CJEU.

2.12.3 I would favour the idea that an action for annulment of a directive would suspend an enforcement mechanism such as a fine, until the CJEU has decided the matter.

\subsection{Experts' Analysis on the Protection of Constitutional Rights in EU Law}

2.13.1 The question requires a differentiated answer. The standard of protection of the four fundamental freedoms, which are all economic freedoms, freedoms of the market participants, is very high in the EU. The same is true for some other rights such as gender equality and other anti-discrimination rules. But this high level of protection has a drawback for further, non-economic fundamental rights. In a conflict between the four economic freedoms and non-economic rights, the economic rights tend to prevail in the CJEU. The conflict arises in particular when a Member State claims an exception from the free movement principle and bases this claim on national fundamental rights. The likelihood that the Member States will lose before the CJEU is higher than the likelihood that they will win. The economic freedoms have thus become what in the US would be called 'preferred freedoms' (the example being freedom of speech in the First Amendment).

2.13.2 No state that joins a supranational entity like the EU or the Council of Europe can expect to uphold its standard of fundamental rights protection completely. This would mean that one national standard would be made dominant over all other member states. There will always be gains and losses. As far as the ECHR is concerned, which confines itself to a minimum standard that all countries in spite of their various traditions are obliged to respect, the loss will be small for countries with a highly developed standard of fundamental rights protection. This is true for Germany. Not many German decisions have been found to be in violation of the Convention. Several cases in which this has happened have concerned the balancing of conflicting fundamental rights, which the ECtHR should abstain from reviewing in the light of Art. 53, unless the balance is grossly distorted (see Sect. 2.11.1). A typical conflict that occurs in almost all member states is the 
already mentioned conflict between freedom of expression/freedom of the press and personality rights/privacy. There are many ways to solve this conflict in the member states of the Council of Europe, with one jurisdiction tending more to the communicative rights, others more to personal rights. It is not the business of the ECtHR to require a uniform attitude.

This is different in an entity like the EU that develops a genuine catalogue of fundamental rights and a genuine standard of protection, but limits them to transnational relations, leaving purely national relations to the national bills of rights and the jurisprudence of the national courts. However, since not only legal acts of the Union organs are submitted to the European Charter but in an increasing number of cases also acts of the Member States, the national constitution can no longer maintain its claim to comprehensive application on the territory of the state. Again, it would be unreasonable to expect that a national standard would survive this process unaffected.

Also in the EU it is a question of gains and losses. However, for Germany with a high standard and human dignity as the highest right of an absolute character that can neither be trumped by another right nor submitted to balancing, the danger is particularly high. This is why the losses weigh heavier for Germany than for a number of other countries. Still, the degree of loss depends on whether there are changes in detail or in principle. The CJEU's practice in giving the four economic freedoms priority over other constitutionally protected interests has a principal dimension. There are a few decisions that go in another direction, but they have not yet indicated a fundamental change. Thus, it is true that the CJEU took the special importance that Germany attributes to dignity into account in Omega and found that it could support an exception to free movement. However, it did so after balancing the economic freedoms against dignity, which means that in a different situation, balancing may lead to another result. ${ }^{287}$ In European Arrest Warrant II the BVerfG insisted that the absolute character of dignity is part of the identity of the Basic Law and is thus not negotiable. ${ }^{288}$

The most important impediment to a more balanced approach by the CJEU is its self-image as the superior guardian of the process of integration, whereas the Member States are seen as potential opponents to integration. At the same time, this impediment is the most difficult one to change. It cannot be changed by legal rules but only by a re-orientation of the role that the Court attributes to itself, for which little indication can be seen.

As a matter of fact, the national courts are the only effective counterweights against the CJEU. ${ }^{289}$ It is therefore understandable that some of them reserve the right to adjudicate on ultra vires matters vis-à-vis a European Court that contributes to the creeping loss of competences of the Member States and pays rather little attention to the identities of the national constitutions, as Art. 4 TEU requires.

\footnotetext{
${ }^{287}$ See Sect. 2.2.1 above.

${ }^{288}$ BVerfG, case 2 BvR 2735/14, European Arrest Warrant II, judgment of 15 December 2015.

${ }^{289}$ See Grimm 2012.
} 
One source of the CJEU's dominant role is little noticed: it is the constitutionalisation of the Treaties, yet a constitutionalisation of a body of law that is to a large extent not constitutional in nature, but would be ordinary law in the Member States. Because of this, the EU is over-constitutionalised, to the effect that the jurisprudence of the Court is immunised against corrections by the legislator. It would be an important step towards a better balance between the political branches of the EU and the CJEU to downgrade all provisions of the Treaties that are not of a constitutional nature. ${ }^{290}$

2.13.3 The style of judgments practiced by the CJEU is a good example for the importance of path dependency. The Court started its work in the mode of the French courts, which is particularly cryptic. French courts tell the result of the legal examination and mention the provisions from which the result flows, but do not tell the reader how it flows from them, let alone what alternatives existed and why they were regarded as being inferior to the interpretation chosen by the court. This has changed in the jurisprudence of the CJEU over time, but it is not a change towards the more discursive style of, for example, the German Constitutional Court or even more so of an American or English court. The CJEU answers the questions referred to it by the national courts, but it rarely enters into a discussion of the concerns that motivated the national courts to ask for a preliminary ruling.

The most recent example is the answer of the CJEU to the BVerfG's questions about the compatibility of the OMT with the Treaties. ${ }^{291}$ The BVerfG presented its understanding of the treaty in a very thorough and well thought-out way. The CJEU's answer does not reveal an in-depth examination of the considerations of the BVerfG. The question here is not whose argument is right or wrong, but how to deal with the concerns of national courts. Many referrals from national courts are an invitation to enter into the much invoked dialogue among the courts. Yet a dialogue presupposes a non-hierarchical relationship. This is not the CJEU's understanding of its role. Again, this is difficult to change because it is the result of a certain self-image that can only be changed from within, not from outside.

2.13.4 The role of national constitutions has to be seen in context with the EU's special form of legitimation. What has now become the EU received its democratic legitimacy in the beginning exclusively from the Member States and their democratically organised political processes. The Member States were the 'Masters of the Treaties' and, in the Council, the sole legislator of the EU. But they soon lost control over the interpretation and application of the Treaties. Through the 'constitutionalisation' of the Treaties, the European institutions charged with treaty implementation had made themselves independent from the will of the Member States (see also 2.13.2 and 1.5.3). From that moment on, two paths toward integration existed, a formal one by an explicit transfer of national powers to the EU and an informal one by extensive treaty interpretation based on the judicially

${ }^{290}$ See Grimm 2015a, 2016a. In English, see Grimm 2017.

${ }^{291}$ Case C-62/14 Gauweiler and Others, n. 268. 
invented direct effect, supremacy and 'effet utile'. The first path is political. It can only be tread by the Member States unanimously in accordance with their constitutions and national democratic processes. The second path is non-political and can be tread by the Commission and the CJEU irrespective of the national constitutions. It bypasses the democratic process in the Member States and also the European Parliament.

When the then twelve Member States concluded the Single European Act that allowed for majority decisions in the Council, the exclusive legitimation by the democratic processes in the Member States was no longer sufficient because it could now happen that a Member State was submitted to (secondary) European law that it had not agreed to in its domestic democratic process. This legitimacy gap was closed by the involvement of the - meanwhile directly elected - European Parliament into the making of secondary European law. From that moment on, the EU has been based on a dualist instead of a monistic legitimacy. This additional and autonomous legitimation works, however, only for the enactment of secondary law. It is unable to lend democratic legitimacy to the results of the second path towards integration. The constitutionalisation of the Treaties deprived the democratically legitimated and accountable organs both in the EU and the Member States from influencing the integration through treaty adjudication.

However, this becomes a problem only because of the special character of the Treaties. Concluded as treaties under international law, not as a constitution, the European Treaties are not confined to rules of a constitutional nature, but are full of what would be ordinary law in the Member States. Thus, the functioning of the single market is more or less determined by the interpretation and application of the Treaties (especially the four economic freedoms) by the European executive and judiciary. Here lies an often overlooked source of the European legitimacy problem. Important steps towards integration that left deep marks on the law of the Member States, their constitutions and the range of their political processes have been taken in a non-political mode and by stealth. They are neither subject to political participation nor are they amenable to political correction or re-direction. To the same extent, the source of democratic legitimacy that the EU receives from the constitutional processes in the Member States has been blocked.

However, the hetero-legitimation by the Member States is still much stronger than the auto-legitimation of the EU by the election of the European Parliament. The European Parliament and the European political parties operating within it are not embedded in a Europe-wide societal process of opinion formation and interest articulation that would keep the EU organs in touch with the citizenry. Since the legitimacy of the EU thus depends largely on the flow of legitimation from the Member States, it should have a strong self-interest in a vibrant national democracy. The attempt to solve the European legitimacy problem by extending the powers of the European Parliament or even by converting the EU into a parliamentary system according to the national pattern would provoke just the opposite. As one cannot turn the EU into a parliamentary democracy without downgrading the Council to a second house of the Parliament, one would sever the EU from the legitimation that 
flows from the Member States without having sufficient resources for a European self-legitimation.

Rather, an effective means of increasing the legitimacy of the EU would consist in reducing the Treaties to those provisions that are of a constitutional nature and downgrading all provisions which would be ordinary law in the Member States to the rank of secondary law. As a consequence, the jurisprudence of the CJEU would be subject to a re-direction by way of legislation if the Member States were to find it not to be in line with their understanding of the Treaties or were to think that it produces detrimental effects. As long as this has not happened - and it is rather unlikely that it will happen - the national constitutions and their agents, the national constitutional courts, are the only counterweights to the democracy drain in the Member States and the ensuing repercussions on the legitimacy of the European Union - and also the only guardians of the democratic potential for Europe that lies in the national constitutions. They act in the interest of European democracy when they claim the power to protect the identity of the national constitutions. Article 4 (2) TEU justifies this claim. ${ }^{292}$

\section{Constitutional Issues in Global Governance}

\subsection{Constitutional Rules on International Organisations and the Ratification of Treaties}

3.1.1 Understandably, after the catastrophe caused by an excessive nationalism, the German Basic Law from the very beginning in 1949 was open to an internationalisation of public power. Already the preamble spoke of an integrated Europe as a contribution to peace in the world. Article 24 permitted the transfer of public powers to international organisations. It also permitted Germany to join systems of collective security and to transfer public powers in order to guarantee a peaceful and sustainable order, European as well as global. International arbitration was welcomed. $^{293}$

${ }^{292}$ For a more detailed argumentation, see Grimm (2016b). See also Grimm 2012, especially p. 92 (Die Bedeutung nationaler Verfassungen in einem vereinten Europa) and p. 128 (Zur Rolle der nationalen Verfassungsgerichte in der europäischen Demokratie).

293 Art. 24 reads:

'(1) The Federation may by a law transfer sovereign powers to international organisations.

(1a) Insofar as the Länder are competent to exercise state powers and to perform state functions, they may, with the consent of the Federal Government, transfer sovereign powers to transfrontier institutions in neighbouring regions.

(2) With a view to maintain peace, the Federation may enter into a system of mutual collective security; in doing so it shall consent to such limitations upon its sovereign powers as will bring about and secure a lasting peace in Europe and among the nations of the world.

(3) For the settlement of disputes between states, the Federation shall accede to agreements providing for general, comprehensive and compulsory international arbitration.' 
Article 25 transformed the general principles of public international law into domestic law and gave them a rank above ordinary law. ${ }^{294}$ At the same time Art. 25 stated that these principles established direct rights and obligations for the residents. Article 26 declared attempts to wage aggressive wars unconstitutional and required that they be criminalised. The export of weapons was made dependent on a permission from the Federal Government.

3.1.2 When the Maastricht treaty transformed the European Community into the European Union and declared that this treaty 'marks a new stage in the process of creating an ever closer union among the peoples of Europe', Art. 24, up to then the constitutional basis for Germany's participation in European integration, seemed no longer sufficient to legitimise the unprecedented process of creating a political entity that by far exceeded traditional international organisations. The need for a special rule concerning European integration was felt. Thus, the new Art. 23 was adopted in 1992; it is outlined in Sect. 1.2.

3.1.3 After the 1992 amendment, the first sentence of Sect. 6 was reformulated in 2006 in connection with a reform of the federal system; Sect. 1 a was added in 2008 to adjust the Basic Law to the Lisbon Treaty (see text under 1.2.1). No significant proposals for further reform have been made. It has been up to the BVerfG to concretise and develop the provisions in the light of new developments.

3.1.4 The new world order that emerged after World War II brought the identity between public power and state power to an end. In the interest of preserving peace and increasing their problem solving capacity, the states transferred parts of their authority to international organisations that exercise it more or less independently from the states, but with legal effect within them. However, the states neither disappeared nor were they marginalised. They remain the main actors also in the new international order. They convey legitimacy on the public power exercised by international organisations whose own legitimacy resources are small.

While a legalisation of the power exercised beyond the state is possible and rapidly growing, its democratisation seems much more difficult. The more global international organisations are, the less democratic they will be. The same is true for a constitutionalisation of international organisations and international law in general. Where the term 'constitutionalisation' is used in this context, it reflects a rather thin concept of constitutionalism, a mere legalisation rather far away from the achievement of constitutionalism as it developed over time in the nation states.

Although state constitutions can no longer fulfil their promise to regulate the public authority exercised on the territory of the state in a comprehensive way, they still have to play an important role. They regulate the national political process, determine the transfer of state powers to the international level and define the conditions under which acts of international organisations and international law

\footnotetext{
${ }^{294}$ Art. 25 reads: 'The general rules of international law shall be an integral part of federal law. They shall take precedence over the laws and directly create rights and duties for the inhabitants of the federal territory.'
} 
may take effect within the state. Since the internationally exercised public power depends on authorisation, acceptance and implementation by the states, international organisations should have a self-interest in the good functioning of national constitutionalism instead of eroding it. ${ }^{295}$

\subsection{The Position of International Law in National Law}

3.2.1 The provisions of the Basic Law concerning international treaties are rudimentary. Article 59(1) gives the Federal President the power to conclude international treaties. Article 59(2) prescribes that international treaties regulating the political relations of the Federal Republic or concerning legislative competences need the consent of the Bundestag in the form of a law. This law (Zustimmungsgesetz) is confined to consent and does not contain legal provisions. The object of the consent follows from the treaty.

In practice, international treaties are negotiated by the Federal Government, ratified by the Federal President and made binding by a decision of the Bundestag. It is contested whether parliamentary consent transforms the treaty provisions into domestic law or only gives the order that they be applied internally. There are no provisions as to the rank of international treaties in the domestic legal order. It is therefore up to the legislature to determine the rank. It is beyond doubt that the BVerfG can review the parliamentary consent to a treaty as to its compatibility with the Basic Law. Applications for review are admissible before the treaty becomes valid under international law.

3.2.2 Regarding the relevance of monism/dualism, this has been a controversy for a long time. However, the controversy has lost importance. Today, the majority of authors accept a theory of moderate dualism. According to this theory, each body of law exists of its own right, but both are in many ways interwoven. On the one hand, international law (including European law) takes effect within the state only insofar as the state transforms it into domestic law or orders its application within the state. On the other hand, more and more international law claims direct effect in the states. To the same extent, international organisations and international courts take the lead. With regard to the EU, it is assumed that the states are the 'Masters of the Treaties' only at the moment of conclusion, but no longer when treaty provisions are implemented and enforced. A change of the CJEU's practice in interpreting and implementing treaty provisions would require an amendment to the Treaties. Since this is extremely difficult to achieve, the CJEU is immunised against being re-directed by legislation. This is a consequence of the constitutionalisation of the Treaties (see Sect. 2.13.4).

${ }^{295}$ For more details, see Grimm 2010 and 2015a, b. 


\subsection{Democratic Control}

3.3.1 In general, parliaments are the losers in the internationalisation of the law. They do not participate in negotiation on the international level. Negotiation is a matter for the executive. In some countries the executive has but a limited mandate and needs the approval of Parliament if it wants to go beyond this limit. But many countries find that this threatens to fetter the national Government, so that it cannot be fully effective in negotiations where a do ut des is unavoidable. Parliaments are, of course, free to reject a treaty that the Government has negotiated, but in a parliamentary system this would mean that the parties supporting the Government would disapprove of their own leadership, and consequently parliamentary refusal is rare. Rather, the importance of Parliament's involvement lies in its anticipatory effect. Governments will hesitate to risk disapproval and therefore take the position of Parliament into account when negotiating on the international level.

In Germany, the BVerfG has constantly strengthened the role of the Bundestag in foreign affairs. Thus, the deployment of the German army outside of NATO was made dependent on a parliamentary vote. ${ }^{296}$ In matters European, the BVerfG assumes a parliamentary responsibility for the extent and direction of integration as well as for the organisational and procedural arrangement on the European level (Integrationsverantwortung), which it cannot delegate to the executive. ${ }^{297}$ Usually this leads to intensive parliamentary debates. Since the Bundestag can exercise its responsibility only if it has full information of the subject matter and sufficient time to study it and form an opinion, the Government is under a constitutional duty to provide the information early and comprehensively. ${ }^{298}$ However, it turns out that in practice the capacity of Parliament to cope with the flood of information is limited. The jurisprudence thus tries to erect a bulwark against a trend that is more or less unstoppable.

3.3.2 The Basic Law provides for referendums only in connection with a redefinition of the borders of the Länder. With regard to referendums regarding European integration, including the requirement by the BVerfG that a new constitution would have to be adopted by referendum to participate in a European state, see Sect. 1.4.2.

\footnotetext{
${ }^{296}$ BVerfG, case 2 BvE 3/92 et al., Out-of-Area Operations, judgment of 12 July 1994, BVerfGE $90,286$.

${ }^{297}$ BVerfG, case 2 BvE 2/08 et al., Treaty of Lisbon, judgment of 30 June 2009, BVerfGE 123, 267,356 et seq.

${ }^{298}$ Concretized in BVerfG, case 2 BvE 4/11, Obligation to Provide Information, judgment of 18 June 2012, BVerfGE 131, 152.
} 


\subsection{Judicial Review}

3.4.1 International treaties and measures under international law (acts exercising powers transferred by treaties) should be distinguished.

In Germany, international treaties are subject to judicial review via the law that expresses the consent of Parliament (Zustimmungsgesetz). At this stage the national Constitution functions as a filter for the obligations that Germany takes on by concluding a treaty. ${ }^{299}$ Treaties that confer competences to international organisations change, by this very fact, the Constitution without explicitly amending the text. This is why a supermajority is required for such treaties. Thus, the constitutional constraints become relevant already in the process of negotiation, because the Government has to face a review by the BVerfG. The BVerfG has full power to review the compatibility of a treaty with the Basic Law and, unlike in the review of domestic laws which can only be reviewed after having been adopted and after having taken legal force, treaties can be reviewed before they become valid law.

Once powers have been transferred to international organisations, their exercise by these organisations no longer follows the national constitution. But this does not mean that the national constitution is completely irrelevant. The fact that a treaty itself is compatible with the national constitution does not automatically guarantee that acts or measures taken under the treaty are compatible with the constitution. Two constellations are possible: the international organisation acts ultra vires or it acts within the limits of transferred powers, but the concrete act or measure is incompatible with some essential features of the national constitution.

The BVerfG has reacted to both possibilities. It reserves the power of an ultra vires control, regardless of whether the international organisation has developed an internal control mechanism such as the CJEU. ${ }^{300}$ It is not controversial that the CJEU has the power to review Union acts as to their compatibility with the Treaty. But the CJEU denies national constitutional courts the right to do the same. However, both view it from a different angle. While the international court asks whether the international organisation has received a competence, the national constitutional court asks whether the Member State has transferred that power. Since the object of judicial scrutiny is the same for both courts, namely the text of the treaty, this is a source of conflict. The BVerfG has tried to narrow this source by a self-limitation of its review power. It will declare Union acts inapplicable in Germany only if they obviously violate the Treaties and they in addition produce a

\footnotetext{
${ }^{299}$ See Grimm 2012, pp. 92-127.

${ }^{300}$ BVerfG, case 2 BvR 2134, 2159/92, Treaty of Maastricht, judgment of 12 Oct. 1993, BVerfGE 89, 155, 171 et seq.; confirmed in BVerfG, case 2 BvE 2/08 et al., Treaty of Lisbon, judgment of 30 June 2009, BVerfGE 123, 267, 352 et seq.
} 
power shift from the Member States to the Union. Further, it will use its power only after having referred the question of a treaty violation to the CJEU. ${ }^{301}$

The other alternative, international acts that are not ultra vires but adversely affect the very essence of the national Constitution, is the object of the Solange jurisprudence. In Solange I the BVerfG declared that fundamental rights protection is part of the core values of the Basic Law. As long as no equivalent protection exists on the international level, the BVerfG will review international acts as to their compatibility with domestic fundamental rights. ${ }^{302}$ This jurisprudence is still valid. In Solange II the Court did not give up its power but only declared that it would no longer exercise it, as long as a sufficient protection of fundamental rights exists on the European level. This has been confirmed by the Lisbon judgment and extended from fundamental rights to other essential elements of the national constitution. The judgment European Arrest Warrant II specified that international (including European) law which contradicts the identity of the Basic Law as guaranteed by Art. 79(3) is not applicable in Germany under any condition.

A slightly different attitude has been developed vis-à-vis judgments of the ECtHR. This court may review national acts as to their compatibility with the European Convention and declare them in violation of the Convention. But its judgments lack direct effect within the member states. The state is under an obligation to remedy the violation. This is usually the task of the national court whose decision violated the Convention. The decisions of the national courts are subject to judicial review by the BVerfG. The leading case is Görgülü. ${ }^{303}$ The BVerfG ruled that national courts have to take decisions of the ECtHR into account but are not unconditionally obliged to follow them. Since Germany adopted the Convention in the rank of ordinary law, no judgment of the ECtHR is internally binding that is incompatible with the Basic Law. But the BVerfG at the same time requires an attempt to reconcile the interpretation of the Basic Law with the interpretation of the Convention. Good examples are the Caroline cases. ${ }^{304}$ Regarding ordinary law, the national courts, according to the BVerfG, are under an obligation to examine whether the European jurisprudence can be integrated into the national law. The detailed account on the internal effect of public international law and the review power of the BVerfG can now be found in a case on the Tax Treaty between Germany and Turkey. ${ }^{305}$

\footnotetext{
${ }^{301}$ BVerfG, case 2 BvR 2661/06, Honeywell, order of 6 July 2010, BVerfGE 126, 286.

302 BVerfG, case 2 BvL 52/71, Solange I, order of 29 May 1974, BVerfGE 37, 271.

${ }^{303}$ BVerfG, case 2 BvR 1481/04, Görgülü, order of 14 Oct. 2004, BVerfGE 111, 307.

${ }^{304}$ BVerfG, case 1 BvR 653/96, Caroline von Monaco II, judgment of 15 Dec. 1999, BVerfGE 101, 361; ECtHR Von Hannover v. Germany, no. 59320/00, ECHR 2004-VI; BVerfG, case 1 BvR 1602/07 et al., Caroline von Monaco III, order of 26 Feb. 2008, BVerfGE 120, 180.

${ }^{305}$ BVerfG, case 2 BvL 1/12, Tax Treaty, judgment of 15 December 2015.
} 


\subsection{The Social Welfare Dimension of the Constitution}

3.5.1 With regard to the social state, there is indeed constant concern in Germany, a state with a rather high degree of social security, which was an important element for the legitimacy of the political system. It is seen as a problem that economic policy and social policy are decoupled in Europe, at the expense of social interests. On the global level, it is seen as a problem that global economic discourses and human rights discourses have developed independently of each other.

\section{References}

Ahlbrecht H., Lagodny O. (2003) Einheitliche Strafverfahrensgarantien in Europa? Strafverteidiger Forum 10:329-335.

Ambos K., König S., Rackow P. (eds.) (2015) Rechtshilferecht in Strafsachen. Nomos, Baden-Baden.

Ambos K., Poschadel A. M., § 73 IRG - Grenzen der Rechtshilfe. In: Ambos K., König S., Rackow P. (eds.) (2015), pp. 82-95.

Barak A. (2012) Proportionality. Cambridge University Press, Cambridge.

Böse M. (ed.) (2013) Enzyklopädie Europarecht, Band 9: Europäisches Strafrecht. Nomos, Baden-Baden.

Böse M. (2014) Vor $\S 78$; $\S 83$ IRG. In: Grützner H., Pötz P. G., Kreß C. (eds.) Internationaler Rechtshilfeverkehr in Strafsachen, 3rd edn. C.F. Müller, Heidelberg.

Braum S. (2009) Europäisches Strafrecht im Fokus konfligierender Verfassungsmodelle. Zeitschrift für Internationale Strafrechtsdogmatik (ZIS) 8:418-426.

Britz G. (2015) Grundrechtsschutz durch das Bundesverfassungsgericht und den Europäischen Gerichtshof. Europäische Grundrechte-Zeitschrift (EuGRZ) 42:275-281.

Brodowski D. (2013) Europäischer ordre public als Ablehnungsgrund für die Vollstreckung Europäischer Haftbefehle? Höchstrichterliche Rechtsprechung in Strafsachen (HRRS) 2:5456.

Burchard C. (2013) Auslieferung (Europäischer Haftbefehl). In: Böse M. (ed.) (2013) Enzyklopädie Europarecht, Band 9: Europäisches Strafrecht. Nomos, Baden-Baden, pp. 537-572.

Classen C.D. (2007) Verbesserung der Europatauglichkeit. In: Starck C. (ed.) Föderalismusreform. C. H. Beck, Munich, pp. 103 et seq.

Classen C.D. (2010), Artikel 23. In: v Mangoldt H., Klein F., Starck C. (eds.), Kommentar zum Grundgesetz, volume 2, $6^{\text {th }}$ edn. C.H. Beck, Munich.

Conrad P. (2013) Der Grundsatz der beiderseitigen Strafbarkeit im Rechtshilfe- und Strafanwendungsrecht. Kovac, Hamburg.

Currie D.P. (1994) The Constitution of the Federal Republic of Germany. The University of Chicago Press, Chicago.

Davis D., Richter R., Saunders C. (eds.) (2015) An Inquiry into the Existence of Global Values: Through the Lens of Comparative Constitutional Law. Hart, Oxford.

Deiters M. (2003) Gegenseitige Anerkennung von Strafgesetzen in Europa. Zeitschrift für Rechtspolitik (ZRP) 10:359-362.

Dreier H. (2007) Grundlagen und Grundzüge staatlichen Verfassungsrechts: Deutschland. In: von Bogdandy A., Cruz Villalón P., Huber P. (eds.) Ius Publicum Europaeum, volume I. C.F. Müller, Heidelberg, pp. 3-85.

Eberhard F. (1948) Redebeitrag in Parlamentarischer Rat, Verhandlungen des Hauptausschusses. 
Everling U. (2010) Europas Zukunft unter der Kontrolle der nationalen Verfassungsgerichte. Europarecht 45:91-107.

Franzius C. (2015a) Strategien der Grundrechtsoptimierung in Europa. Europäische Grundrechte-Zeitschrift (EuGRZ) 42:139-153.

Franzius C. (2015b) Grundrechtsschutz in Europa. ZaöRV Heidelberg Journal of International Law (HJIL) 75:383-412.

Gaede K. (2013) Minimalistischer EU-Grundrechtsschutz bei der Kooperation im Strafverfahren. Neue Juristische Wochenschrift (NJW) 18:1279-1282.

Gärditz K., Hillgruber C. (2009) Volkssouveränität und Demokratie ernst genommen - Zum Lissabon-Urteil des BVerfG. Juristenzeitung (JZ) 64:872 et seq.

Gleß S. (2004) Zum Prinzip der gegenseitigen Anerkennung. Zeitschrift für die gesamte Strafrechtswissenschaft (ZStW) 116:353-367.

Grimm D. (2007) Proportionality in Canadian and German Constitutional Jurisprudence. U. Toronto L.J. 57:383-397.

Grimm D. (2009) Defending Sovereign Statehood against Transforming the European Union into a State. EuConst 5:353-373.

Grimm D. (2010) The Achievement of Constitutionalism and its Prospects in a Changed World. In: Dobner P. and Loughlin M. (eds.) The Twilight of Constitutionalism. Oxford University Press, Oxford, pp. 3-22.

Grimm D. (2012) Die Zukunft der Verfassung II. Suhrkamp, Berlin.

Grimm D. (2015a) The Democratic Costs of Constitutionalization - The European Case. ELJ 21:460-473.

Grimm D. (2015b) The Role of Fundamental Rights after 65 Years of Constitutional Jurisprudence in Germany. ICON 13:9-29.

Grimm D. (2015c) Sovereignty. Columbia University Press, New York.

Grimm D. (2016a) Europa ja - aber welches? Zur Verfassung der europäischen Demokratie. Beck, Munich.

Grimm D. (2016b) Constitutionalism: Past, Present, and Future. Oxford University Press, Oxford.

Grimm D. (2017) The Constitution of European Democracy. Oxford University Press, Oxford.

Habermas J. (1992) Faktizität und Geltung. Suhrkamp, Frankfurt. (reprint 1998).

Hackner T. (2005) Der Europäische Haftbefehl in der Praxis der Staatsanwaltschaften und Gerichte. Neue Zeitschrift für Strafrecht (NStZ) 6:311-315.

Hackner T. (2012) § 78 IRG - Vorrang des Achten Teils; § 79 IRG - Grundsätzliche Pflicht zur Bewilligung; § 83 IRG - Ergänzende Zulässigkeitsvoraussetzungen. In: Schomburg W., Lagodny O., Gleß S., Hackner T. (eds.) (2012) Internationale Rechtshilfe in Strafsachen, 5th edn. C.H. Beck, Munich, pp. 462-474; 482-486.

Halberstam D., Möllers C. (2009) The German Constitutional Court says 'Ja zu Deutschland!' German Law Journal (GLJ) 10:1241-1258.

Hecker B. (2015) Europäisches Strafrecht. $5^{\text {th }}$ edn. Springer, Berlin.

Heger M. (2007) Der europäische Haftbefehl: Zur Umsetzung europäischer Vorgaben in Deutschland. Zeitschrift für Internationale Strafrechtsdogmatik (ZIS) 5:221-225.

Heger M., Wolter K. (2015) Rahmenbeschluss über den Europäischen Haftbefehl und dessen Umsetzung im IRG. In: Ambos K., König S., Rackow P. (eds.) (2015), pp. 324-374.

Hoffmann R. (2007) Europafähigkeit der Bundesrepublik. In: Holtschneider R., Schön W. (eds.), Die Reform des Bundesstaates. Nomos, Baden-Baden, pp. 225 et seq.

Inhofer D. (2015) § 79 IRG - Grundsätzliche Pflicht zur Bewilligung; § 83 IRG - Ergänzende Zulässigkeitsvoraussetzungen. In: Graf J.P. (ed.) (2015) Beck'scher Online Kommentar Strafprozessordnung, $23^{\text {rd }}$ edn. C.H. Beck, Munich.

Jestaedt M. (2009) Warum in die Ferne schweifen, wenn der Maßstab liegt so nah? Verfassungshandwerkliche Anfragen an das Lissabon-Urteil des BVerfG. Der Staat 48:497516.

Jestaedt M., Lepsius O., Möllers C., Schönberger C. (2011) Das entgrenzte Gericht - Eine kritische Bilanz nach sechzig Jahren Bundesverfassungsgericht. Suhrkamp, Berlin. 
Kaufmann E. (1953) Rechtsgutachten zum Vertrage über die Gründung der Europäischen Verteidigungsgemeinschaft und zum Deutschlandvertrage. In: Institut für Staatslehre und Politik Mainz (ed.) Der Kampf um den Wehrbeitrag, volume II. Isar-Verlag, Munich, pp. 42 et seq.

Kirchhof P. (1991) Deutsches Verfassungsrecht und Europäisches Gemeinschaftsrecht. In: Kirchhof P., Ehlermann C.-D. (eds.) Deutsches Verfassungsrecht und Europäisches Gemeinschaftsrecht. Europarecht Beiheft 1/1991, Baden-Baden, pp. 11 et seq.

König D. (1994) Das Urteil des Bundesverfassungsgerichts zum Vertrag von Maastricht - ein Stolperstein auf dem Weg in die europäische Integration? Zeitschrift für ausländisches öffentliches Recht und Völkerrecht 54:17-49.

König D. (2000) Die Übertragung von Hoheitsrechten im Rahmen des europäischen Integrationsprozesses - Anwendungsbereich und Schranken des Art. 23 des Grundgesetzes. Duncker \& Humblot, Berlin.

Lagodny O. (2014) § 22 - Transnationales Strafverfahren. In: Widmaier G., Müller E., Schlothauer R. (eds.) Münchener Anwaltshandbuch Strafverteidigung, $2^{\text {nd }}$ edn. C.H. Beck, Munich, pp. 826-845.

Lorz R., Sauer H. (2012) Verfassungsändernde Mehrheiten für die Stabilisierung des Euro? Europarecht 47:682-695.

Masing J. (2015) Einheit und Vielfalt des Europäischen Grundrechtsschutzes. JZ 70:477-487.

Mayer F. (2000) Kompetenzüberschreitung und Letztentscheidung. C.H. Beck, Munich.

Mayer F. (2004) Europarecht als französisches Verfassungsrecht. Europarecht 39:925-936.

Mayer F. (2010) Europarechtsfreundlichkeit und Europarechtsskepsis in der Rechtsprechung des Bundesverfassungsgerichts. In: Giegerich T. (ed.) Der 'offene Verfassungsstaat' des Grundgesetzes nach 60 Jahren. Duncker \& Humblot, Berlin, pp. 237-271.

Mayer F. (2011) Rashomon in Karlsruhe: A reflection on democracy and identity in the European Union. ICON 9:757-785.

Mayer F., Wendel M. (2014) Die verfassungsrechtlichen Grundlagen des Europarechts. In: Hatje A., Müller-Graff P.-C. (eds.) Enzyklopädie Europarecht, volume 1. Nomos, Baden-Baden, $\S 4$.

Müller J.W. (2010) Verfassungspatriotismus. Suhrkamp, Berlin.

Nettesheim M. (2010) Die Karlsruher Verkündigung - Das BVerfG in staatsrechtlicher Endzeitstimmung. Europarecht Beiheft 2010 1:101-122.

Nusser J. (2011) Die Bindung der Mitgliedstaaten an die Unionsgrundrechte. Mohr Siebeck, Tübingen.

Pernice I. (1999) Multilevel Constitutionalism and the Treaty of Amsterdam: European Constitution-Making Revisited? CML Rev. 36:703-750.

Pernice I. (2006) Artikel 23. In: Dreier H. (ed.) Grundgesetz Kommentar, volume 2, $2^{\text {nd }}$ edn. Mohr Siebeck, Tübingen.

Pernice I. (2007) Artikel 23. In: Dreier H. (ed.) Grundgesetz Kommentar, volume 2. $2^{\text {nd }}$ edn. Supplementum 2007, Mohr Siebeck, Tübingen.

Pernice I. (2009) The Treaty of Lisbon: Multilevel Constitutionalism in Action. Columbia Journal of European Law 15:349 et seq.

Ranft O. (2005) Die Verfassungswidrigkeit des (deutschen) Europäischen Haftbefehlsgesetzes. Zeitschrift für Wirtschafts- und Steuerstrafrecht 10:361-368.

Reinbacher T. (2014) Strafrecht im Mehrebenensystem. Nomos, Baden-Baden.

Robertson D. (2010) The Judge as Political Theorist: Contemporary Constitutional Review. Princeton University Press, Princeton.

Satzger H. (2012) International and European Criminal Law. C.H. Beck, Munich.

Schmalenbach K. (1996) Der neue Europaartikel 23 des Grundgesetzes im Lichte der Arbeit der Gemeinsamen Verfassungskommission. Duncker \& Humblot, Berlin.

Schneider K. (2014) Questions and Answers: Karlsruhe's Referral for a Preliminary Ruling to the Court of Justice of the European Union. German Law Journal (GLJ) 15:217-239.

Schönberger C. (2009) Lisbon in Karlsruhe: Maastricht's Epigones At Sea. German Law Journal (GLJ) 10:1201-1218. 
Schorkopf F. (2009) The European Union as an Association of Sovereign States: Karlsruhe's Ruling on the Treaty of Lisbon. German Law Journal (GLJ) 10:1219-1240.

Schultze-Fielitz H. (2013) Staatsrechtslehre als Mikrokosmos. Mohr Siebeck, Tübingen.

Schünemann B. (2003) Europäischer Haftbefehl und EU-Verfassungsentwurf auf schiefer Ebene Die Schranken des Grundgesetzes. Zeitschrift für Rechtspolitik (ZRP) 6:185-189.

Schünemann B. (ed.) (2004) Alternativentwurf Europäische Strafverfolgung. Carl Heymanns, Köln.

Schünemann B. (2007) Europäischer Sicherheitsstaat = europäischer Polizeistaat? Zeitschrift für Internationale Strafrechtsdogmatik (ZIS) 14:528-534.

Schwarze J. (2010) Die verordnete Demokratie. Europarecht 1:108-117.

Sinn A., Wörner L. (2007) The European Arrest Warrant and Its Implementation In Germany - Its Constitutionality, Laws and Current Developments. Zeitschrift für Internationale Strafrechtsdogmatik (ZIS) 5:204-220.

Sommermann K.P. (1997) Staatsziele und Staatszielbestimmungen. Mohr Siebeck, Tübingen.

Sommermann K.P. (2008) Offene Staatlichkeit - Deutschland. In: von Bogdandy A., Cruz Villalón P., Huber P. (eds.) Ius Publicum Europaeum, volume II. C. F. Müller, Heidelberg, pp. 3-35.

Sternberger D. (1990) Verfassungspatriotismus. Insel Verlag, Frankfurt.

Streinz R. (2014) Artikel 23. In: Sachs M. (ed.) Grundgesetz: Kommentar, 7th edn. C.H. Beck, Munich.

Thym D. (2009) In the Name of Sovereign Statehood: A Critical Introduction to the Lisbon Judgment of the German Constitutional Court. CML Rev. 46:1795-1822.

Thym D. (2015) Vereinigt die Grundrechte. Juristenzeitung 70: 53 et seq.

Tomuschat C. (1993) Die Europäische Union unter der Aufsicht des Bundesverfassungsgerichts. Europäische Grundrechte-Zeitschrift (EuGRZ) 20:489 et seq.

Tomuschat C. (2009) The Ruling of the German Constitutional Court on the Treaty of Lisbon. German Law Journal (GLJ) 10:1259-1262.

Vogel J. (2014) § 10 IRG - Auslieferungsunterlagen; § 73 IRG - Grenze der Rechtshilfe. In: Grützner H., Pötz P. G., Kreß C. (eds.) (2014) Internationaler Rechtshilfeverkehr in Strafsachen, $3^{\text {rd }}$ edn. C.F. Müller, Heidelberg.

Vogel J., Burchard C. (2014) § 77 IRG - Anwendung anderer Verfahrensvorschriften. In: Grützner H., Pötz P. G., Kreß C. (eds.) (2014) Internationaler Rechtshilfeverkehr in Strafsachen, $3^{\text {rd }}$ edn. C.F. Müller, Heidelberg.

Vogel K. (1964) Die Verfassungsentscheidung des Grundgesetzes für eine internationale Zusammenarbeit. Recht und Staat in Geschichte und Gegenwart 292/293:1 et seq.

Vogler T. (1989) Auslagenerstattung im Auslieferungsrecht. Neue Zeitschrift für Strafrecht (NStZ) 6:254-255.

Von Bogdandy A. (2003) Europäische und nationale Identität: Integration durch Verfassungsrecht? Veröffentlichungen der Vereinigung der Deutschen Staatsrechtslehrer (VVDStRL) 62:156 et seq.

Von Bubnoff E. (2005) Der Europäische Haftbefehl. C.F. Müller, Heidelberg.

Von Heintschel-Heinegg B. (2014) Europäischer Haftbefehl. In: Sieber U., Satzger H., von Heintschel-Heinegg B. (eds.) Europäisches Strafrecht, 2nd edn. Nomos, Baden-Baden, pp. 661-677.

Voßkuhle A. (2010) Multilevel cooperation of the European Constitutional Courts: Der Europäische Verfassungsgerichtsverbund. EuConst 6:175-198.

Wendel M. (2011a) Permeabilität im europäischen Verfassungsrecht. Verfassungsrechtliche Integrationsnormen auf Staats- und Unionsebene im Vergleich. Mohr Siebeck, Tübingen.

Wendel M. (2011b) Lisbon Before the Courts: Comparative Perspectives. EuConst 7:96-137. 
Wendel M. (2013) Judicial Restraint and the Return to Openness: The Decision of the German Federal Constitutional Court on the ESM and the Fiscal Treaty of 12 September 2012. German Law Journal (GLJ) 14:21-52.

Wendel M. (2014) Exceeding Judicial Competence in the Name of Democracy. EuConst 10:263307.

Ziller J. (2003) Sovereignty in France: Getting Rid of the Mal de Bodin. In: Walker N. (ed.) Sovereignty in Transition, Hart Publishing, Oxford, pp. 261-277.

Open Access This chapter is licensed under the terms of the Creative Commons Attribution 4.0 International License (http://creativecommons.org/licenses/by/4.0/), which permits use, sharing, adaptation, distribution and reproduction in any medium or format, as long as you give appropriate credit to the original author(s) and the source, provide a link to the Creative Commons license and indicate if changes were made.

The images or other third party material in this chapter are included in the chapter's Creative Commons license, unless indicated otherwise in a credit line to the material. If material is not included in the chapter's Creative Commons license and your intended use is not permitted by statutory regulation or exceeds the permitted use, you will need to obtain permission directly from the copyright holder. 